Prepared in cooperation with the Federal Emergency Management Agency

\title{
Flood-Inundation Maps of Selected Areas Affected by the Flood of October 2015 in Central and Coastal South Carolina
}

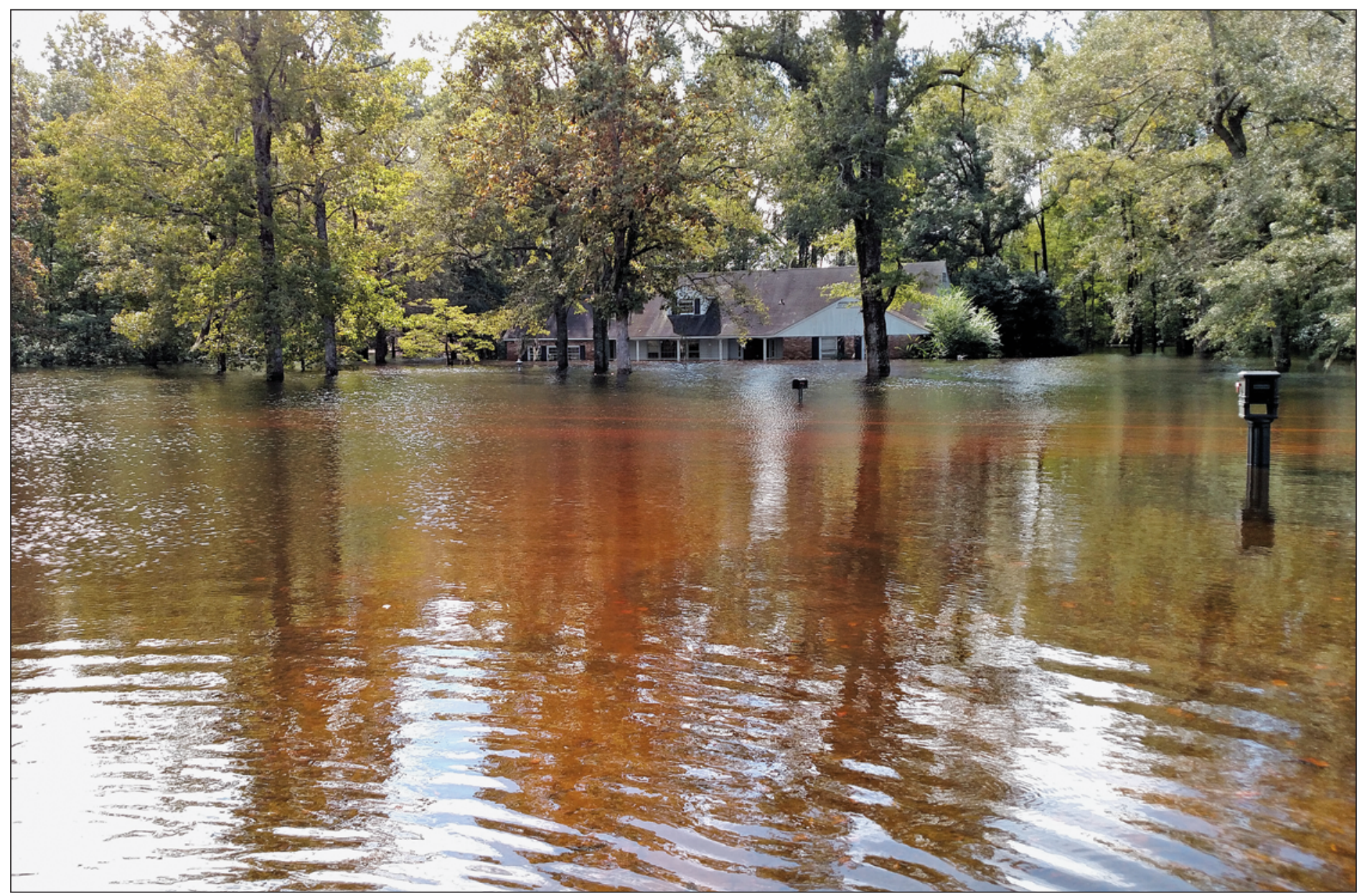

Open-File Report 2016-1019

U.S. Department of the Interior

U.S. Geological Survey 
Cover. Flooded home off Big Dam Swamp Road, Andrews, South Carolina, October 11, 2015. Photograph by Lynn Torak, U.S. Geological Survey. 


\section{Flood-Inundation Maps of Selected Areas Affected by the Flood of October 2015 in Central and Coastal South Carolina}

By Jonathan W. Musser, Kara M. Watson, Jaime A. Painter, and Anthony J. Gotvald

Prepared in cooperation with the Federal Emergency Management Agency

Open-File Report 2016-1019 


\title{
U.S. Department of the Interior SALLY JEWELL, Secretary
}

\section{U.S. Geological Survey \\ Suzette M. Kimball, Director}

\author{
U.S. Geological Survey, Reston, Virginia: 2016
}

For more information on the USGS - the Federal source for science about the Earth, its natural and living resources, natural hazards, and the environment—visit http://www.usgs.gov or call 1-888-ASK-USGS.

For an overview of USGS information products, including maps, imagery, and publications, visit http://www.usgs.gov/pubprod/.

Any use of trade, firm, or product names is for descriptive purposes only and does not imply endorsement by the U.S. Government.

Although this information product, for the most part, is in the public domain, it also may contain copyrighted materials as noted in the text. Permission to reproduce copyrighted items must be secured from the copyright owner.

Suggested citation:

Musser, J.W., Watson, K.M., Painter, J.A., and Gotvald, A.J., 2016, Flood-inundation maps of selected areas affected by the flood of October 2015 in central and coastal South Carolina: U.S. Geological Survey Open-File Report 2016-1019, 81 p., http://dx.doi.org/10.3133/ofr20161019.

ISSN 2331-1258 (online) 


\section{Contents}

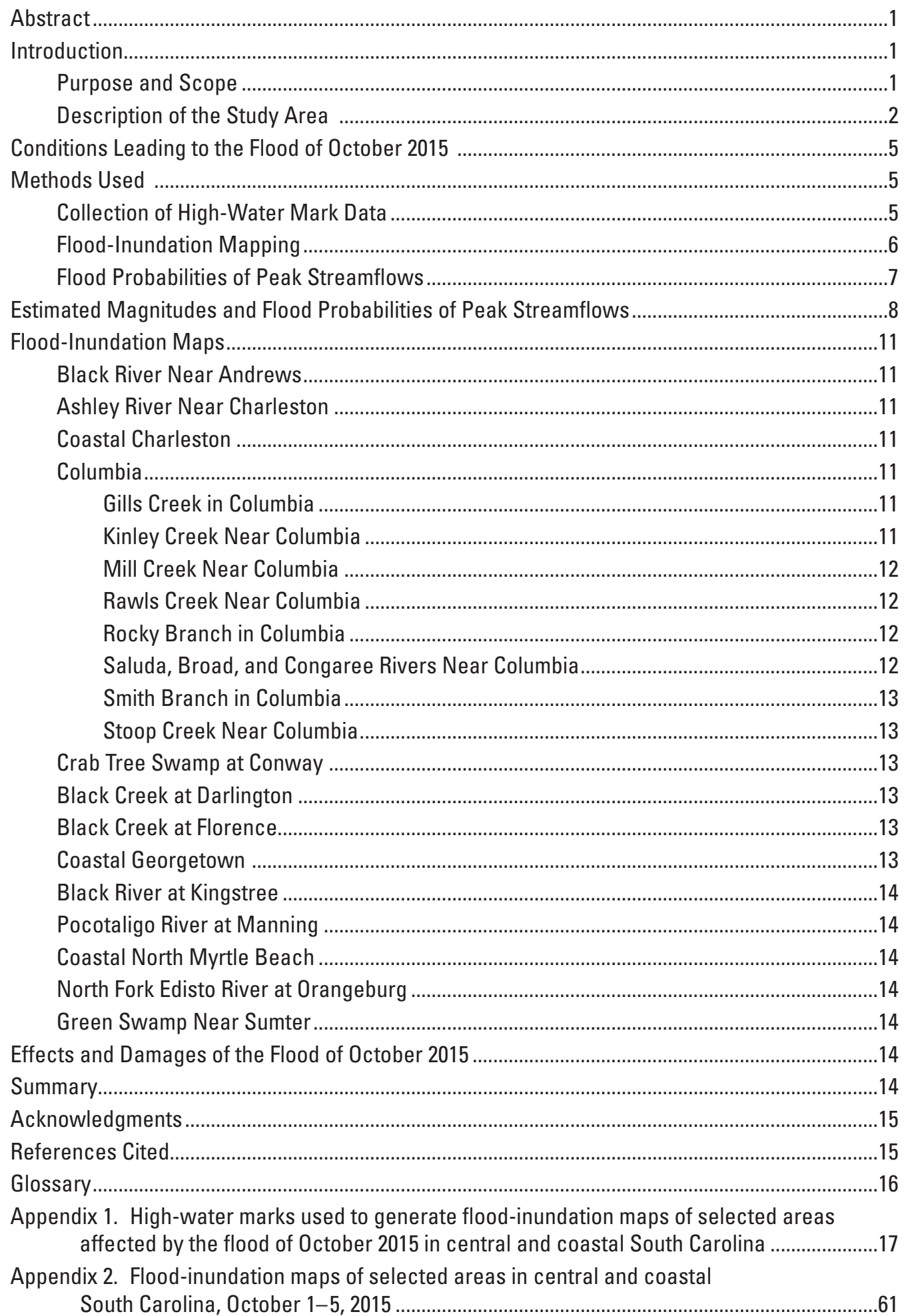




\section{Figures}

1. Infrared satellite image of the intense rainfall in South Carolina during the morning of October 3, 2015

2. Map showing counties in South Carolina with one or more National Weather Service or U.S. Geological Survey rainfall gages recording more than 5 inches of rainfall for October 1-5, 2015, and U.S. Geological Survey streamgages with associated flood-inundation maps.

3. Map showing study area showing location of flood-inundation mapping sites in central and coastal South Carolina...

2-1 to 2-20. Flood-inundation map, South Carolina, October 1-5, 2015, showing-

2-1. Black River near Andrews .........................................................................62

2-2. Ashley River near Charleston ........................................................................63

2-3. Coastal Charleston. .......................................................................................64

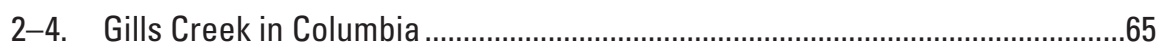

2-5. Kinley Creek near Columbia ....................................................................6

2-6. Mill Creek near Columbia ...............................................................................67

2-7. Rawls Creek near Columbia ............................................................................68

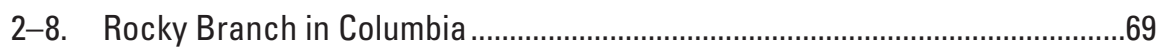

2-9. Saluda, Broad, and Congaree Rivers near Columbia .......................................70

2-10. Smith Branch in Columbia .......................................................................

2-11. Stoop Creek near Columbia .......................................................................

2-12. Crab Tree Swamp at Conway.......................................................................

2-13. Black Creek at Darlington ........................................................................

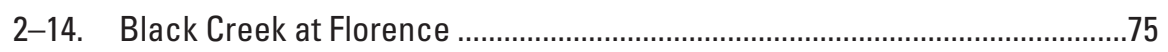

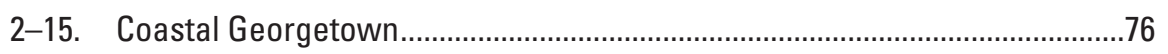

2-16. Black River at Kingstree .........................................................................

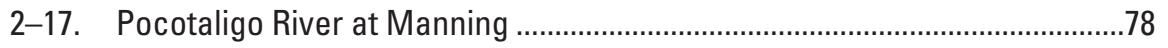

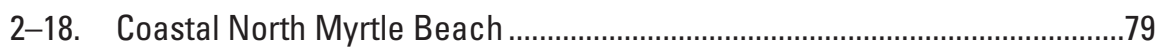

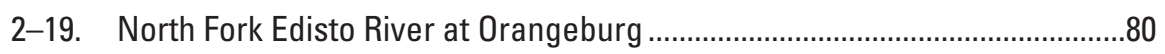

2-20. Green Swamp near Sumter............................................................................

\section{Tables}

1. Counties in South Carolina with one or more National Weather Service or U.S. Geological Survey rainfall gages recording more than 5 inches of rainfall for October 1-5, 2015

2. Communities, waterbodies, reach lengths, and number of high-water marks used to generate flood-inundation maps.

3. Selected recurrence intervals and the associated annual exceedance probability........7

4. Flood-peak gage heights, peak streamflows, and estimated annual exceedance probabilities for the October 2015 flood at selected U.S. Geological Survey streamgages in South Carolina

5. Flood-frequency statistics for selected U.S. Geological Survey streamgages in South Carolina. 


\section{Conversion Factors}

Inch/Pound to International System of Units

\begin{tabular}{lcl}
\hline \multicolumn{1}{c}{ Multiply } & By & \multicolumn{1}{c}{ To obtain } \\
\hline inch (in.) & Length & millimeter $(\mathrm{mm})$ \\
foot (ft) & 25.4 & meter $(\mathrm{m})$ \\
mile (mi) & 0.3048 & kilometer $(\mathrm{km})$ \\
\hline & 1.609 & \\
\hline square foot $\left(\mathrm{ft}^{2}\right)$ & Area & square meter $\left(\mathrm{m}^{2}\right)$ \\
square mile $\left(\mathrm{mi}^{2}\right)$ & 0.09290 & square kilometer $\left(\mathrm{km}^{2}\right)$ \\
\hline & 2.590 & \\
\hline cubic foot per second $\left(\mathrm{ft}^{3} / \mathrm{s}\right)$ & Flow rate & \\
\hline & 0.02832 & cubic meter per second $\left(\mathrm{m}^{3} / \mathrm{s}\right)$ \\
\hline foot per mile $(\mathrm{ft} / \mathrm{mi})$ & Hydraulic gradient & \\
\hline
\end{tabular}

\section{Datum}

Vertical coordinate information is referenced to the North American Vertical Datum of 1988 (NAVD 88).

Horizontal coordinate information is referenced to the North American Datum of 1983 (NAD 83).

Elevation, as used in this report, refers to distance above the vertical datum.

\section{Supplemental Information}

Stage, as used in this report, is the height of the water surface above an arbitrary datum established at the gage (gage datum).

\section{Abbreviations}
AEP annual exceedance probability
DEM digital elevation model
FEMA Federal Emergency Management Agency
GIS geographic information system
GPS global positioning system
HWM high-water mark
lidar light detection and ranging
NWS National Weather Service
USGS U.S. Geological Survey 



\title{
Flood-Inundation Maps of Selected Areas Affected by the Flood of October 2015 in Central and Coastal South Carolina
}

\author{
By Jonathan W. Musser, Kara M. Watson, Jaime A. Painter, and Anthony J. Gotvald
}

\begin{abstract}
Heavy rainfall occurred across South Carolina during October 1-5, 2015, as a result of an upper atmospheric low-pressure system that funneled tropical moisture from Hurricane Joaquin into the State. The storm caused major flooding in the central and coastal parts of South Carolina. Almost 27 inches of rain fell near Mount Pleasant in Charleston County during this period. U.S. Geological Survey (USGS) streamgages recorded peaks of record at 17 locations, and 15 other locations had peaks that ranked in the top 5 for the period of record. During the October 2015 flood event, USGS personnel made about 140 streamflow measurements at 86 locations to verify, update, or extend existing rating curves (which are used to compute streamflow from monitored river stage). Immediately after the storm event, USGS personnel documented 602 high-water marks, noting the location and height of the water above land surface. Later in October, 50 additional high-water marks were documented near bridges for South Carolina Department of Transportation. Using a subset of these high-water marks, 20 flood-inundation maps of 12 communities were created. Digital datasets of the inundation area, modeling boundary, and water depth rasters are all available for download.
\end{abstract}

\section{Introduction}

The presence of an upper atmospheric low-pressure system over the Southeast funneled tropical moisture from Hurricane Joaquin into South Carolina during the period October 1-5, 2015, causing historic rainfall amounts (http://www.weather.com/news/news/stunning-meteorologicalimages-october-2015-flooding, accessed October 8, 2015)

(fig. 1). Widespread heavy rainfall resulted in major flooding in areas from the central part of the State to the coast. Some areas received more than 20 inches of rainfall over the period October 1-5, 2015 (fig. 2; National Weather Service, written commun., October 7, 2015). U.S. Geological Survey (USGS) personnel made about 140 streamflow measurements at 86 locations to verify, update, or extend existing rating curves (which are used to compute streamflow from monitored river stage). One USGS raingage at Black River at Kingstree, SC (02136000) recorded 22.89 inches of rain for the period October 1-5, 2015 (fig. 2). Flooding from this event resulted in at least 17 fatalities (http://www.reuters.com/article/2015/10/07/us-usa-weatherfloods-idUSKCN0S11E720151007, accessed October 8, 2015). In the rural counties, conservative estimates of agricultural losses are expected to be at least $\$ 300$ million, and total damages across the State will likely exceed $\$ 1$ billion (http://www.latimes.com/nation/la-na-south-carolina-postcards20151008-htmlstory.html, accessed October 9, 2015).

\section{Purpose and Scope}

The purpose of this report is to document the data collection, flood peak magnitudes, and flood-inundation products generated by the USGS in support of the Federal Emergency Management Agency (FEMA) response and recovery operations following the October 1-5, 2015, flood event throughout central and coastal South Carolina. High-water mark identification and surveying methods as well as flood-inundation maps depicting estimates of the areal extent and depth of flooding are presented and described. 


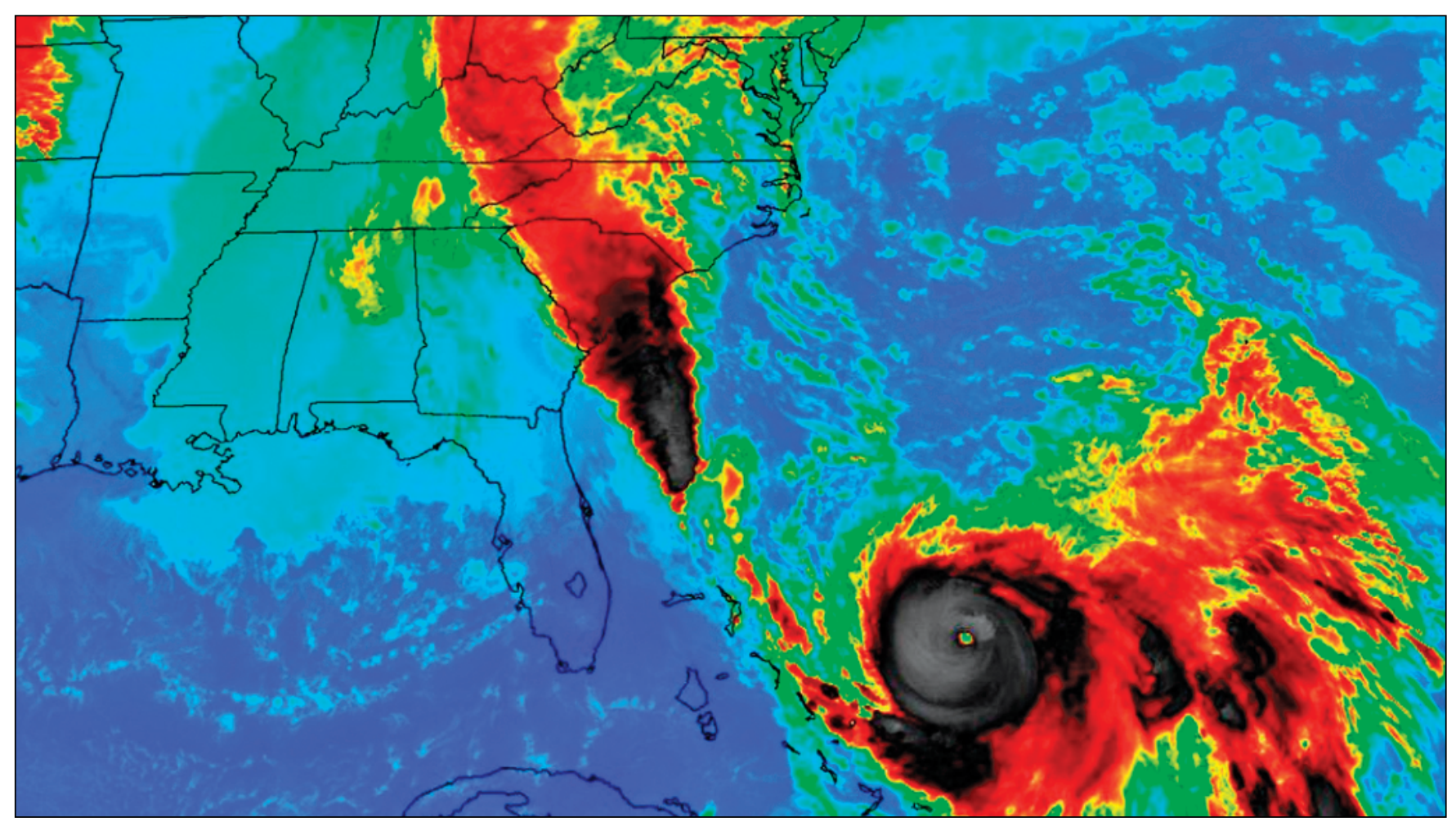

Figure 1. Infrared satellite image of the intense rainfall in South Carolina during the morning of October 3, 2015 (from Feaster and others, 2015; National Aeronautics and Space Administration). Black areas show the highest rainfall amounts.

\section{Description of the Study Area}

South Carolina is located in the southeastern United States, adjacent to the Atlantic Ocean, and has an area of 31,055 square miles. Most of the State is within two physiographic regions: Piedmont and Coastal Plain (Cooke, 1936; fig. 3). The Piedmont is characterized by rolling hills, elongated ridges, and moderately deep to shallow valleys. Piedmont land-surface elevations range from about 1,000 feet (ft) above sea level at the Blue Ridge foothills to about $400 \mathrm{ft}$ above sea level at the Fall Line, which is the name given to the boundary between the Piedmont and Coastal Plain regions (fig. 3; Feaster and others, 2015).
About two-thirds of the State is in the Coastal Plain region (Badr and others, 2004). In the Coastal Plain, bedrock is overlain by sediments, which thicken from just a few feet near the Fall Line to about 3,800 ft at the southernmost corner of the State. At the Fall Line, a narrow, hilly region, known as the Sand Hills (fig. 3), is located where the Piedmont descends to the Coastal Plain (National Oceanic and Atmospheric Administration, 2015). The Sand Hills region is about 30 to 40 miles wide with elevations ranging from about 500 to $200 \mathrm{ft}$. The lower part of the Coastal Plain consists of low-elevation, flat plains with many swamps, marshes, dunes, barrier islands, and beaches, which typically are lower, flatter, and more poorly drained than the upper part of the Coastal Plain (Omernik, 1987; Feaster and others, 2015). 


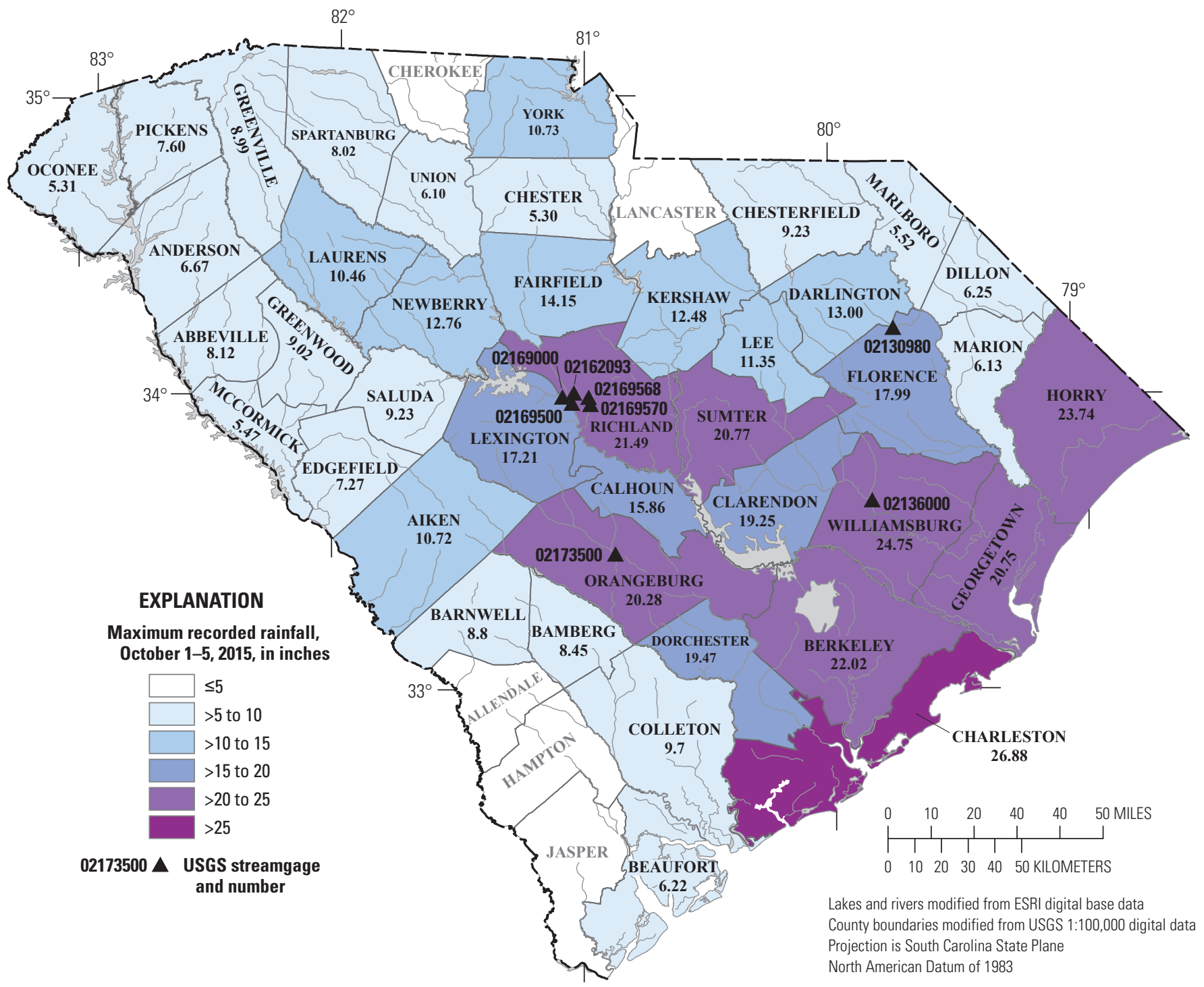

Figure 2. Counties in South Carolina with one or more National Weather Service or U.S. Geological Survey rainfall gages recording more than 5 inches of rainfall for 0 ctober 1-5, 2015, and U.S. Geological Survey streamgages with associated flood-inundation maps. 

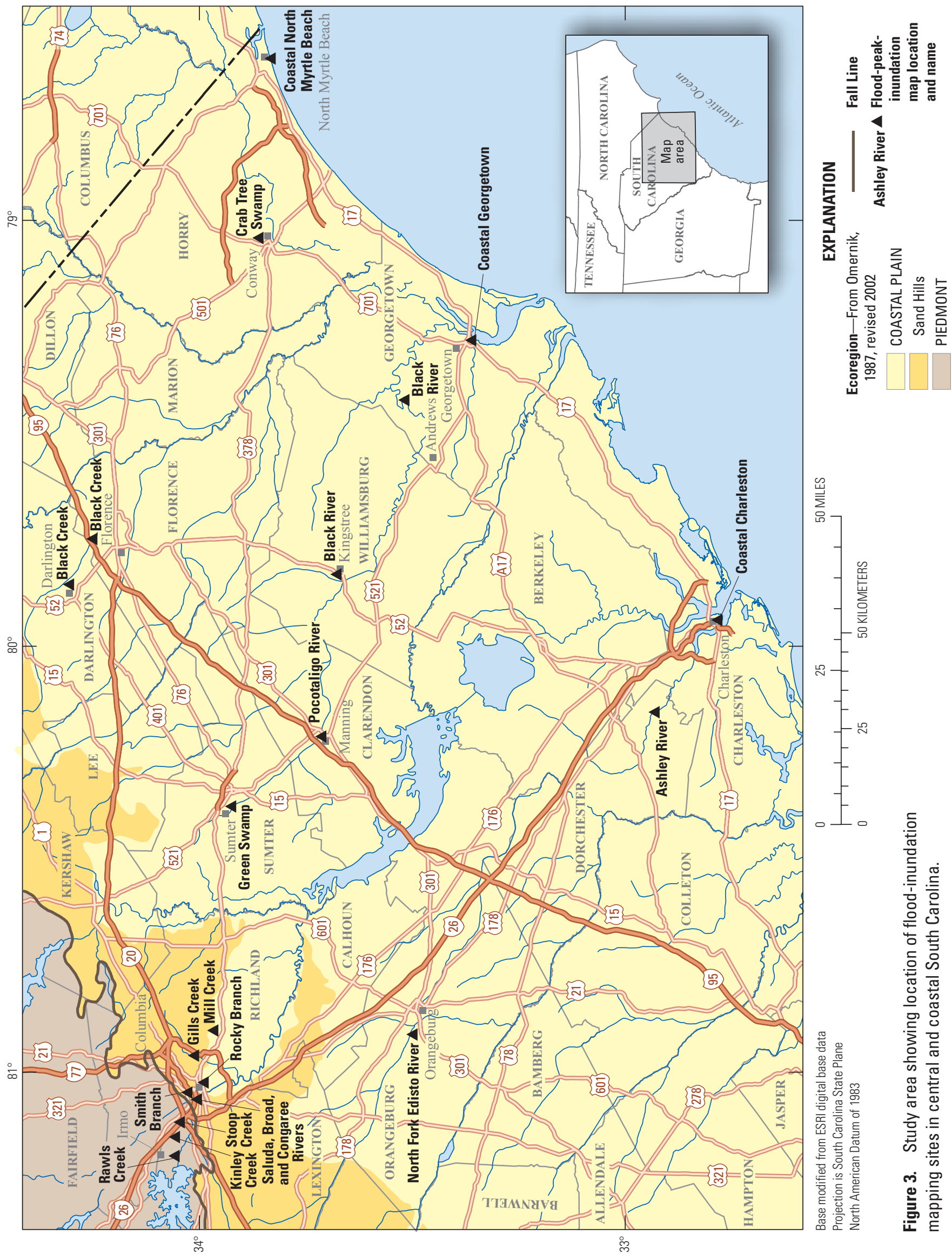


\section{Conditions Leading to the Flood of October 2015}

Heavy rainfall occurred across South Carolina during October 1-5, 2015, as a result of an upper atmospheric low-pressure system that funneled tropical moisture from Hurricane Joaquin into the State. The storm caused major flooding in the central and coastal areas of South Carolina (Feaster and others, 2015). The National Weather Service (NWS) and the USGS recorded record rainfall at multiple locations. Table 1 and figure 2 show the largest recorded rainfall for counties where a rainfall value was greater than 5 inches (http://www.weather.gov/media/chs/products/PNS/ PNS_20151005_1602.pdf and http://www.weather.gov/cae/ HistoricFloodingOct2015.html, accessed January 12, 2016; National Weather Service, written commun., January 21, 2016, and February 10, 2016).

\section{Methods Used}

The methods by which high-water marks (HWM) caused by heavy rainfall from Hurricane Joaquin in South Carolina were identified, documented, and referenced are discussed in this section. The methods by which these HWMs were used to create flood-inundation maps are also discussed as well as the methods by which the estimation of flood magnitude and frequency were developed through analysis of the annual peak streamflows at nine USGS streamgages that are within the areas of the flood-inundation maps.

\section{Collection of High-Water Mark Data}

High-water marks are the evidence of the highest water levels during a flood. The best HWMs are formed from small seeds or floating debris carried by flood waters that adhere to smooth surfaces or lodge in tree bark to form a distinct line. Stain lines on buildings, fences, and other structures also provide excellent marks. HWMs are best identified immediately following the peak stage because time and weather (wind, rain, sun) may blow, wash, or fade away the evidence of the peak water line. Care was taken to identify HWMs as far from the main channel as feasible where velocities generally are small and where wave action and pileup or drawdown effects of fast-moving waters are best avoided.

USGS field crews identified 602 HWMs in South Carolina with a depth above land surface measurement in feet and surveyed for elevation above land surface. Identification of HWMs began on October 7 and continued through October 16, 2015. After an acceptable HWM was found, a more permanent identification mark was established, such as a Parker-Kalon (PK) nail with a disk, a stake, a chiseled mark, or a paint line; if possible, the identification marks were accompanied by orange flagging. Written descriptions,
Table 1. Counties in South Carolina with one or more National Weather Service or U.S. Geological Survey rainfall gages recording more than 5 inches of rainfall for October 1-5, 2015.

[USGS, U.S. Geological Survey; CoCoRahs, Community Collaborative Rain, Hail and Snow Network; Coop, National Weather Service Cooperative Observer Program; E, east; N, north; S, south; W, west]

\begin{tabular}{|c|c|c|}
\hline County & $\begin{array}{l}\text { National Weather Service } \\
\text { or U.S. Geological Survey } \\
\text { reporting location }\end{array}$ & $\begin{array}{l}\text { Rainfall } \\
\text { amount }\end{array}$ \\
\hline Abbeville & Due West 2 S CoCoRahs & 8.12 \\
\hline Aiken & McTier Creek USGS-Monetta & 10.72 \\
\hline Anderson & Anderson 8 SE CoCoRahs & 6.67 \\
\hline Bamberg & Bamberg Coop & 8.45 \\
\hline Barnwell & Barnwell Coop & 8.80 \\
\hline Beaufort & 4 NNE Beaufort CoCoRahs & 6.22 \\
\hline Berkeley & 1 NNW Limerick Raws & 22.02 \\
\hline Calhoun & ENE St. Matthews CoCoRahs & 15.86 \\
\hline Charleston & 6 NE Mount Pleasant CoCoRahs & 26.88 \\
\hline Chester & Chester 1 SE Coop & 5.30 \\
\hline Chesterfield & Chesterfield Coop & 9.23 \\
\hline Clarendon & Manning 8.2 S CoCoRahs & 19.25 \\
\hline Colleton & 3 ENE Walterboro CoCoRahs & 9.70 \\
\hline Darlington & Darlington 7 SSW CoCoRahs & 13.00 \\
\hline Dillon & Dillon 4 NW CoCoRahs & 6.25 \\
\hline Dorchester & 3 NW Summerville & 19.47 \\
\hline Edgefield & Edgefield $11 \mathrm{~N}$ CoCoRahs & 7.27 \\
\hline Fairfield & Longtown Coop & 14.15 \\
\hline Florence & Coward 5 NNW CoCoRahs & 17.99 \\
\hline Georgetown & Georgetown 4 SSW Coop & 20.75 \\
\hline Greenville & KSCSIMPS9 Supplementary & 8.99 \\
\hline Greenwood & Greenwood 3.4 NNW CoCoRahs & 9.02 \\
\hline Horry & Longs Coop & 23.74 \\
\hline Kershaw & Lugoff Coop & 12.48 \\
\hline Laurens & Clinton 1.7 SSW CoCoRahs & 10.46 \\
\hline Lee & Bishopville Coop & 11.35 \\
\hline Lexington & Chapin 1.4 S CoCoRahs & 17.21 \\
\hline Marion & Mullins 1 SSE Coop & 6.13 \\
\hline Marlboro & Bennetsville 1 SE CoCoRahs & 5.52 \\
\hline McCormick & Little R. USGS Mt Carmel & 5.47 \\
\hline Newberry & Little Mountain Coop & 12.76 \\
\hline Oconee & Seneca 2.6 WSW CoCoRahs & 5.31 \\
\hline Orangeburg & Holly Hill 0.4 N CoCoRahs & 20.28 \\
\hline Pickens & Clemson 0.8 NE CoCoRahs & 7.60 \\
\hline Richland & Gills Creek Rcwinds - Columbia & 21.49 \\
\hline Saluda & Saluda USGS & 9.23 \\
\hline Spartanburg & KSCENORE4 Supplementary & 8.02 \\
\hline Sumter & Sumter 0.3 NNE CoCoRahs & 20.77 \\
\hline Union & Whitmire Raws 5 NE Coop & 6.10 \\
\hline Williamsburg & Kingstree weather spotter & 24.75 \\
\hline York & KSCYORK5 Supplementary & 10.73 \\
\hline
\end{tabular}


sketches, photographs, and global positioning system (GPS) horizontal measurements obtained with a hand-held GPS unit were made so the marks could easily be found later and surveyed to the standard vertical datum, North American Vertical Datum of 1988 (NAVD 88). The HWMs were grouped by location, and 20 of these locations were identified as inundation mapping sites where there were at least three HWMs and flooding was apparent in a nearby city or town. Fifty additional HWMs were documented in late October as part of a project funded by the South Carolina Department of Transportation. During the mapping process, the HWMs were identified and checked for location and elevation accuracy through comparison of field note diagrams and descriptions to aerial photography and detailed street and parcel maps. If the location could not be determined accurately or the elevation was substantially different than other HWMs in the area, the HWM was not used. A total of 494 HWMs from the initial 602 marks were used, as well as $16 \mathrm{HWMs}$ from the late October survey. The complete list of the 510 HWMs used in the analysis is provided in appendix 1. (One HWM is listed twice because it was used in two different flood-inundation maps.) The HWM data listed in appendix 1 are taken from field notes made by different people on different days. In some cases during the recording of waterbody names, a HWM on a small tributary of a stream was recorded as being on the stream itself. Although an attempt was made for consistent recording of information, some data may be incomplete.

\section{Flood-Inundation Mapping}

Flood-inundation maps for a total of 20 locations in 12 communities from central to coastal South Carolina were generated using a geographic information system (GIS). These maps depict estimates of the areal extent and depth of flooding that correspond to the HWMs identified and surveyed by the USGS following the flood event. Table 2 lists the community, waterbody, reach length, and number of HWMs used to generate the flood-inundation maps. The first step in the generation of the flood-inundation maps was the creation of a flood-elevation raster surface. Flood extent and depth surfaces were created independently for each community, using the HWM elevations and one of three interpolation/geoprocessing techniques that was deemed most appropriate to use for the type of flooding that existed within the community. A geographic limit was placed on the extent of the generated surface based on the distribution of HWMs and an understanding of the natural hydrologic flow in the area of each community.

Table 2. Communities, waterbodies, reach lengths, and number of high-water marks used to generate flood-inundation maps.

\begin{tabular}{|c|c|c|c|}
\hline Community & Waterbody & $\begin{array}{l}\text { Reach length } \\
\text { (miles) }\end{array}$ & $\begin{array}{c}\text { Number of high- } \\
\text { water marks }\end{array}$ \\
\hline Andrews & Black River & 50.6 & 19 \\
\hline Charleston & Ashley River and tributaries & 34.1 & 35 \\
\hline Charleston & Atlantic Ocean & 2.3 & 12 \\
\hline Columbia & Gills Creek and tributaries & 19.9 & 215 \\
\hline Columbia & Kinley Creek & 4.0 & 15 \\
\hline Columbia & Mill Creek and tributaries & 0.3 & 14 \\
\hline Columbia & Rawls Creek & 2.4 & 26 \\
\hline Columbia & Rocky Branch & 2.0 & 23 \\
\hline Columbia & Saluda, Broad, and Congaree Rivers & 18.0 & 22 \\
\hline Columbia & Smith Branch & 2.6 & 17 \\
\hline Columbia & Stoop Creek & 2.9 & 15 \\
\hline Conway & Crab Tree Swamp & 1.5 & 10 \\
\hline Darlington & Black Creek and tributaries & 5.1 & 3 \\
\hline Florence & Black Creek and tributaries & 4.5 & 5 \\
\hline Georgetown & Sampit, Great Pee Dee, and Waccamaw Rivers & 1.8 & 8 \\
\hline Kingstree & Black River and tributaries & 4.9 & 18 \\
\hline Manning & Pocotaligo River & 6.3 & 7 \\
\hline North Myrtle Beach & Atlantic Ocean & 2.4 & 13 \\
\hline Orangeburg & North Fork Edisto River & 4.7 & 6 \\
\hline Sumter & Green Swamp and tributaries & 5.9 & 28 \\
\hline
\end{tabular}


One flood-elevation interpolation method used the HWM elevations as points and interpolated between these elevations to generate the elevation surface using the ArcGIS "Topo to Raster" tool with the point interpolation procedure (http://pro.arcgis.com/en/pro-app/tool-reference/3d-analyst/ how-topo-to-raster-works.htm, accessed November 2015). This approach was used when the flooded area was adjacent to a large, low gradient, body of water such as a swamp or when the flooded area was a coastal community on the Atlantic Ocean.

A second method used the "Topo to Raster" tool with the cross sections interpolation procedure (http://pro.arcgis. com/en/pro-app/tool-reference/3d-analyst/how-topo-to-rasterworks.htm, accessed November 2015). A cross section was drawn through the location of the HWM and was run perpendicular to the direction of the flood flow. If there were multiple HWMs in an area with the same or similar elevations, one cross section was drawn that either passed through the HWMs or through the center of a group of HWMs. The elevation of the HWM was assigned to the water-surface elevation of the cross section. This method was used when flooding was a result of overtopped banks of rivers or streams.

A third method used a regional flood-elevation approach by grouping HWMs with similar water-surface elevations into a single flood-elevation region. A constant value elevation surface based on one point or an average of multiple points was used as the water surface for an area. This method was used when (1) an interpolation between HWMs was not possible because of the paucity of HWMs, (2) there was very little variation in elevations among the HWMs, and (3) flooding in the community was a result of a variety of unrelated reasons, such as localized flooding from tributaries or poor drainage rather than from the main (mapped) channel.

The flood-elevation surface that was created by using one of the three described methods was then combined with a 10 -ft cell size digital elevation model (DEM). The DEM was derived from light detection and ranging (lidar) data having an 18.4-centimeter vertical root-mean-square error and a 1.4-meter nominal point spacing (http://www.dnr.sc.gov/ GIS/lidar.html). An inundated area was depicted where the flood-elevation surface was higher than the DEM land surface. The depth of flooding was determined as the difference between the flood-elevation surface and the DEM land surface. Because of the large number of bridges involved in the flood-inundation mapping, the inundation surfaces were not clipped to show any bridges that were not inundated.

Some uncertainties exist with the flood-inundation mapping due to the methods of mapping as well as the numbers of HWMs. The flood-elevation surfaces were all created using interpolation between HWM elevations without any direct hydraulic modeling. As a result, changes in the physical nature of the flood plain, such as change in slope or width, are not accounted for. Additionally, the distance between HWMs has an effect on how accurate the interpolation is between them. The greater the distance between HWMs, the greater the possibility for a less accurate flood-elevation surface. Finally, some extrapolation was done beyond the most upstream and downstream HWMs. In many cases, the boundary was extended to a road or a bridge crossing.

\section{Flood Probabilities of Peak Streamflows}

Information commonly needed immediately after a major flood includes the frequency of peak discharges at the magnitudes observed during the event. Flood-frequency analyses for streamgages with sufficient record can provide insight into the occurrence or re-occurrence of peak discharges of varying magnitudes. The annual exceedance probability (AEP) for a particular streamflow is the probability of that streamflow being equaled or exceeded in any given year. For example, an $\mathrm{AEP}$ of 0.01 means there is a 1 percent $(\mathrm{AEP} \times 100)$ chance of that flow magnitude being equaled or exceeded in any given year. Stated another way, the odds are 1 in 100 that the indicated flow will be equaled or exceeded in any given year. The traditional concept of recurrence interval is directly related to the AEP. By definition, the recurrence interval (in years) corresponding to a particular AEP is equal to one divided by the flood probability. For example, the AEP of 0.01 (or 1 percent) corresponds to the 100 -year flood. Table 3 lists the correspondence between AEP in percent and recurrence intervals for commonly used flood probabilities.

Updated at-site flood-frequency discharges for selected AEPs (50-, 20-, 10-, 4-, 2-, 1-, 0.5-, and 0.2-percent) were computed for USGS streamgages in the areas where floodinundation maps were created using the computer program PEAKFQ, version 7.2 (Flynn and others, 2006; Veilleux and others, 2014). The PEAKFQ program is based on guidelines provided by the Interagency Advisory Committee on Water Data (1982) in Bulletin 17B. The October 2015 peak streamflows were included in the PEAKFQ analyses per guidance from USGS Office of Surface Water Technical Memorandum 2013.01 (Mason, 2013).

Table 3. Selected recurrence intervals and the associated annual exceedance probability.

\begin{tabular}{cc}
$\begin{array}{c}\text { Recurrence interval } \\
\text { (years) }\end{array}$ & $\begin{array}{c}\text { Annual } \\
\text { exceedance probability } \\
\text { (percent) }\end{array}$ \\
\hline 2 & 50 \\
5 & 20 \\
10 & 10 \\
25 & 4 \\
50 & 2 \\
100 & 1 \\
200 & 0.5 \\
500 & 0.2 \\
\hline
\end{tabular}


The updated at-site flood-frequency discharges computed using PEAKFQ were weighted with the regression equation estimates from Feaster and others (2009) for rural streamgages or with the regression equations estimates from Feaster and others (2014) for urban streamgages. The weighting method used is outlined in Bulletin 17B (Interagency Advisory Committee on Water Data, 1982, appendix 8). The weighted discharge estimates were then used to determine the AEP associated with the October 2015 peak streamflow. Updated flood-frequency estimates were not computed for the regulated streamgage, Congaree River at Columbia, SC (02169500), because of the complexities of the regulation and detailed statistical analysis that would be needed to update the floodfrequency estimates. Given that the October 2015 discharge peak was not the peak of record, the most recent published values in Federal Emergency Management Agency (2001) were used to estimate the AEP associated with the peak streamflow for that streamgage.

\section{Estimated Magnitudes and Flood Probabilities of Peak Streamflows}

Peak gage-height data, peak streamflow data, and the corresponding AEPs (in percent) determined from the October 2015 flood for the nine USGS streamgages that record annual peak streamflow in the areas where floodinundation maps were created are presented in table 4 . The

Table 4. Flood-peak gage heights, peak streamflows, and estimated annual exceedance probabilities for the 0 ctober 2015 flood at selected U.S. Geological Survey streamgages in South Carolina.

[Data shown are considered provisional as of the date of publication. Peak of record shown in bold. Abbreviations: USGS, U.S. Geological Survey; mi², square miles; $\mathrm{ft}^{3} / \mathrm{s}$, cubic feet per second, $\mathrm{ft}$, feet; AEP, annual exceedance probability. <, less than; - , not applicable or not available]

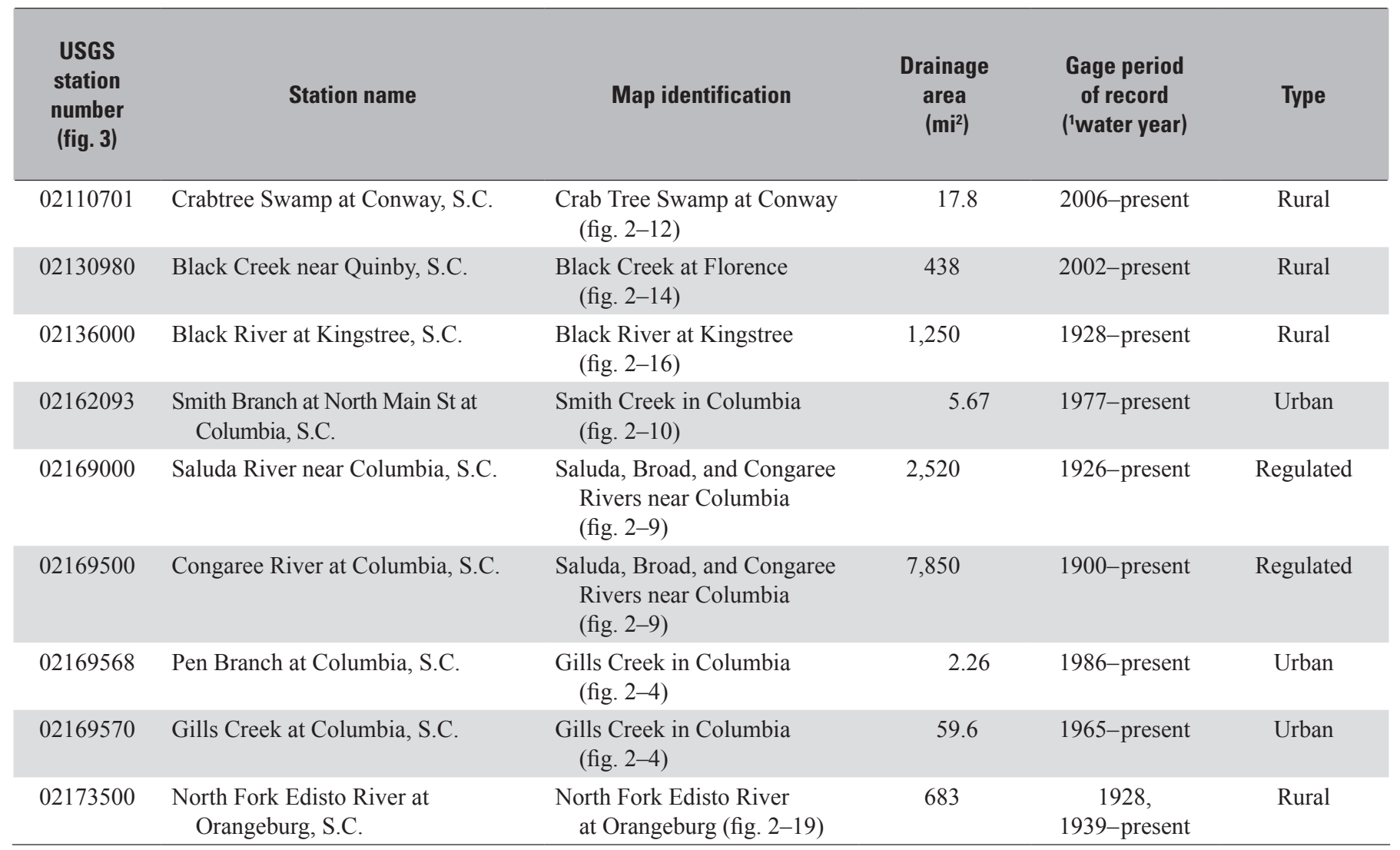

${ }^{1}$ Water year refers to the period from October 1 to September 30 and is identified by the year in which the period ends. For example, October 1, 2001, to September 30, 2002, is water year 2002.

${ }^{2}$ Determined using AEP estimates that were computed using PEAKFQ and weighted with regional regression equation estimates from Feaster and others (2009).

${ }^{3}$ Peak streamflow currently (January 2016) not available.

${ }^{4}$ Determined using AEP estimates from Federal Emergency Management Agency (2001). 
flood-inundation map identification name associated with each streamgage is listed in table 4 . The streamgage locations are shown in figure 3 as well as in the flood-inundation maps in appendix 2. The data listed in table 4 currently (January 2016) are considered provisional until final approval of the data. New gage-height records were set at six of the nine USGS streamgages listed in table 4 . The peak discharge currently (January 2016) is not available for four of the six streamgages with peak gage height of record, so the AEPs were not estimated for these four streamgages (noted in table 4). Further analyses using indirect discharge measurement methods are being performed to estimate the peak discharge for these four streamgages. The flood-frequency statistics computed for this study are presented in table 5. The weighted floodfrequency statistics in table 5 were used to determine the AEP (in percent) associated with the October 2015 flood peak in table 4.

Table 4. Flood-peak gage heights, peak streamflows, and estimated annual exceedance probabilities for the 0ctober 2015 flood at selected U.S. Geological Survey streamgages in South Carolina.-Continued

[Data shown are considered provisional as of the date of publication. Peak of record shown in bold. Abbreviations: USGS, U.S. Geological Survey; $\mathrm{mi}^{2}$, square miles; $\mathrm{ft}^{3} / \mathrm{s}$, cubic feet per second, $\mathrm{ft}$, feet; AEP, annual exceedance probability. <, less than; —, not applicable or not available]

\begin{tabular}{|c|c|c|c|c|c|c|c|}
\hline \multicolumn{3}{|c|}{ Maximum prior to October 2015 flood } & \multicolumn{4}{|c|}{ Maximum for October 2015 flood } & \multirow[b]{2}{*}{$\begin{array}{c}\text { USGS } \\
\text { station } \\
\text { number } \\
\text { (fig. 3) }\end{array}$} \\
\hline Date & $\begin{array}{c}\text { Gage height } \\
\text { (ft) }\end{array}$ & $\begin{array}{c}\text { Streamflow } \\
\left(\mathrm{ft}^{3} / \mathrm{s}\right)\end{array}$ & Date & $\begin{array}{c}\text { Gage height } \\
\text { (ft) }\end{array}$ & $\begin{array}{c}\text { Streamflow } \\
\left(\mathrm{ft}^{3} / \mathrm{s}\right)\end{array}$ & $\begin{array}{l}\text { Estimated annual } \\
\text { exceedance } \\
\text { probability } \\
\text { (percent) }\end{array}$ & \\
\hline $5 / 14 / 12$ & 13.03 & 1,510 & $10 / 4 / 15$ & 20.20 & 3,120 & ${ }^{2} 1$ to 0.5 & 02110701 \\
\hline 9/9/2004 & 16.80 & 6,450 & $10 / 4 / 2015$ & 16.81 & 6,530 & ${ }^{2} 4$ to 2 & 02130980 \\
\hline $6 / 14 / 1973$ & 19.77 & 58,000 & $10 / 6 / 2015$ & 22.65 & 83,700 & ${ }^{2}<0.2$ & 02136000 \\
\hline $7 / 21 / 2013$ & 15.12 & 3,820 & $10 / 4 / 2015$ & 18.87 & (3) & - & 02162093 \\
\hline $10 / 2 / 1929$ & 15.22 & 67,000 & $10 / 4 / 2015$ & 14.26 & (3) & - & 02169000 \\
\hline $8 / 27 / 1908$ & 39.80 & 364,000 & $10 / 4 / 2015$ & 31.81 & 185,000 & ${ }^{4} 10$ to 4 & 02169500 \\
\hline $7 / 24 / 1997$ & 9.10 & 2,350 & $10 / 4 / 2015$ & 11.33 & (3) & - & 02169568 \\
\hline $2 / 24 / 1979$ & 8.66 & 2,880 & $10 / 4 / 2015$ & 19.60 & (3) & - & 02169570 \\
\hline Sept. 1928 & 14.70 & 10,000 & $10 / 4 / 2015$ & 13.64 & 8,640 & ${ }^{2} 2$ to 1 & 02173500 \\
\hline
\end{tabular}


Table 5. Flood-frequency statistics for selected U.S. Geological Survey streamgages in South Carolina.

[USGS, U.S. Geological Survey. AEP, annual exceedance probability: G, estimated from the Bulletin 17B (Interagency Advisory Committee on Water Data, 1982) analysis of the streamgaging station; $\mathrm{R}$, estimated from the regression equation; and $\mathrm{W}$, weighted estimate]

\begin{tabular}{|c|c|c|c|c|c|c|c|c|c|c|c|}
\hline \multirow{2}{*}{$\begin{array}{l}\text { USGS } \\
\text { station } \\
\text { number }\end{array}$} & \multirow{2}{*}{$\begin{array}{c}\text { Number } \\
\text { of annual } \\
\text { peaks }\end{array}$} & \multirow{2}{*}{$\begin{array}{l}\text { Historic } \\
\text { period } \\
\text { of record } \\
\text { (years) }\end{array}$} & \multicolumn{9}{|c|}{ Streamflow, in cubic feet per second } \\
\hline & & & G & $\mathbf{R}$ & $\mathbf{W}$ & G & $\mathbf{R}$ & $\mathbf{w}$ & G & $\mathbf{R}$ & $\mathbf{w}$ \\
\hline $02110701^{1}$ & 11 & 0 & 970 & 390 & 799 & 1,590 & 748 & 1,290 & 2,060 & 1,030 & 1,650 \\
\hline $02130980^{1}$ & 15 & 0 & 1,440 & 2,830 & 1,690 & 2,670 & 4,780 & 3,210 & 3,740 & 6,240 & 4,530 \\
\hline $02173500^{1,2}$ & 79 & 124 & 2,260 & 3,900 & 2,300 & 3,630 & 6,550 & 3,730 & 4,710 & 8,550 & 4,880 \\
\hline
\end{tabular}

\begin{tabular}{|c|c|c|c|c|c|c|c|c|c|c|c|}
\hline \multirow{2}{*}{$\begin{array}{l}\text { USGS } \\
\text { station } \\
\text { number }\end{array}$} & \multirow{2}{*}{$\begin{array}{c}\text { Number } \\
\text { of annual } \\
\text { peaks }\end{array}$} & \multirow{2}{*}{$\begin{array}{l}\text { Historic } \\
\text { period } \\
\text { of record } \\
\text { (years) }\end{array}$} & \multicolumn{9}{|c|}{ Streamflow, in cubic feet per second } \\
\hline & & & G & $\mathbf{R}$ & $\mathbf{w}$ & G & $\mathbf{R}$ & $\mathbf{w}$ & G & $\mathbf{R}$ & $\mathbf{w}$ \\
\hline $02110701^{1}$ & 11 & 0 & 2,720 & 1,410 & 2,130 & 3,270 & 1,740 & 2,520 & 3,860 & 2,100 & 2,950 \\
\hline $02130980^{1}$ & 15 & 0 & 5,400 & 8,140 & 6,480 & 6,880 & 9,680 & 8,060 & 8,590 & 11,200 & 9,700 \\
\hline $02173500^{1,2}$ & 79 & 124 & 6,260 & 11,100 & 6,560 & 7,560 & 13,200 & 8,000 & 8,980 & 15,300 & 9,590 \\
\hline
\end{tabular}

\begin{tabular}{|c|c|c|c|c|c|c|c|c|}
\hline \multirow{3}{*}{$\begin{array}{l}\text { USGS } \\
\text { station } \\
\text { number }\end{array}$} & \multirow{3}{*}{$\begin{array}{c}\text { Number } \\
\text { of annual } \\
\text { peaks }\end{array}$} & \multirow{3}{*}{$\begin{array}{l}\text { Historic } \\
\text { period } \\
\text { of record } \\
\text { (years) }\end{array}$} & \multicolumn{6}{|c|}{ Streamflow, in cubic feet per second } \\
\hline & & & \multicolumn{3}{|c|}{ 0.2-percent chance AEP } & \multicolumn{3}{|c|}{ 0.5-percent chance AEP } \\
\hline & & & $\mathbf{G}$ & $\mathbf{R}$ & $\mathbf{w}$ & $\mathbf{G}$ & $\mathbf{R}$ & $\mathbf{w}$ \\
\hline $02110701^{1}$ & 11 & 0 & 4,500 & 2,430 & 3,370 & 5,430 & 2,940 & 4,010 \\
\hline $02130980^{1}$ & 15 & 0 & 10,600 & 12,800 & 11,600 & 13,600 & 14,900 & 14,300 \\
\hline $02136000^{1,2}$ & 89 & 124 & 57,900 & 29,100 & 47,200 & 79,700 & 34,300 & 59,700 \\
\hline $02173500^{1,2}$ & 79 & 124 & 10,600 & 17,500 & 11,300 & 12,800 & 20,400 & 13,900 \\
\hline
\end{tabular}

${ }^{1}$ Regression equation estimates from Feaster and others (2009).

${ }^{2}$ Historic adjustment. 


\section{Flood-Inundation Maps}

Twenty flood-inundation maps for 12 communities are provided in appendix 2 . The following sections describe each inundation mapping location. Descriptive tables of HWMs used in the inundation mapping are included in appendix 1. Digital flood-inundation data can be downloaded from http://water.usgs. gov/floods/events/2015/Joaquin/data_ofr20161019/.

\section{Black River Near Andrews}

The Black River flows east through the community of Andrews in Georgetown and Williamsburg Counties. A total of 19 HWMs were identified and surveyed within the community of Andrews. Eight HWMs were documented along a 30-mile stream reach of the Black River, four along a 6.5-mile reach of the Black Mingo Creek, five along Big Dam Swamp, one along Gin Branch, and one along Choppee Creek. Seventeen cross sections - 10 on the Black River, 4 on Black Mingo Creek, 2 on Big Dam Swamp, and 1 on Choppee Creek-were created and used to generate a flood-elevation surface. The flood elevations ranged from $6.8 \mathrm{ft}$ along the Black River to $23.4 \mathrm{ft}$ along Big Dam Swamp. The flood-inundation map for this location is shown in figure $2-1$.

\section{Ashley River Near Charleston}

The Ashley River is located in Dorchester and Charleston Counties and flows generally southeastward, emptying into the Atlantic Ocean. A total of 35 HWMs were documented18 on the Ashley River, 8 near Church Creek, 6 on Popperdam Creek, and 3 on Eagle Creek. Twenty-one cross sections15 on the Ashley River, 4 on Eagle Creek, and 2 on Popperdam Creek - were created and used to generate a flood-elevation surface. Two areas near Church Creek used a constant value surface. The HWMs ranged in elevation from $25.5 \mathrm{ft}$ near Big Bird Lane to $5.5 \mathrm{ft}$ near Great Oak Drive. An additional watersurface elevation was obtained from the USGS streamgage, Ashley River near North Charleston, SC (021720869), which peaked at $5.5 \mathrm{ft}$ on October 4, 2015. The flood-inundation map for this location is shown in figure 2-2.

\section{Coastal Charleston}

The city of Charleston is a coastal community located in Charleston County adjacent to the Atlantic Ocean. Twelve HWMs were identified in the community and used to generate a flood-elevation surface. The HWMs ranged in elevation from $4.0 \mathrm{ft}$ at Ashley Street to $9.3 \mathrm{ft}$ near King Street and Huger Street. The flood-inundation map for this location is shown in figure 2-3.

\section{Columbia}

The city of Columbia and its suburbs are located in Richland and Lexington Counties in the central part of South Carolina. The Saluda and Broad Rivers, which join to form the Congaree River, are the largest flowing waterbodies in the metropolitan area. HWMs were documented along seven tributaries as well as on these three rivers. The inundation mapping in the Columbia area was divided into a total of eight different maps - one for each of seven tributaries and one for the three large rivers.

\section{Gills Creek in Columbia}

Gills Creek and its tributaries are located in Richland County in the vicinity of the city of Columbia. Gills Creek flows generally southwestward and empties into the Congaree River. A total of 215 HWMs were documented, and 193 cross sections were created to map the inundated area. At the downstream end of the basin, the lowest HWM on Shop Road was $138.7 \mathrm{ft}$. At the upstream end of Gills Creek, the highest HWM was $191.5 \mathrm{ft}$ near Northshore Road. HWMs were surveyed on six different tributaries of Gills Creek. The highest HWM on each tributary is as follows: $193.5 \mathrm{ft}$ near Washington Road on Wildcat Creek; $213.6 \mathrm{ft}$ near Budon Court on Pen Branch; $257.5 \mathrm{ft}$ near Blue Bird Lane on Eightmile Branch; $219.0 \mathrm{ft}$ near Fireland Road on Little Jackson Creek; $241.8 \mathrm{ft}$ near Windsor Shores Drive on an unnamed tributary of Jackson Creek; and 231.7 near Parliament Lake Drive on Windsor Lake on Jackson Creek. The extent of the mapped inundation area (fig. 2-4) is bounded by the location of the lowest HWM at the downstream end of Gills Creek and approximately $1,500 \mathrm{ft}$ upstream from the location of the highest HWM. The extents of the mapped inundation area for the six tributaries are located the following distances upstream from the most upstream HWM: $960 \mathrm{ft}$ for a tributary of Wildcat Creek; $760 \mathrm{ft}$ for Pen Branch; $240 \mathrm{ft}$ for Little Jackson Creek; $60 \mathrm{ft}$ for an unnamed tributary of little Jackson Creek; and 1,800 ft for Jackson Creek. On October 4, 2015, at the USGS streamgage, Gills Creek at Columbia, SC (02169570), a peak stage of $19.6 \mathrm{ft}$ was recorded, and at Pen Branch at Columbia, SC (02169568), a peak stage of 11.33 was recorded. The floodinundation map for this location is shown in figure 2-4.

\section{Kinley Creek Near Columbia}

Kinley Creek is in Lexington County near the city of Irmo northwest of Columbia. The creek flows generally southeastward and empties into the Saluda River. A total of 15 HWMs were documented-13 on Kinley Creek and 2 on an unnamed tributary. The HWMs ranged in elevation from $227.8 \mathrm{ft}$ near Harbison Boulevard to $187.3 \mathrm{ft}$ on St. Andrews Road. On the unnamed tributary, the peak HWM was $235.6 \mathrm{ft}$ 
near Foxfire Drive. Fifteen cross sections - 11 on Kinley Creek and 4 on the unnamed tributary - were created and used to generate a flood-elevation surface. On the unnamed tributary, one cross section was created at each of the HWM locations at the upstream and downstream ends of the reach. Two other cross sections were spaced equidistant between the first two. The water-surface elevations that were assigned to the intermediate cross section were determined by using a ratio of the difference in elevation between the upstream and downstream HWMs and the distance between the cross sections. This prevented the cross sections on Kinley Creek from affecting the water-surface elevation on the tributary. The inundation area boundary is approximately $830 \mathrm{ft}$ upstream from the location of the highest HWM on Kinley Creek and approximately $230 \mathrm{ft}$ upstream from the location of the highest HWM on the unnamed tributary. The inundation area boundary is approximately $30 \mathrm{ft}$ downstream from the location of the lowest HWM. The flood-inundation map for this location is figure $2-5$.

\section{Mill Creek Near Columbia}

Mill Creek and its tributaries are located in Richland County near the city of Columbia. The creek flows generally southward and empties into the Congaree River. A total of 14 HWMs were documented in three separate areas. In the first area, $11 \mathrm{HWMs}$, ranging from $213.4 \mathrm{ft}$ upstream on a small lake to $203.5 \mathrm{ft}$ downstream, were documented on Mill Creek near Caughman Road. Seven cross sections were created to map the inundation area. The inundation boundary for this area is approximately $610 \mathrm{ft}$ upstream from the location of the highest HWM and approximately $150 \mathrm{ft}$ downstream from the location of the lowest HWM. In the second area, one HWM was measured on a small pond on an unnamed tributary of Mill Creek near Cardington Drive. A constant water surface at the value of this HWM, $239.1 \mathrm{ft}$, was used to model the inundated area of this pond and its adjacent area. In the third area, two HWMs were documented near Rawlinson Road on an unnamed tributary of Mill Creek. One HWM was on Ulmers Lake (238.0 ft) and one was on Griffin Lake (243.1 ft). Constant water-surface elevations, those of the HWMs, were used to model the inundated area for each of these lakes. The flood elevation in the intervening area between the lakes was interpolated from the two HWMs. The flood-inundation map for these locations is shown in figure 2-6.

\section{Rawls Creek Near Columbia}

Rawls Creek is in Lexington County near the city of Irmo northwest of Columbia. The creek flows generally southeastward and empties into the Saluda River. A total of 26 HWMs were documented-25 on Rawls Creek and 1 on Koon Branch. The HWMs ranged in elevation from $236.2 \mathrm{ft}$ on Coldstream Drive to $193.0 \mathrm{ft}$ at Saluda Shoals Park located on Bush River Road. Twenty-three cross sections were created to generate the flood-elevation surface. The inundation area boundary is approximately $125 \mathrm{ft}$ upstream from the location of the highest HWM and approximately $200 \mathrm{ft}$ downstream from the location of the lowest HWM. The flood-inundation map for this location is shown in figure 2-7.

\section{Rocky Branch in Columbia}

Rocky Branch flows through the city of Columbia in Richland County. Rocky Branch flows generally southwestward and empties into the Congaree River. A total of 23 HWMs were documented. The HWMs ranged in elevation from $223.5 \mathrm{ft}$ at a spot upstream from Pavillion Street to $148.7 \mathrm{ft}$ at South Parker Street. Twenty cross sections were created to generate the flood-elevation surface. The inundation area boundary is approximately $350 \mathrm{ft}$ upstream from the location of the highest HWM and approximately $310 \mathrm{ft}$ downstream from the location of the most downstream HWM near Olympia Avenue. The flood-inundation map for this location is shown in figure 2-8.

\section{Saluda, Broad, and Congaree Rivers Near Columbia}

The Saluda, Broad, and Congaree Rivers flow through Lexington and Richland Counties near and in the city of Columbia. In this area the Saluda River generally flows southeast and the Broad River flows south. The Saluda and Broad Rivers join to form the Congaree River, which flows southeast through the area. A total of $22 \mathrm{HWMs}$ were documented in the area -10 on the Saluda River and tributaries to the Saluda River, 6 on the Broad River, and 6 on the Congaree River. The highest HWM elevations were $193.6 \mathrm{ft}$ near Inlet Road on the Saluda River and $165.8 \mathrm{ft}$ upstream from Interstate 20 on the Broad River. The lowest HWM elevation was $134 \mathrm{ft}$ at Interstate 77 on the Congaree River. Twenty-one cross sections were created to generate the flood-elevation surface, with seven cross sections on the Saluda River, seven cross sections on the Broad River, and seven cross sections on the Congaree River. The upstream inundation area boundaries on the Saluda and Broad Rivers were approximately $290 \mathrm{ft}$ and approximately $730 \mathrm{ft}$, respectively, upstream from the locations of the highest HWMs. The downstream inundation area boundary was approximately $4,400 \mathrm{ft}$ downstream from the location of the lowest HWM on the Congaree River. About $6,000 \mathrm{ft}$ downstream from the U.S. Highways 21/176/321 bridge, the Congaree River flood plain widens substantially. There was extensive flooding along the Congaree River south of Interstate 77, but no HWMs were documented along this reach. The Columbia Canal runs adjacent to the Broad and Congaree Rivers and was breached during the flood event. The HWMs documented near the canal were all on the river side, 
so no mapping of the flood extent along the canal could be completed. The canal south of the U.S. Highway 176 bridge was not mapped. The flood-inundation map for this location is shown in figure 2-9. The following inundation areas intersect and overlap the inundation area delineated for the Saluda, Broad, and Congaree Rivers (fig. 2-9): Rawls Creek (fig. 2-7), Kinley Creek (fig. 2-5), Stoop Creek (fig. 2-11), Smith Branch (fig. 2-10), and Gills Creek (fig. 2-4).

\section{Smith Branch in Columbia}

Smith Branch is in Richland County and flows through the city of Columbia. Smith Branch flows generally westward and empties into the Broad River. A total of 17 HWMs were documented. The elevations of the HWMs ranged from $220.9 \mathrm{ft}$ upstream from Harden Street Extension to $165.6 \mathrm{ft}$ near Williamsburg Drive. Twelve cross sections were created to generate the flood-elevation surface. The inundation area boundary is approximately $190 \mathrm{ft}$ upstream from the location of the highest HWM and approximately $60 \mathrm{ft}$ downstream from the location of the lowest HWM. At the USGS streamgage, Smith Branch at North Main Street at Columbia, SC (02162093), a peak stage of $18.87 \mathrm{ft}$ was recorded on October 4, 2015 (Feaster and others, 2015). The flood-inundation map for this location is shown in figure 2-10.

\section{Stoop Creek Near Columbia}

Stoop Creek is in Lexington and Richland Counties between the cities of Irmo and Columbia. The creek flows generally southward and empties into the Saluda River. A total of $15 \mathrm{HWMs}$ were documented. The elevations of the HWMs ranged from $249.0 \mathrm{ft}$ on Bonnie Forest Boulevard to $183.5 \mathrm{ft}$ downstream from Bush River Road. Fifteen cross sections were created to generate the flood-elevation surface. The inundation area boundary is approximately $220 \mathrm{ft}$ upstream from the location of the highest HWM and approximately $410 \mathrm{ft}$ downstream from the location of the lowest HWM. The flood-inundation map for this location is shown in figure 2-11.

\section{Crab Tree Swamp at Conway}

The city of Conway is a coastal community centrally located in Horry County. The flooded area of the community flanked Crab Tree Swamp on the north and south and extended as far west as Main Street and east into Grier Swamp. The USGS streamgage, Crabtree Swamp at Conway, SC (02110701), recorded a peak stage of $20.2 \mathrm{ft}$ on October 5, 2015. Ten HWMs were documented and used to generate a flood-elevation surface. The HWMs ranged in elevation from $10.3 \mathrm{ft}$ at Busbee Street to $11.7 \mathrm{ft}$ on Main Street, U.S. Highway 701. The flood-inundation map for this location is shown in figure 2-12.

\section{Black Creek at Darlington}

Black Creek flows southeast through the city of Darlington in Darlington County. Three HWMs were identified and surveyed along a 2.5-mile reach of Black Creek and 5 miles of tributary including Swift Creek and Bellyache Creek. The elevations of the HWMs on Black Creek ranged from $92.1 \mathrm{ft}$ near Woods Dargan Road to $96.5 \mathrm{ft}$ near Darlington Country Club. The HWM located on Lawson Road near Bellyache Creek had an elevation of $116.0 \mathrm{ft}$. Three cross sections were created to generate the flood-elevation surface: one near the junction of Swift Creek and Black Creek, one on Black Creek, and one on Bellyache Creek. The flood-elevation surface of Black Creek was generated separately from the flood-elevation surface of Swift Creek and Bellyache Creek. The two floodelevation surfaces were then merged. Because of the lack of HWMs and the difference in HWM elevations for Swift Creek and Bellyache Creek, the area of inundation is uncertain for this part of the flood-inundation map. The flood-inundation map for this location is shown in figure 2-13.

\section{Black Creek at Florence}

Black Creek flows east through the community of Florence in Florence and Darlington Counties. Five HWMs were identified and surveyed along a 4.5-mile stream reach and ranged in elevation from $66.5 \mathrm{ft}$ at Crooked Creek Road to $80.9 \mathrm{ft}$ near Meadowbrook Drive. Five cross sections were created to generate the flood-elevation surface. The USGS streamgage, Black Creek near Quinby, SC (02130980), recorded a peak stage of $16.81 \mathrm{ft}$ and streamflow discharge of 6,530 cubic feet per second $\left(\mathrm{ft}^{3} / \mathrm{s}\right)$ on October 4, 2015 (Feaster and others, 2015). The flood-inundation map for this location is shown in figure $2-14$.

\section{Coastal Georgetown}

The city of Georgetown is located in Georgetown County on the west side of Winyah Bay, which is formed by the confluence of the Sampit River and the Great Pee Dee and Waccamaw Rivers. Eight HWMs, ranging in elevation from $4.5 \mathrm{ft}$ near Front and Meeting Streets to $14.7 \mathrm{ft}$ at Hawkins Street, were identified and used in the creation of a floodelevation surface. The flood-elevation surface was generated using a regional elevation approach. The flood-elevation surface for two small regions in the northwest part of town were created by using the average elevations of $14.6 \mathrm{ft}$ for one area and $8.6 \mathrm{ft}$ from a single HWM for the second area. A third region of $4.8 \mathrm{ft}$ included the area along Front Street near the Sampit River southeast to the bank of the Waccamaw-Great Pee Dee Rivers confluence. A regional flood elevation of $4.8 \mathrm{ft}$ based on three HWMs was used for this area. The floodinundation map for this location is shown in figure 2-15. 


\section{Black River at Kingstree}

The town of Kingstree is located in Williamsburg County at the confluence of the Black River and two tributaries. Kingstree Swamp Canal is on the west side of Kingstree, and an unnamed tributary of the Black River flows through the eastern part of the town. Flooding depth of as much as $4.7 \mathrm{ft}$ occurred on three sides of Kingstree. Localized flooding was identified in the center of town (1.2-1.6 ft depth) at Live Oak Avenue and Green Street. A total of 18 HWMs were documented - four on the Black River, four on Kingstree Swamp Canal, eight on an unnamed tributary, and two in the center of Kingstree. The HWM elevations ranged from $64.2 \mathrm{ft}$ at Live Oak Avenue to $46.6 \mathrm{ft}$ at two HWMs near E. Main Street. The highest HWM on Kingstree Swamp Canal, near Sandy Bay Road, had an elevation of $49.1 \mathrm{ft}$. Sixteen cross sections were created to generate the flood-elevation surface. The USGS streamgage, Black River at Kingstree (02136000), recorded a peak stage of $22.65 \mathrm{ft}$ on October 6, 2015. The flood-inundation map for this location is shown in figure 2-16.

\section{Pocotaligo River at Manning}

The Pocotaligo River flows east through the city of Manning in Clarendon County. A total of seven HWMs were documented - six on the Pocotaligo River and one on Ox Swamp. Four cross sections were created to generate the flood-inundation surface. The HWM elevations ranged from $86.8 \mathrm{ft}$ near Walker Street to $89.1 \mathrm{ft}$ near Interstate 95 . The flood-inundation map for this location is shown in figure 2-17.

\section{Coastal North Myrtle Beach}

North Myrtle Beach is a coastal community located in Horry County adjacent to the Atlantic Ocean. The inundated region of the community spanned approximately 2.4 miles along the coast from 62nd Avenue North to 20th Avenue North. Thirteen HWMs were documented, which ranged in elevation from $4.8 \mathrm{ft}$ at $62 \mathrm{nd}$ Avenue North to $6.4 \mathrm{ft}$ at 31 st Avenue North and 22nd Avenue North. These HWMs were used to create a flood-inundation surface. The floodinundation map for this location is shown in figure 2-18.

\section{North Fork Edisto River at Orangeburg}

The city of Orangeburg is located in central South Carolina on the North Fork Edisto River in Orangeburg County. Six HWMs were identified along a 4.7-mile stretch and ranged in elevation from $176.4 \mathrm{ft}$ at Shillings Bridge Road to $161.6 \mathrm{ft}$ at the U.S. 301 bridge. Six cross sections were created to generate the flood-elevation surface. The flood-inundation map for this location is shown in figure 2-19.

\section{Green Swamp Near Sumter}

The Green Swamp flows in a southeastern direction through the city of Sumter in Sumter County. A total of 28 HWMs were identified and surveyed within the city of Sumter. Ten HWMs were along a 4-mile stream reach of Green Swamp and Mush Swamp and eight HMWs were along Shot Pouch Branch. Seventeen cross sections were created from these HWMs to generate the flood-elevation surface. Additionally, $10 \mathrm{HWMs}$ were located in low-lying areas separated from these streams. Nine cross sections were created from these HWMs to generate the flood-elevation surface for these areas. The two flood-elevation surfaces were then combined. The HWMs ranged in elevation from $142.7 \mathrm{ft}$ near Capri Drive to $177.9 \mathrm{ft}$ in a low-lying area on Clematis Trail. The flood-inundation map for this location is shown in figure 2-20.

\section{Effects and Damages of the Flood of October 2015}

During October 2015, flooding on numerous streams and rivers in the central and coastal parts of South Carolina resulted in at least 17 fatalities. In the rural counties, conservative estimates of agricultural losses are expected to be at least $\$ 300$ million, and total damages will likely exceed $\$ 1$ billion (Feaster and others, 2015).

\section{Summary}

During October 1-5, 2015, flooding occurred on numerous streams and rivers in the central and coastal areas of South Carolina. The U.S. Geological Survey (USGS) documented 602 high-water marks during the period October 7 to 16, and 50 additional high-water marks were documented later in October. The high-water marks were used to create 20 maps showing the areas of inundation in 12 communities. Additionally, the depth of the water in the mapped inundated areas was calculated, and a water depth raster was created. The flood-inundation maps, water depth rasters, and mapping boundaries are all available as downloadable data. Flood-peak gage heights, peak streamflows, and estimated annual exceedance probabilities were calculated for eight USGS streamgages located within the inundation map areas. Additional information, including a download portal for high-water mark information, can be found on the USGS Appalachian Floods and Hurricane Joaquin Web page at http://water.usgs.gov/floods/events/2015/Joaquin/. 


\section{Acknowledgments}

The authors would like to acknowledge the Federal Emergency Management Agency Region IV for providing the funding for this project.

Also we would like to acknowledge the following individuals who located and surveyed the high-water marks: Dominick Antolino, Trent Baldwin, David Burt, Jessica Cain, Andy Caldwell, Kerry Caslow, Frank Chapelle, Greg Cherry, Brandon Cobb, Tom Cuffney, Cal Day, Sean Egen, John "Duke" Erbland, Jonathan Evans, Fred Falls, Jason Fine, Sharon Fitzgerald, Tony Gotvald, Jonathan Graham, Wladmir Guimaraes, Laura Gurley, Matthew Gyves, Don Hampton, Stephen Harden, Floyd Hartsfield, Bill Hazell, Scott Hedgecock, Chris Henry, Nick Henry, Ryan Hollis, Brad Huffman, Elliott Jones, Travis Knight, Daniel Kobzar, Tim Lanier, Terry Middleton, Doug Nagle, Matthew Petkewich, Kevin Reyes, Mark Roland, Chris Smith, Erik Staub, John Storm, Whitney Stringfield, Edward Swofford, Benjamin Thepaut, Lynn Torak, Bentley Walton, Curtis Weaver, Corey Whittaker, and Jonathan Willis.

\section{References Cited}

Badr, A.W., Wachob, Andrew, and Gellici, J.A., 2004, South Carolina water plan ( $2 \mathrm{~d}$ ed.): South Carolina Department of Natural Resources, Land, Water and Conservation Division, $120 \mathrm{p}$.

Cooke, C.W., 1936, Geology of the Coastal Plain of South Carolina: U.S. Geological Survey Bulletin 867, 196 p.

Feaster, T.D., Gotvald, A.J., and Weaver, J.C., 2009, Magnitude and frequency of rural floods in the Southeastern United States, 2006-Volume 3, South Carolina: U.S. Geological Survey Scientific Investigations Report 2009-5156, 226 p.

Feaster, T.D., Gotvald, A.J., and Weaver, J.C., 2014, Methods for estimating the magnitude and frequency of floods for urban and small, rural streams in Georgia, South Carolina, and North Carolina, 2011 (ver. 1.1, March 2014): U.S. Geological Survey Scientific Investigations Report 2014-5030, 104 p., accessed December 9, 2015, at http://dx.doi.org/10.3133/sir20145030.

Feaster, T.D., Shelton, J.M., and Robbins, J.C., 2015, Preliminary peak stage and streamflow data at selected USGS streamgaging stations for the South Carolina flood of October 2015 (ver. 1.1, November 2015): U.S. Geological Survey Open-File Report 2015-1201, 19 p., accessed December 9, 2015, at http://dx.doi.org/ $10.3133 /$ ofr20151201.
Federal Emergency Management Agency, 2001, Flood insurance study, Richland County, South Carolina, and incorporated areas: Washington, D.C., Federal Emergency Management Agency.

Flynn, K.M., Kirby, W.H., and Hummel, P.R., 2006, User's manual for program PeakFQ, annual flood-frequency analysis using Bulletin 17B guidelines: U.S. Geological Survey Techniques and Methods, book 4, chap. B4, 42 p.

Interagency Advisory Committee on Water Data, 1982, Guidelines for determining flood flow frequency, Bulletin 17B of the Hydrology Subcommittee: U.S. Geological Survey, Office of Water Data Coordination, 28 p., 14 app., 1 pl.

Langbein, W.B., and Iseri, K.T., 1960, General introduction and hydrologic definitions, Manual of hydrology_-Part 1. General surface-water techniques: U.S. Geological Survey Water-Supply Paper 1541-A, 29 p.

Mason, R.R., Jr., 2012, Computation of annual exceedance probability (AEP) for characterization of observed flood peaks: U.S. Geological Survey Office of Surface Water Technical Memorandum 2013.01, accessed December 9, 2015, at http://water.usgs.gov/admin/ memo/SW/sw13.01.pdf.

National Oceanic and Atmospheric Administration, 2015, Climate data online, accessed October 8, 2015, at http://www.ncdc.noaa.gov/climatenormals/clim60/ states/Clim_SC_01.pdf.

Omernik, J.M., 1987 (revised 2002), Ecoregions of the conterminous United States: Annals of the Association of American Geographers, v. 77, no. 1, p. 118-125, map scale $1: 7,500,000$.

Rydlund, P.H., Jr., and Densmore, B.K., 2012, Methods of practice and guidelines for using survey-grade global navigation satellite systems (GNSS) to establish vertical datum in the United States Geological Survey: U.S. Geological Survey Techniques and Methods, book 11, chap. D1, 102 p. with appendixes.

Veilleux, A.G., Cohn, T.A., Flynn, K.M., Mason, R.R., Jr., and Hummel, P.R., 2014, Estimating magnitude and frequency of floods using the PeakFQ 7.0 program: U.S. Geological Survey Fact Sheet 2013-3108, 2 p., accessed December 9, 2015, at http://dx.doi.org/10.3133/fs20133108. 


\section{Glossary}

The following definitions, except where noted, are from Langbein and Iseri (1960).

cubic feet per second A unit expressing rates of discharge. One cubic foot per second is equal to the discharge of a stream of rectangular cross section, 1 foot wide and 1 foot deep, flowing water an average velocity of 1 foot per second.

flood peak The highest value of the stage or discharge attained by a flood - thus, peak stage or peak discharge. Flood crest has nearly the same meaning, but because it connotes the top of the flood wave, it is properly used only in referring to stage - thus, crest stage, but not crest discharge.

flood probability The probability that a given event magnitude will be exceeded or equaled in any given year. Flood probability is directly related to recurrence interval. For example, there is a 1-percent chance that the 100-year peak flow will be exceeded or equaled in any given year. A flood probability of 0.01 has a recurrence interval of 100 years. The recurrence interval corresponding to a particular flood probability is equal to one divided by the flood probability (Interagency Advisory Committee on Water Data, 1982).

gage height The water-surface elevation referred to some arbitrary gage datum. Gage height is often used interchangeably with the more general term stage although gage height is more appropriate when used with a reading on a streamgage.

recurrence interval (return period) The average interval of time within which the given flood will be equaled or exceeded once. The recurrence interval is directly related to the flood probability. The recurrence interval corresponding to a particular flood probability is equal to one divided by the flood probability. For example, a 100-year recurrence interval has a flood probability of 0.01 (Interagency Advisory Committee on Water Data, 1982).

stream A general term for a body of flowing water. In hydrology the term is generally applied to the water flowing in a natural channel as distinct from a canal.

streamflow The discharge that occurs in a natural channel. Although the term discharge can be applied to the flow of a canal, the word streamflow uniquely describes the discharge in a surface stream course.

streamgage For the purposes of this report, the term is used to denote a gaging station where a continuous record of gage height (stage), velocity, or other parameters are collected for the purpose of determining streamflow (Interagency Advisory Committee on Water Data, 1982). 
Appendix 1 
Appendix 1. High-water marks used to generate flood-inundation maps of selected areas affected by the flood of October 2015 in central and coastal South Carolina.

[Methods for data collection for high-water marks are described in Rydlund and Densmore, 2012. Horizontal coordinate information is referenced to the North American Datum of 1983 (NAD 83). Vertical coordinate information is referenced to the North American Vertical Datum of 1988 (NAVD 88).

Location descriptions and HWM notes may be truncated. Abbreviations: ID, identification; HWM, high-water mark; Un. trib., unnamed tributary. - , no data]

\begin{tabular}{|c|c|c|c|c|c|c|c|}
\hline HWM ID & Waterbody & Site ID & HWM type & $\begin{array}{l}\text { HWM } \\
\text { quality }\end{array}$ & HWM location description & Latitude & Longitude \\
\hline 11816 & Mingo Crk/Swamp & 15094 & Debris & Good & $\begin{array}{l}\text { Grey two story home with white trim at end } \\
\text { of road, with stable/kennel located beyond } \\
\text { (east of) hous }\end{array}$ & 33.59054 & -79.42964 \\
\hline 11818 & Black River & 15096 & Debris & Good & Near Browns Ferry Park & 33.54809 & -79.40178 \\
\hline 11819 & $\begin{array}{l}\text { Tributary of } \\
\text { Mingo Crk }\end{array}$ & 15097 & Debris & Good & $\begin{array}{l}\text { Rhews Pentacostal Holiness Church near } \\
\text { intersection with County Rd 5-22-37 }\end{array}$ & 33.57657 & -79.43286 \\
\hline 11831 & Black River & 15109 & Debris & Good & $\begin{array}{l}\text { Dunbar Rd, bridge over Black R, } 4 \text { pilings NW } \\
\text { of 1st power pole on NE side of road, SE side } \\
\text { of Black }\end{array}$ & 33.5468 & -79.36014 \\
\hline 11834 & Black River & 15112 & Mud & Good & $\begin{array}{l}\text { White one story home, } 500^{\prime} \mathrm{N} \text { of road, left } \\
\mathrm{d} / \mathrm{s} \text { side of river; 4-bay garage } 200 \mathrm{ft} \text { from } \\
\text { road in front }\end{array}$ & 33.51987 & -79.42791 \\
\hline 11835 & Choppee Crk & 15113 & Debris & Good & $\begin{array}{l}\text { Entrance Rustic Lane at east side of Choppee } \\
\text { Rd (Across from Rose Hill Rd) }\end{array}$ & 33.55956 & -79.34252 \\
\hline 11836 & Black River & 15114 & Debris & Good & $\begin{array}{l}\text { Canteen Ln off Choppee Rd, 120 ft past } \\
\text { Marg George Ln }\end{array}$ & 33.5337 & -79.34053 \\
\hline 11837 & Black River & 15115 & Seed line & Good & $\begin{array}{l}\text { Off Whitmine, off Postfoot Rd, which is } \\
\text { off SC51 }\end{array}$ & 33.5032 & -79.32213 \\
\hline 11838 & Black River & 15116 & Seed line & Good & $\begin{array}{l}\text { Two story dark green house, SE corner post } \\
\text { facing river }\end{array}$ & 33.50122 & -79.29665 \\
\hline 11812 & Big Dam Swamp & 15090 & Seed line & Good & Brick one story on south side of road; submerged & 33.5003 & -79.51535 \\
\hline 11813 & Big Dam Swamp & 15091 & Mud & Good & $\begin{array}{l}\text { South side of SC Hwy } 41 \text { County Line Rd } \\
\text { \#16100-16550 driveway with black fence/ } \\
\text { copper post tops; whit }\end{array}$ & 33.49868 & -79.53409 \\
\hline 11814 & Big Dam Swamp & 15092 & Debris & Good & $\begin{array}{l}\text { Submerged; near Wallace Cemetary, guard rail } \\
\text { on SE side of Hwy }\end{array}$ & 33.51551 & -79.49979 \\
\hline 11815 & Big Dam Swamp & 15093 & Debris & Good & $\begin{array}{l}\text { Intersection of County Line Rd and Garnette Dr, } \\
\text { south side of County Line Rd }\end{array}$ & 33.51621 & -79.49825 \\
\hline \multicolumn{8}{|c|}{ Ashley River near Charleston } \\
\hline 11250 & Church Creek & 14428 & Debris & Fair & $\begin{array}{l}\text { Center fence post of backyard fence, on left side } \\
\text { at dead end of Par Drive }\end{array}$ & 32.84315 & -80.078 \\
\hline 11251 & Church Creek & 14429 & Debris & Fair & On wall/fence at sidewalk entrance to garage & 32.84354 & -80.07808 \\
\hline 11252 & Church Creek & 14430 & Stain line & Fair & $\begin{array}{l}\text { Mark type not indicated, but noted as inside } \\
\text { mark...transferred outside?... Sharpie line on } \\
\text { mailbox, si }\end{array}$ & 32.84362 & -80.08128 \\
\hline 11253 & Church Creek & 14431 & Debris & Fair & $\begin{array}{l}\text { On mailbox post under mailbox, side facing } \\
\text { driveway }\end{array}$ & 32.84399 & -80.08182 \\
\hline 11254 & Church Creek & 14432 & Debris & Fair & $\begin{array}{l}\text { On small fence surrounding garbage can on side } \\
\text { of house }\end{array}$ & 32.84434 & -80.08244 \\
\hline
\end{tabular}


Appendix 1. High-water marks used to generate flood-inundation maps of selected areas affected by the flood of 0 ctober 2015 in central and coastal South Carolina.-Continued

[Methods for data collection for high-water marks are described in Rydlund and Densmore, 2012. Horizontal coordinate information is referenced to the North American Datum of 1983 (NAD 83). Vertical coordinate information is referenced to the North American Vertical Datum of 1988 (NAVD 88).

Location descriptions and HWM notes may be truncated. Abbreviations: ID, identification; HWM, high-water mark; Un. trib., unnamed tributary. -, no data]

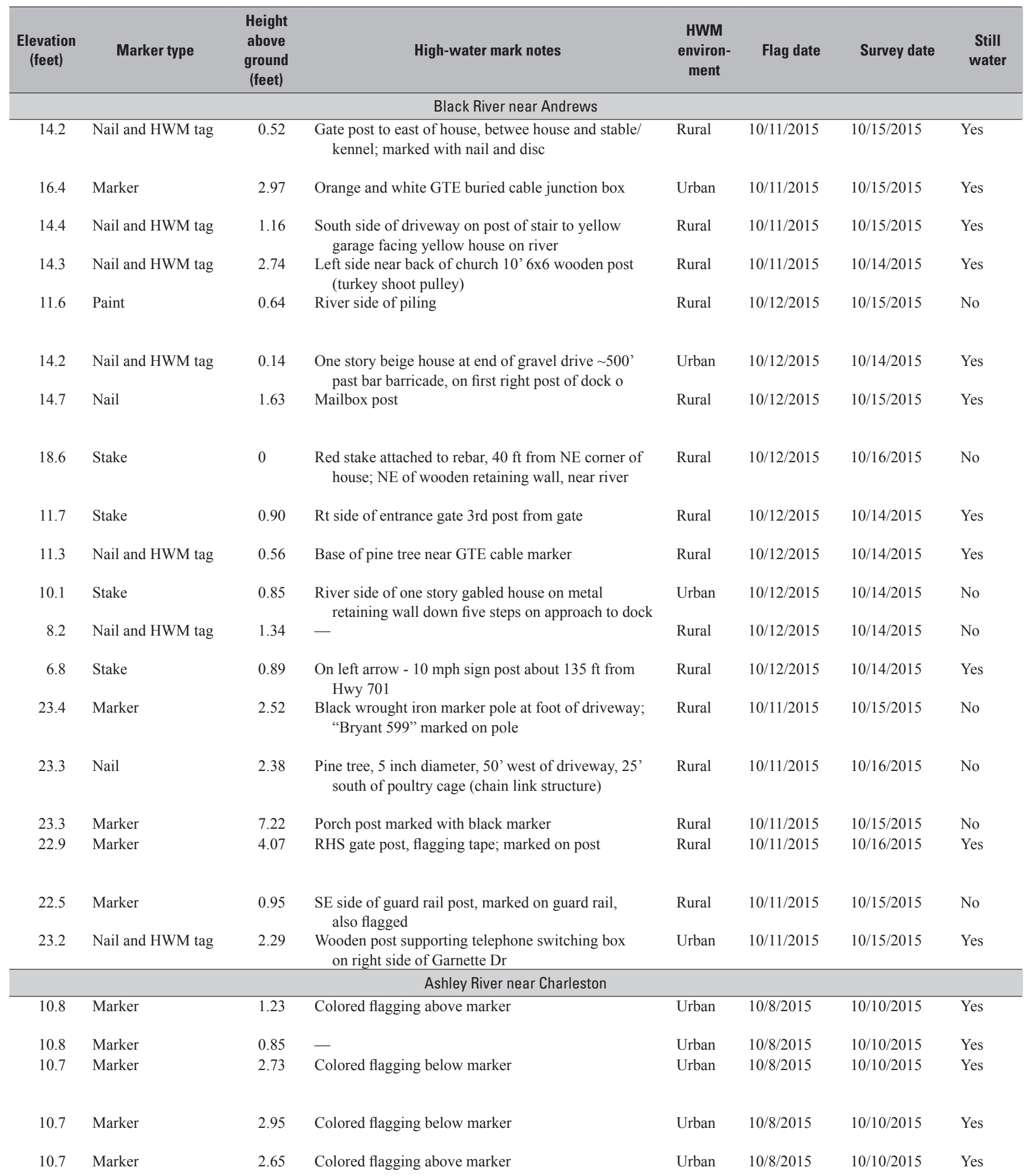


Appendix 1. High-water marks used to generate flood-inundation maps of selected areas affected by the flood of October 2015 in central and coastal South Carolina.-Continued

[Methods for data collection for high-water marks are described in Rydlund and Densmore, 2012. Horizontal coordinate information is referenced to the North American Datum of 1983 (NAD 83). Vertical coordinate information is referenced to the North American Vertical Datum of 1988 (NAVD 88).

Location descriptions and HWM notes may be truncated. Abbreviations: ID, identification; HWM, high-water mark; Un. trib., unnamed tributary. -, no data]

\begin{tabular}{|c|c|c|c|c|c|c|c|}
\hline HWM ID & Waterbody & Site ID & HWM type & $\begin{array}{l}\text { HWM } \\
\text { quality }\end{array}$ & HWM location description & Latitude & Longitude \\
\hline 11450 & Eagle Creek & 14748 & Seed line & Good & $\begin{array}{l}1013 \text { Harrison Rd, back yard side fence right } \\
\text { side of property }\end{array}$ & 32.96348 & -80.15023 \\
\hline 11451 & Ashley River & 14749 & Seed line & Good & $\begin{array}{l}\text { Bacons Bridge Rd (Hwy 16S bridge) Utility } \\
\text { poll } 300 \mathrm{ft} \text { from bridge }\end{array}$ & 32.95881 & -80.2004 \\
\hline 11452 & Ashley River & 14750 & Seed line & Good & $\begin{array}{l}\text { Hwy } 16 \mathrm{~S}-\text { Bacons Bridge Rd. End of white } \\
\text { picket fence }\end{array}$ & 32.95112 & -80.20218 \\
\hline 11453 & Ashley River & 14751 & Seed line & Good & 129 History Lane-Hwy 61. Alligators sign & 32.94635 & -80.24002 \\
\hline 11454 & Ashley River & 14752 & Seed line & Good & Cane Acre Rd, utility pole $30 \mathrm{ft}$ from road & 32.95828 & -80.26158 \\
\hline 11455 & Ashley River & 14753 & Debris & Good & $\begin{array}{l}1049 \text { Blockade Runner Pkwy, headwall near } \\
\text { kids playground }\end{array}$ & 32.96746 & -80.2473 \\
\hline 11330 & Ashley River & 14508 & Seed line & Good & SC-DOR-505; side wooden fence near garage & 32.9543 & -80.1859 \\
\hline 11331 & Ashley River & 14509 & Seed line & Good & $\begin{array}{l}\text { SC-DOR-506; fence at right property line; } \\
\text { bottom of fence at S of property line }\end{array}$ & 32.95413 & -80.18375 \\
\hline 11332 & Ashley River & 14510 & Seed line & Fair & $\begin{array}{l}\text { SC-DOR-507; 3rd maibox, post on mailbox } \\
\text { \#104 Park Lane }\end{array}$ & 32.94933 & -80.168 \\
\hline 11333 & Ashley River & 14511 & Seed line & Fair & $\begin{array}{l}\text { SC-DOR-508; } 6 \times 6 \text { post on back side of } \\
\text { dumpster enclosure }\end{array}$ & 32.94905 & -80.16168 \\
\hline 11334 & Ashley River & 14512 & Seed line & Good & $\begin{array}{l}\text { SC-DOR-509; Summer Bend on the Ashley } \\
\text { approx. 15-20 ft from dock follow line of flags }\end{array}$ & 32.9017 & -80.1179 \\
\hline 11335 & Ashley River & 14513 & Seed line & Good & SC-DOR-510 (no comments) & 32.89416 & -80.10246 \\
\hline 11686 & Popperdam Crk & 14963 & Seed line & Good & One story grey house with chain link fence & 32.94051 & -80.08222 \\
\hline 11687 & Popperdam Crk & 14964 & Seed line & Good & $\begin{array}{l}\text { Two story grey house/black trim on creekside of } \\
\text { road with weathered stockade fence on NW } \\
\text { side of pro }\end{array}$ & 32.94178 & -80.08063 \\
\hline 11689 & Popperdam Crk & 14966 & Seed line & Good & $\begin{array}{l}\text { One story brick house w/weathered stockade } \\
\text { fence on west side of yard }\end{array}$ & 32.94036 & -80.08139 \\
\hline 11690 & Popperdam Crk & 14967 & Seed line & Good & $\begin{array}{l}\text { One story brick/tan stucco, white/black trim, } \\
\text { with shed in backyard, north side of house }\end{array}$ & 32.94022 & -80.08209 \\
\hline 11691 & Popperdam Crk & 14968 & Seed line & Good & $\begin{array}{l}\text { One story brick house, backs up to channel, } \\
\text { dark red trim, " } 7771 \text { " above front door }\end{array}$ & 32.93849 & -80.08308 \\
\hline 11910 & Ashley River & 15248 & Mud & Good & - & 32.95262 & -80.17 \\
\hline 12150 & Church Creek & 15368 & Debris & Fair & On mailbox post under mailbox facing driveway & 32.8412 & -80.07828 \\
\hline 12151 & Church Creek & 15369 & Debris & Fair & On green electrical house on golf course & 32.84021 & -80.0788 \\
\hline 12152 & Church Creek & 15370 & Debris & Fair & On mailbox post facing driveway & 32.83483 & -80.0681 \\
\hline
\end{tabular}


Appendix 1. High-water marks used to generate flood-inundation maps of selected areas affected by the flood of 0 ctober 2015 in central and coastal South Carolina._- Continued

[Methods for data collection for high-water marks are described in Rydlund and Densmore, 2012. Horizontal coordinate information is referenced to the North American Datum of 1983 (NAD 83). Vertical coordinate information is referenced to the North American Vertical Datum of 1988 (NAVD 88).

Location descriptions and HWM notes may be truncated. Abbreviations: ID, identification; HWM, high-water mark; Un. trib., unnamed tributary. 一, no data]

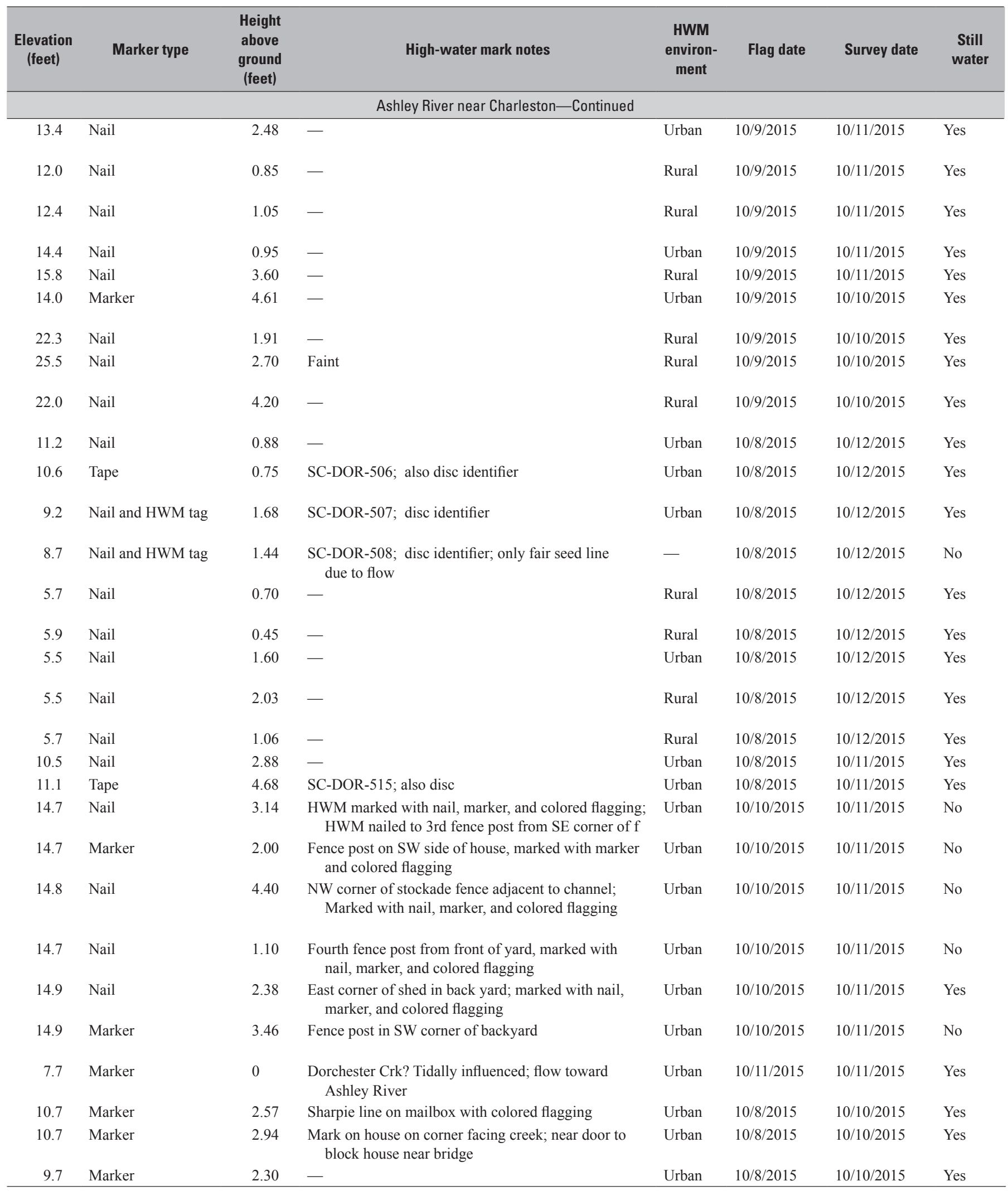


Appendix 1. High-water marks used to generate flood-inundation maps of selected areas affected by the flood of October 2015 in central and coastal South Carolina.-Continued

[Methods for data collection for high-water marks are described in Rydlund and Densmore, 2012. Horizontal coordinate information is referenced to the North American Datum of 1983 (NAD 83). Vertical coordinate information is referenced to the North American Vertical Datum of 1988 (NAVD 88).

Location descriptions and HWM notes may be truncated. Abbreviations: ID, identification; HWM, high-water mark; Un. trib., unnamed tributary. -, no data]

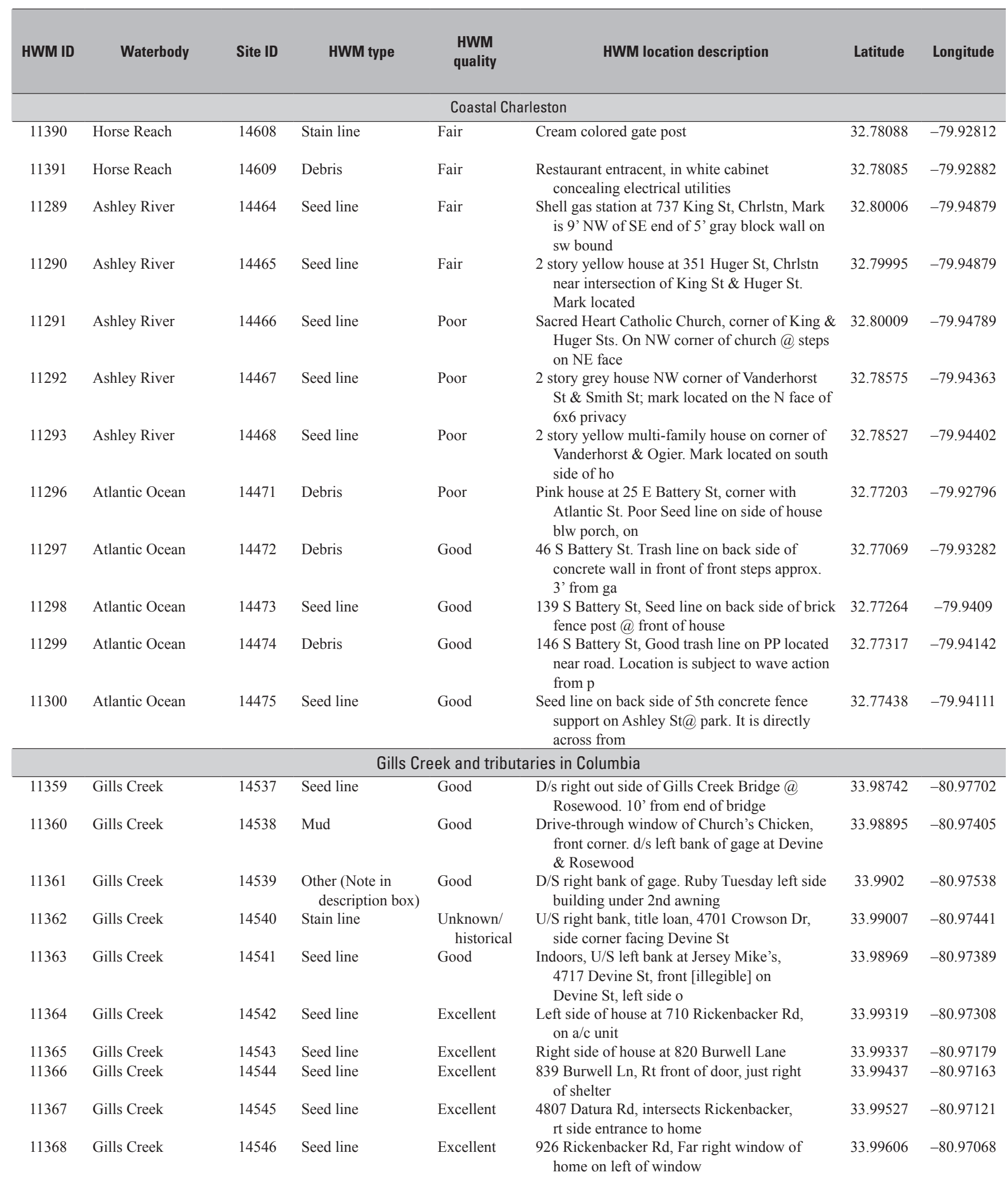


Appendix 1. High-water marks used to generate flood-inundation maps of selected areas affected by the flood of 0 ctober 2015 in central and coastal South Carolina.-Continued

[Methods for data collection for high-water marks are described in Rydlund and Densmore, 2012. Horizontal coordinate information is referenced to the North American Datum of 1983 (NAD 83). Vertical coordinate information is referenced to the North American Vertical Datum of 1988 (NAVD 88).

Location descriptions and HWM notes may be truncated. Abbreviations: ID, identification; HWM, high-water mark; Un. trib., unnamed tributary. - , no data]

\begin{tabular}{|c|c|c|c|c|c|c|c|}
\hline $\begin{array}{l}\text { Elevation } \\
\text { (feet) }\end{array}$ & Marker type & $\begin{array}{l}\text { Height } \\
\text { above } \\
\text { ground } \\
\text { (feet) }\end{array}$ & High-water mark notes & $\begin{array}{c}\text { HWM } \\
\text { environ- } \\
\text { ment }\end{array}$ & Flag date & Survey date & $\begin{array}{c}\text { Still } \\
\text { water }\end{array}$ \\
\hline 6.1 & - & 1.19 & $\begin{array}{l}\text { Linear dirt stain consistent with staff reports of water } \\
\text { encroachment into steps of restaurant }\end{array}$ & Urban & $10 / 8 / 2015$ & $10 / 12 / 2015$ & Yes \\
\hline 5.7 & - & 0 & Sharpie line of left side of cabinet & Urban & $10 / 8 / 2015$ & $10 / 12 / 2015$ & Yes \\
\hline 9.3 & Marker & 2.00 & $\begin{array}{l}\text { Flagging and marker, located just under third step to } \\
\text { the house }\end{array}$ & Urban & $10 / 8 / 2015$ & $10 / 17 / 2015$ & Yes \\
\hline 8.9 & Marker & 1.59 & Flagging \& marker & Urban & $10 / 8 / 2015$ & $10 / 17 / 2015$ & Yes \\
\hline 4.8 & Marker & 1.67 & $\begin{array}{l}\text { Flagging \& marker; located on S side of house, approx } \\
15^{\prime} \mathrm{E} \text { of } \mathrm{SW} \text { corner of house, below } 2 \text { windows } \mathrm{n}\end{array}$ & Urban & $10 / 8 / 2015$ & $10 / 12 / 2015$ & Yes \\
\hline 5.8 & Marker & 0.55 & - & Urban & $10 / 8 / 2015$ & $10 / 10 / 2015$ & Yes \\
\hline 5.3 & Marker & 0.55 & flagging on fence rail & Urban & $10 / 8 / 2015$ & $10 / 10 / 2015$ & Yes \\
\hline 4.9 & $\begin{array}{l}\text { Other (Note in } \\
\text { description box) }\end{array}$ & 1.05 & Pencil line & Urban & $10 / 8 / 2015$ & $10 / 10 / 2015$ & Yes \\
\hline 4.4 & Nail & 0.63 & - & Urban & $10 / 8 / 2015$ & $10 / 10 / 2015$ & Yes \\
\hline
\end{tabular}

\begin{tabular}{|c|c|c|c|c|c|c|c|}
\hline \multicolumn{8}{|c|}{ Gills Creek and tributaries in Columbia } \\
\hline 151.8 & Marker & 0 & 0.17 above ledge, 0.6 below concrete handrail & Urban & $10 / 8 / 2015$ & $10 / 12 / 2015$ & $\mathrm{No}$ \\
\hline 155.9 & Marker & 2.40 & 2.4 above road & Urban & $10 / 8 / 2015$ & $10 / 13 / 2015$ & No \\
\hline 155.0 & Marker & 0.50 & Mudline and stain & Urban & $10 / 8 / 2015$ & $10 / 13 / 2015$ & No \\
\hline 155.3 & Marker & 4.80 & - & Urban & $10 / 8 / 2015$ & $10 / 13 / 2015$ & No \\
\hline 155.3 & Marker & 5.30 & - & Urban & $10 / 8 / 2015$ & $10 / 13 / 2015$ & No \\
\hline 158.1 & Marker & 0.70 & - & Urban & $10 / 8 / 2015$ & $10 / 13 / 2015$ & No \\
\hline 158.4 & Marker & 6.40 & - & Urban & $10 / 8 / 2015$ & $10 / 13 / 2015$ & No \\
\hline 159.1 & Marker & 11.40 & $\begin{array}{l}6.36 \text { ' above brick window ledge (black square on } \\
\text { brick) or 11.4' above ground }\end{array}$ & Urban & $10 / 8 / 2015$ & $10 / 13 / 2015$ & No \\
\hline 159.2 & Marker & 6.70 & $5.7^{\prime}$ above porch, $6.7^{\prime}$ above ground & Riverine & $10 / 8 / 2015$ & $10 / 13 / 2015$ & No \\
\hline 159.4 & Marker & 4.80 & - & Urban & $10 / 8 / 2015$ & $10 / 13 / 2015$ & $\mathrm{No}$ \\
\hline
\end{tabular}


Appendix 1. High-water marks used to generate flood-inundation maps of selected areas affected by the flood of October 2015 in central and coastal South Carolina.-Continued

[Methods for data collection for high-water marks are described in Rydlund and Densmore, 2012. Horizontal coordinate information is referenced to the North American Datum of 1983 (NAD 83). Vertical coordinate information is referenced to the North American Vertical Datum of 1988 (NAVD 88).

Location descriptions and HWM notes may be truncated. Abbreviations: ID, identification; HWM, high-water mark; Un. trib., unnamed tributary. -, no data]

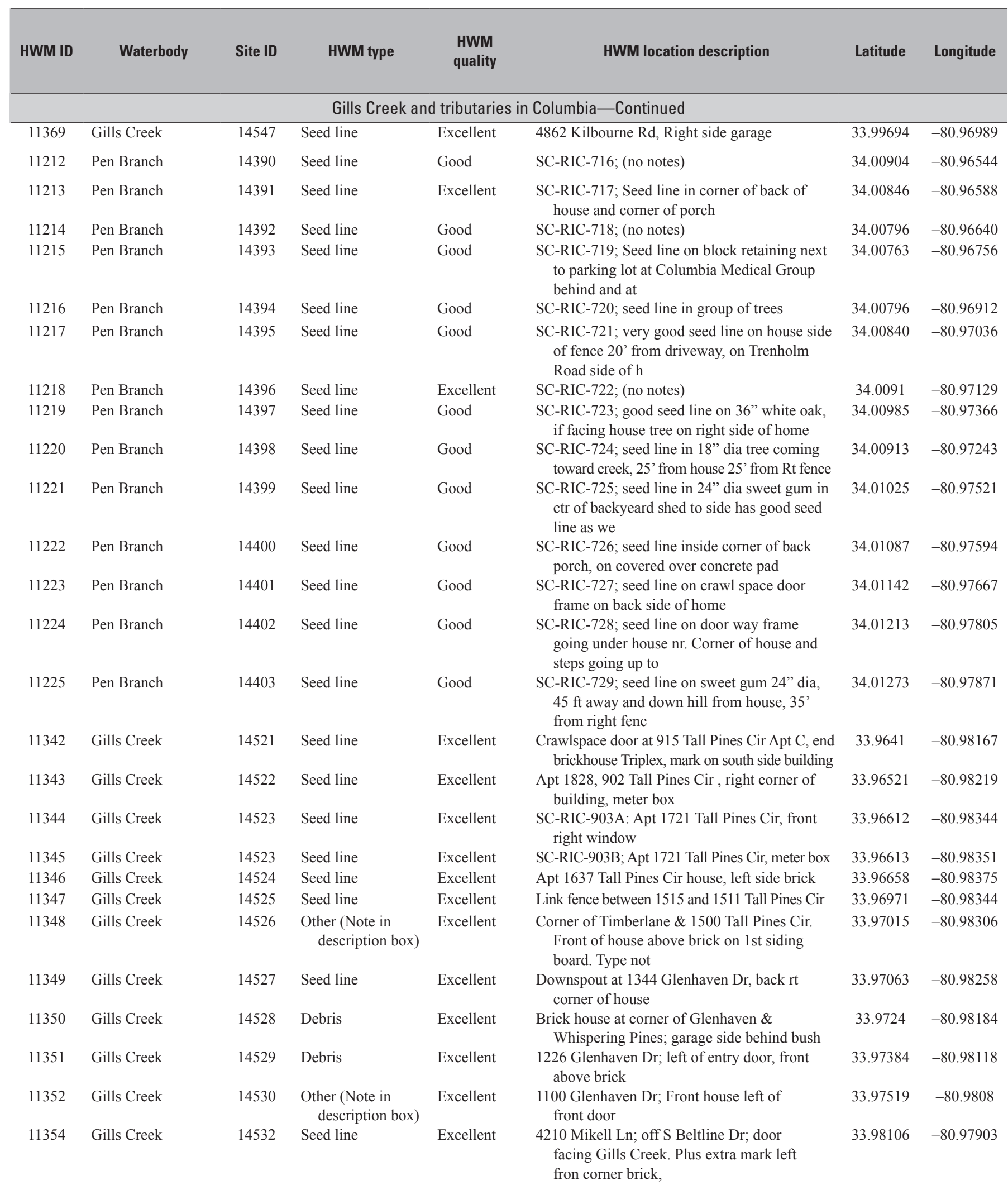


Appendix 1. High-water marks used to generate flood-inundation maps of selected areas affected by the flood of October 2015 in central and coastal South Carolina.-Continued

[Methods for data collection for high-water marks are described in Rydlund and Densmore, 2012. Horizontal coordinate information is referenced to the North American Datum of 1983 (NAD 83). Vertical coordinate information is referenced to the North American Vertical Datum of 1988 (NAVD 88).

Location descriptions and HWM notes may be truncated. Abbreviations: ID, identification; HWM, high-water mark; Un. trib., unnamed tributary. -, no data]

\begin{tabular}{|c|c|c|c|c|c|c|c|}
\hline $\begin{array}{c}\text { Elevation } \\
\text { (feet) }\end{array}$ & Marker type & $\begin{array}{c}\text { Height } \\
\text { above } \\
\text { ground } \\
\text { (feet) }\end{array}$ & High-water mark notes & $\begin{array}{c}\text { HWM } \\
\text { environ- } \\
\text { ment }\end{array}$ & Flag date & Survey date & $\begin{array}{l}\text { Still } \\
\text { water }\end{array}$ \\
\hline 159.6 & Marker & 4.90 & - & Urban & $10 / 8 / 2015$ & $10 / 13 / 2015$ & No \\
\hline 161.7 & Nail & 2.99 & Also colored flagging & Urban & $10 / 8 / 2015$ & $10 / 13 / 2015$ & No \\
\hline 161.9 & Marker & 2.95 & Also colored flagging & Urban & $10 / 8 / 2015$ & $10 / 13 / 2015$ & No \\
\hline 163.5 & Marker & 1.89 & Also colored flagging and spray paint & Urban & $10 / 8 / 2015$ & $10 / 13 / 2015$ & No \\
\hline 165.3 & Nail & 3.00 & Also colored flagging and spray paint & Urban & $10 / 8 / 2015$ & $10 / 13 / 2015$ & No \\
\hline 173.0 & Nail & 5.94 & Also colored flagging & Urban & $10 / 8 / 2015$ & $10 / 14 / 2015$ & No \\
\hline 175.2 & Nail & 3.72 & Also colored flagging & Urban & $10 / 8 / 2015$ & $10 / 14 / 2015$ & No \\
\hline 176.4 & Nail & 1.07 & $\begin{array}{l}\text { HWM measured above raised patio; also colored } \\
\text { flagging }\end{array}$ & Urban & $10 / 8 / 2015$ & $10 / 14 / 2015$ & No \\
\hline 178.5 & Nail & 2.42 & Also colored flagging & Urban & $10 / 8 / 2015$ & $10 / 13 / 2015$ & No \\
\hline 185.8 & Nail & 5.09 & Also colored flagging & Urban & $10 / 8 / 2015$ & $10 / 13 / 2015$ & No \\
\hline 148.4 & Marker & 5.20 & - & Urban & $10 / 8 / 2015$ & $10 / 12 / 2015$ & No \\
\hline 148.4 & Marker & 5.30 & - & Urban & $10 / 8 / 2015$ & $10 / 12 / 2015$ & No \\
\hline 148.5 & Marker & 1.32 & - & Urban & $10 / 8 / 2015$ & $10 / 12 / 2015$ & No \\
\hline 148.5 & Marker & 0.40 & - & Urban & $10 / 8 / 2015$ & $10 / 12 / 2015$ & No \\
\hline 148.5 & Marker & 6.60 & Type not noted & Urban & $10 / 8 / 2015$ & $10 / 12 / 2015$ & No \\
\hline 148.6 & Marker & 3.20 & - & Urban & $10 / 8 / 2015$ & $10 / 12 / 2015$ & No \\
\hline 148.9 & Marker & 4.60 & - & Urban & $10 / 8 / 2015$ & $10 / 12 / 2015$ & No \\
\hline 148.8 & Marker & 0.90 & Height is above wood sill on top of brick & Urban & $10 / 8 / 2015$ & $10 / 12 / 2015$ & No \\
\hline 149.0 & Marker & 5.80 & Seed and debris line' 5.8 above grd, 3.95 above step & Urban & $10 / 8 / 2015$ & $10 / 12 / 2015$ & No \\
\hline 149.5 & Marker & 2.80 & - & Urban & $10 / 8 / 2015$ & $10 / 12 / 2015$ & No \\
\hline
\end{tabular}


Appendix 1. High-water marks used to generate flood-inundation maps of selected areas affected by the flood of October 2015 in central and coastal South Carolina.-Continued

[Methods for data collection for high-water marks are described in Rydlund and Densmore, 2012. Horizontal coordinate information is referenced to the North American Datum of 1983 (NAD 83). Vertical coordinate information is referenced to the North American Vertical Datum of 1988 (NAVD 88).

Location descriptions and HWM notes may be truncated. Abbreviations: ID, identification; HWM, high-water mark; Un. trib., unnamed tributary. -, no data]

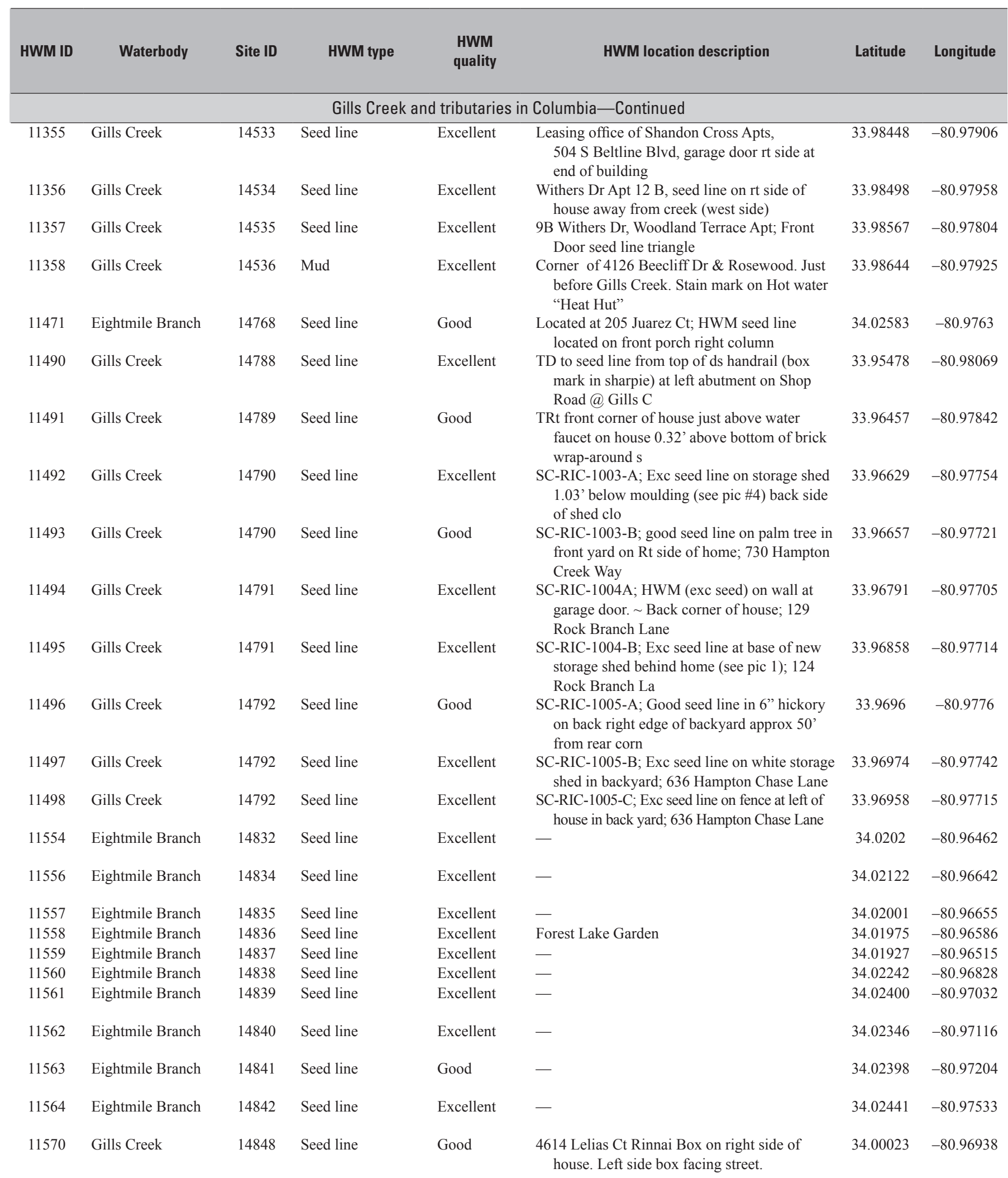


Appendix 1. High-water marks used to generate flood-inundation maps of selected areas affected by the flood of 0 ctober 2015 in central and coastal South Carolina.-Continued

[Methods for data collection for high-water marks are described in Rydlund and Densmore, 2012. Horizontal coordinate information is referenced to the North American Datum of 1983 (NAD 83). Vertical coordinate information is referenced to the North American Vertical Datum of 1988 (NAVD 88).

Location descriptions and HWM notes may be truncated. Abbreviations: ID, identification; HWM, high-water mark; Un. trib., unnamed tributary. -, no data]

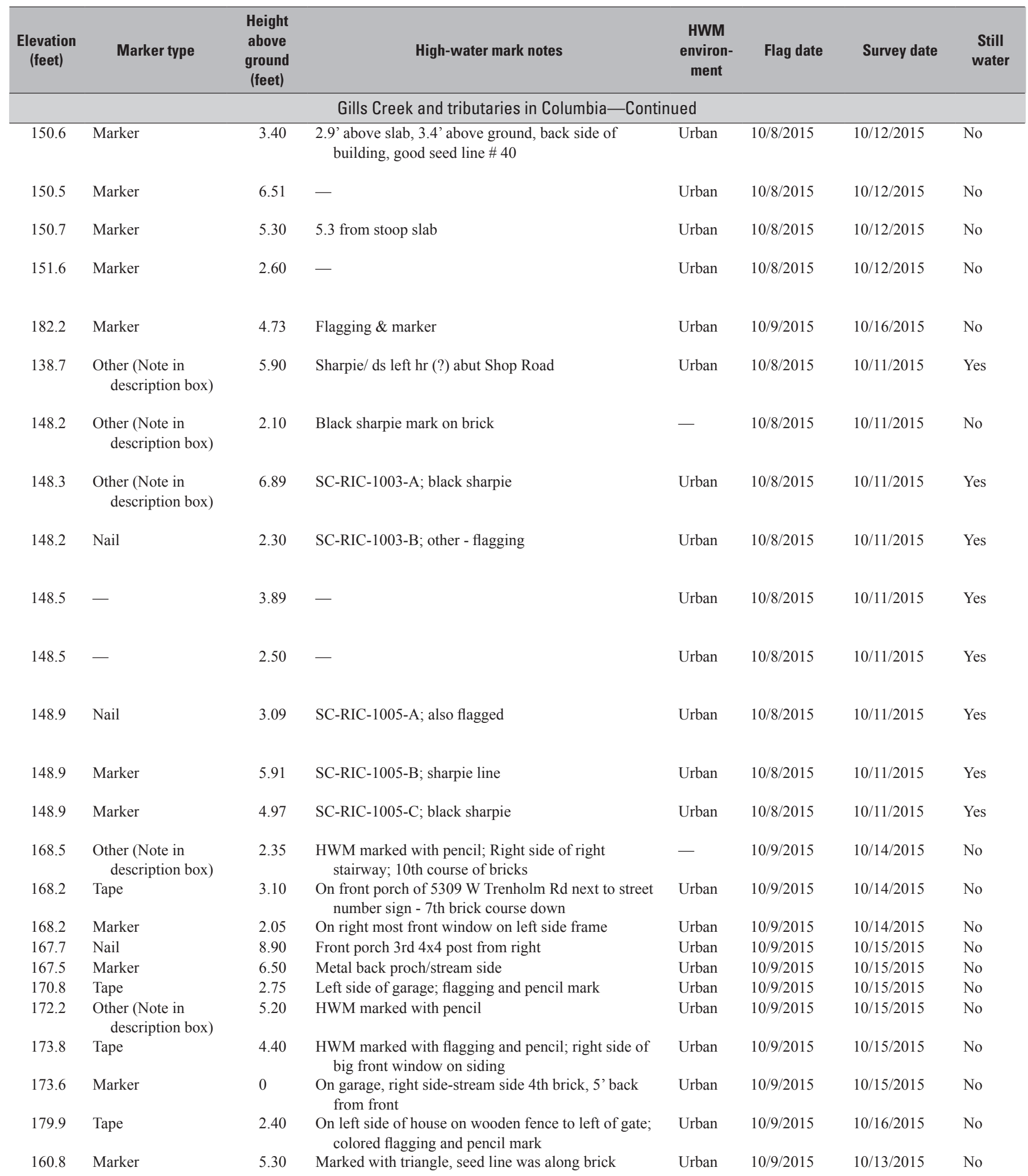


Appendix 1. High-water marks used to generate flood-inundation maps of selected areas affected by the flood of October 2015 in central and coastal South Carolina.-Continued

[Methods for data collection for high-water marks are described in Rydlund and Densmore, 2012. Horizontal coordinate information is referenced to the North American Datum of 1983 (NAD 83). Vertical coordinate information is referenced to the North American Vertical Datum of 1988 (NAVD 88).

Location descriptions and HWM notes may be truncated. Abbreviations: ID, identification; HWM, high-water mark; Un. trib., unnamed tributary. -, no data]

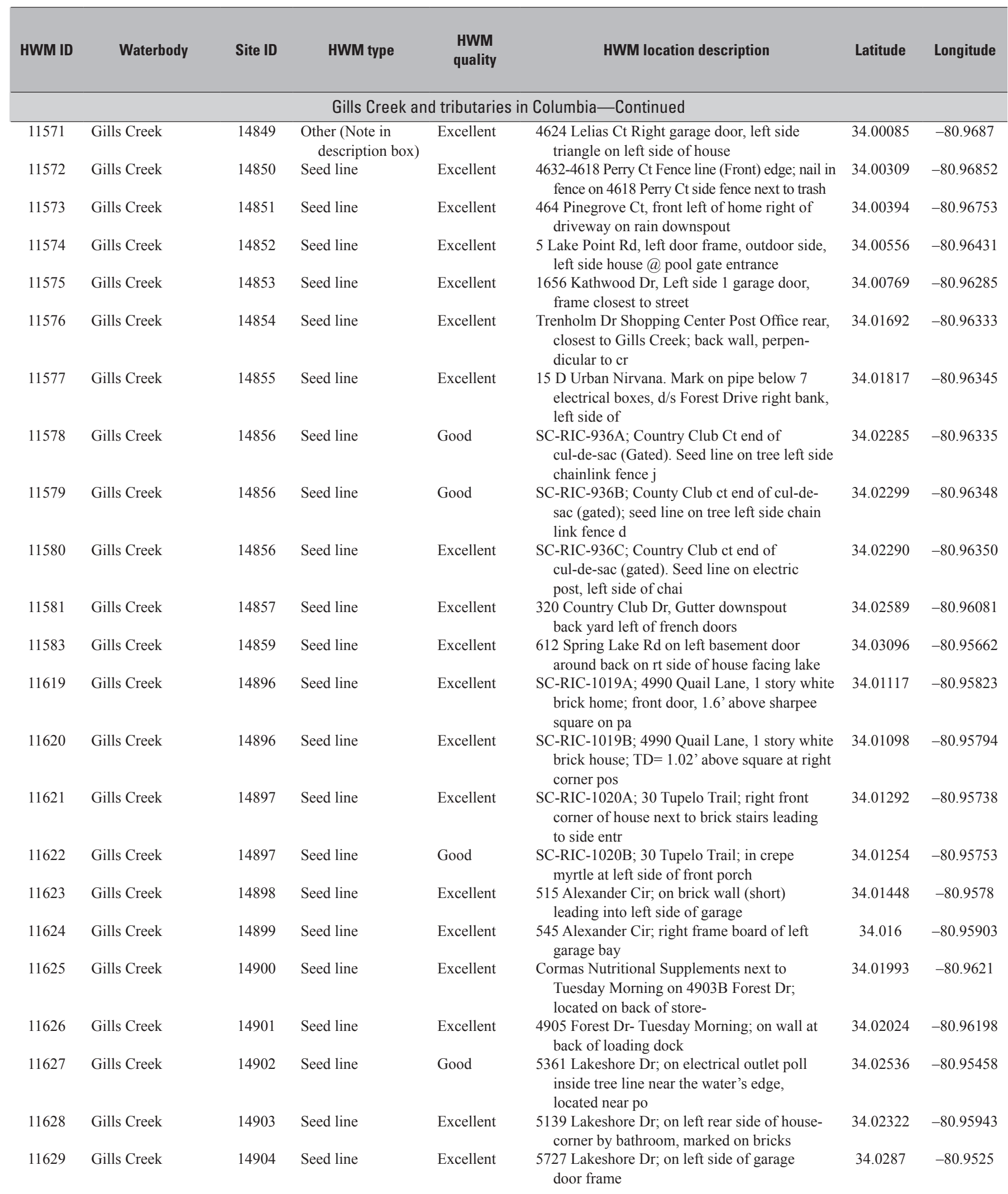


Appendix 1. High-water marks used to generate flood-inundation maps of selected areas affected by the flood of 0 ctober 2015 in central and coastal South Carolina.-Continued

[Methods for data collection for high-water marks are described in Rydlund and Densmore, 2012. Horizontal coordinate information is referenced to the North American Datum of 1983 (NAD 83). Vertical coordinate information is referenced to the North American Vertical Datum of 1988 (NAVD 88).

Location descriptions and HWM notes may be truncated. Abbreviations: ID, identification; HWM, high-water mark; Un. trib., unnamed tributary. - , no data]

\begin{tabular}{|c|c|c|c|c|c|c|c|}
\hline $\begin{array}{c}\text { Elevation } \\
\text { (feet) }\end{array}$ & Marker type & $\begin{array}{c}\text { Height } \\
\text { above } \\
\text { ground } \\
\text { (feet) }\end{array}$ & High-water mark notes & $\begin{array}{c}\text { HWM } \\
\text { environ- } \\
\text { ment }\end{array}$ & Flag date & Survey date & $\begin{array}{c}\text { Still } \\
\text { water }\end{array}$ \\
\hline 160.8 & Marker & 0 & Seed \& mudline, 3.8 ' above cement floor slab & Urban & $10 / 9 / 2015$ & $10 / 13 / 2015$ & No \\
\hline 160.9 & Nail & 1.60 & Flagging \& nail & Urban & $10 / 9 / 2015$ & $10 / 13 / 2015$ & No \\
\hline 160.8 & Marker & 0.10 & - & Urban & $10 / 9 / 2015$ & $10 / 13 / 2015$ & No \\
\hline 161.2 & Marker & 5.60 & See field notes for personal connection & Urban & $10 / 9 / 2015$ & $10 / 13 / 2015$ & No \\
\hline 164.8 & Marker & 2.70 & - & Urban & $10 / 9 / 2015$ & $10 / 13 / 2015$ & No \\
\hline 178.5 & Nail & 4.10 & Flagging \& nail & Urban & $10 / 9 / 2015$ & $10 / 14 / 2015$ & No \\
\hline 178.5 & Nail & 2.50 & Flagging \& nail & Urban & $10 / 9 / 2015$ & $10 / 14 / 2015$ & No \\
\hline 178.6 & Nail & 1.80 & Flagging \& nail & Urban & $10 / 9 / 2015$ & $10 / 14 / 2015$ & No \\
\hline 178.6 & Marker & 6.50 & - & Urban & $10 / 9 / 2015$ & $10 / 14 / 2015$ & No \\
\hline 178.7 & Marker & 0 & 1.3' above slab & Urban & $10 / 9 / 2015$ & $10 / 14 / 2015$ & No \\
\hline 164.3 & Nail & 2.12 & Nail \& flagging & Urban & $10 / 9 / 2015$ & $10 / 12 / 2015$ & Yes \\
\hline 164.3 & Marker & 2.39 & TD from top of wall to Sharpee arrow is 1.10 & Urban & $10 / 9 / 2015$ & $10 / 12 / 2015$ & Yes \\
\hline 164.4 & Marker & 4.94 & Tape up from square on concrete $=4.94$ & Urban & $10 / 9 / 2015$ & $10 / 12 / 2015$ & Yes \\
\hline 167.3 & Marker & 3.16 & Arrow and square on concrete & Urban & $10 / 9 / 2015$ & $10 / 12 / 2015$ & No \\
\hline 167.6 & Marker & 0 & Double peaks: 1 st $3.62^{\prime}, 2$ nd $2.55^{\prime}$ & Urban & $10 / 9 / 2015$ & $10 / 12 / 2015$ & No \\
\hline 178.6 & Nail & 3.07 & Nail \& flagging & Urban & $10 / 9 / 2015$ & $10 / 13 / 2015$ & No \\
\hline 178.6 & Marker & 1.86 & Marked with arrow in Sharpie & Urban & $10 / 9 / 2015$ & $10 / 13 / 2015$ & No \\
\hline 178.5 & Marker & 2.45 & Sharpie with arrow and square on concrete & Urban & $10 / 9 / 2015$ & $10 / 13 / 2015$ & No \\
\hline
\end{tabular}


Appendix 1. High-water marks used to generate flood-inundation maps of selected areas affected by the flood of October 2015 in central and coastal South Carolina._- Continued

[Methods for data collection for high-water marks are described in Rydlund and Densmore, 2012. Horizontal coordinate information is referenced to the North American Datum of 1983 (NAD 83). Vertical coordinate information is referenced to the North American Vertical Datum of 1988 (NAVD 88).

Location descriptions and HWM notes may be truncated. Abbreviations: ID, identification; HWM, high-water mark; Un. trib., unnamed tributary. -, no data]

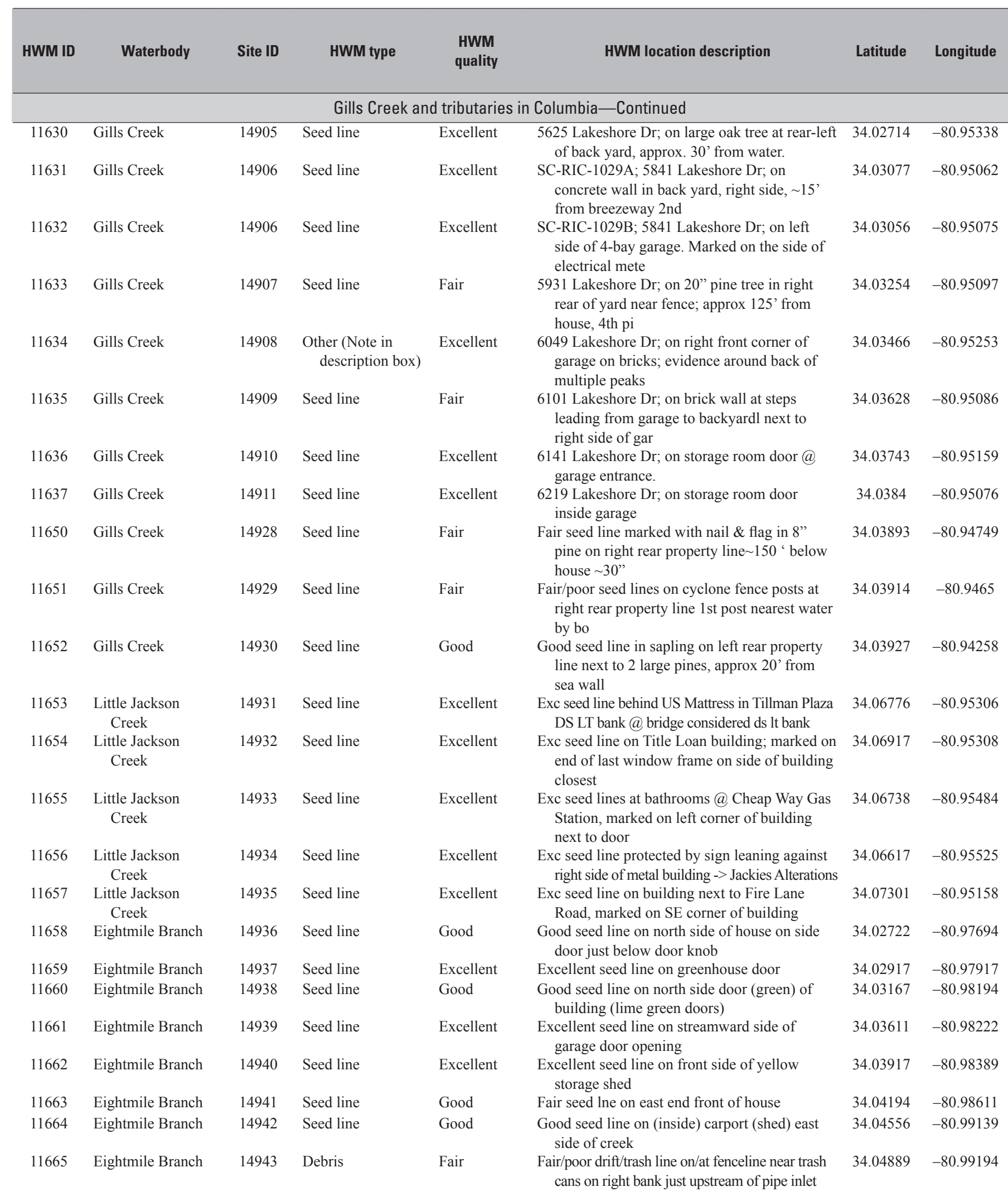


Appendix 1. High-water marks used to generate flood-inundation maps of selected areas affected by the flood of October 2015 in central and coastal South Carolina.-Continued

[Methods for data collection for high-water marks are described in Rydlund and Densmore, 2012. Horizontal coordinate information is referenced to the North American Datum of 1983 (NAD 83). Vertical coordinate information is referenced to the North American Vertical Datum of 1988 (NAVD 88).

Location descriptions and HWM notes may be truncated. Abbreviations: ID, identification; HWM, high-water mark; Un. trib., unnamed tributary. -, no data]

\begin{tabular}{|c|c|c|c|c|c|c|c|}
\hline $\begin{array}{l}\text { Elevation } \\
\text { (feet) }\end{array}$ & Marker type & $\begin{array}{c}\text { Height } \\
\text { above } \\
\text { ground } \\
\text { (feet) }\end{array}$ & High-water mark notes & $\begin{array}{l}\text { HWM } \\
\text { environ- } \\
\text { ment }\end{array}$ & Flag date & Survey date & $\begin{array}{c}\text { Still } \\
\text { water }\end{array}$ \\
\hline 178.6 & Nail & 4.78 & $\begin{array}{l}\text { Multiple bands- owner said levels fluctuated with } \\
\text { dam breaks }\end{array}$ & Urban & $10 / 9 / 2015$ & $10 / 13 / 2015$ & No \\
\hline 178.7 & Marker & 5.64 & - & Urban & $10 / 9 / 2015$ & $10 / 13 / 2015$ & No \\
\hline 178.7 & Marker & 5.35 & - & Urban & $10 / 9 / 2015$ & $10 / 13 / 2015$ & No \\
\hline 178.6 & Nail & 1.99 & Nail \& flagging & Urban & $10 / 9 / 2015$ & $10 / 13 / 2015$ & No \\
\hline 186.1 & Marker & 0.82 & $\begin{array}{l}\text { Sharpie arrow \& square marker; } \mathrm{TD}=0.68^{\prime} \text { above } \\
\text { square }\end{array}$ & Urban & $10 / 9 / 2015$ & $10 / 13 / 2015$ & No \\
\hline 186.1 & Marker & 0.60 & Sharpie arrow and square & Urban & $10 / 9 / 2015$ & $10 / 13 / 2015$ & No \\
\hline 191.6 & Nail & 2.40 & Also colored flagging & Urban & $10 / 10 / 2015$ & $10 / 14 / 2015$ & No \\
\hline 191.3 & Marker & 1.57 & $\# 1$ and $1.57(\# 2)$ & Riverine & $10 / 10 / 2015$ & $10 / 14 / 2015$ & No \\
\hline 191.6 & Nail & 1.89 & Also colored flagging & Urban & $10 / 10 / 2015$ & $10 / 14 / 2015$ & No \\
\hline 215.8 & Marker & 3.80 & Other: sharpie "arrow down to line" & Urban & $10 / 10 / 2015$ & $10 / 14 / 2015$ & No \\
\hline 218.8 & Marker & 3.66 & Other: sharpie "arrow down to line" & Urban & $10 / 10 / 2015$ & $10 / 14 / 2015$ & No \\
\hline 183.9 & Marker & 5.00 & also colored flagging & Urban & $10 / 10 / 2015$ & $10 / 15 / 2015$ & Yes \\
\hline 189.5 & Marker & 2.20 & Also colored flagging & Urban & $10 / 10 / 2015$ & $10 / 15 / 2015$ & Yes \\
\hline 202.6 & Marker & 2.30 & Also colored flagging & Urban & $10 / 10 / 2015$ & $10 / 15 / 2015$ & No \\
\hline 210.8 & Marker & 2.60 & Also colored flagging & Urban & $10 / 10 / 2015$ & $10 / 15 / 2015$ & Yes \\
\hline 219.5 & Marker & 2.20 & Also colored flagging & Urban & $10 / 10 / 2015$ & $10 / 15 / 2015$ & No \\
\hline 225.7 & Marker & 0.50 & Also colored flagging & Riverine & $10 / 10 / 2015$ & $10 / 15 / 2015$ & No \\
\hline 247.9 & Marker & 1.85 & Also colored flagging & Urban & $10 / 10 / 2015$ & $10 / 15 / 2015$ & No \\
\hline 257.5 & Nail & 0 & Also colored flagging, other: in tree root & Urban & $10 / 10 / 2015$ & $10 / 15 / 2015$ & No \\
\hline
\end{tabular}


Appendix 1. High-water marks used to generate flood-inundation maps of selected areas affected by the flood of October 2015 in central and coastal South Carolina.-Continued

[Methods for data collection for high-water marks are described in Rydlund and Densmore, 2012. Horizontal coordinate information is referenced to the North American Datum of 1983 (NAD 83). Vertical coordinate information is referenced to the North American Vertical Datum of 1988 (NAVD 88).

Location descriptions and HWM notes may be truncated. Abbreviations: ID, identification; HWM, high-water mark; Un. trib., unnamed tributary. -, no data]

\begin{tabular}{|c|c|c|c|c|c|c|c|}
\hline HWM ID & Waterbody & Site ID & HWM type & $\begin{array}{l}\text { HWM } \\
\text { quality }\end{array}$ & HWM location description & Latitude & Longitude \\
\hline 11666 & Eightmile Branch & 14944 & Seed line & Good & $\begin{array}{l}\text { Good seed line on rock faced building (busi- } \\
\text { ness), front west edge of building }\end{array}$ & 34.045 & -80.99028 \\
\hline 11670 & Wildcat Creek & 14948 & Seed line & Good & $\begin{array}{l}\text { Approx. } 80 \text { yards west of southbound lanes } \\
\text { of I-77; in 7" pine tree, on left bank. About } \\
15 \text { yards rig }\end{array}$ & 33.995 & -80.96163 \\
\hline 11671 & Wildcat Creek & 14949 & Seed line & Good & $\begin{array}{l}4963 \text { Fort Jackson Blvd; on glass door of } \\
\text { barber shop }\end{array}$ & 33.99529 & -80.957 \\
\hline 11672 & Wildcat Creek & 14950 & Seed line & Good & $\begin{array}{l}\text { Approx. } 50 \text { yards upstream Ft Jackson Blvd, } \\
15 \text { yards East of Kings Grant Dr. 15" sweet gum }\end{array}$ & 33.99473 & -80.95886 \\
\hline 11673 & Wildcat Creek & 14951 & Seed line & Fair & $\begin{array}{l}\text { SC-RIC-1104A; } 15 \text { yards east of gated entrance; } \\
1 \text { yard north of Kings Grant Dr. Oak tree }\end{array}$ & 33.99362 & -80.9558 \\
\hline 11700 & Jackson Creek & 14977 & Seed line & Good & Sharpie mark on corner of shop just off the carport & 34.06861 & -80.93661 \\
\hline 11701 & Jackson Creek & 14978 & Debris & Fair & $\begin{array}{l}\text { Nail in large split pine on downstream side } \\
\text { in middle of Bay Springs Road down near } \\
\text { water's edge }\end{array}$ & 34.06821 & -80.93528 \\
\hline 11702 & Jackson Creek & 14979 & Seed line & Good & $\begin{array}{l}\text { Sharpie and flagging on DS post of dock in rear } \\
\text { of house }\end{array}$ & 34.06821 & -80.93528 \\
\hline 11703 & Jackson Creek & 14980 & Seed line & Good & Nail in tree behind house. Marked with flagging & 34.07027 & -80.9351 \\
\hline 11704 & Jackson Creek & 14981 & Seed line & Good & $\begin{array}{l}\text { Sharpie mark and nail w/ flagging on primary } \\
\text { fence behind house on lake side of fence }\end{array}$ & 34.07563 & -80.92924 \\
\hline 11705 & Jackson Creek & 14982 & Seed line & Good & $\begin{array}{l}\text { Nail and disc in tree behind house. Marked } \\
\text { with flagging. }\end{array}$ & 34.07566 & -80.9259 \\
\hline 11682 & Jackson Creek & 14959 & Seed line & Fair & $\begin{array}{l}5 " \text { tree next to parking lot, } 100 \text { yards east of } \\
\text { Decker Blvd, near Boeshreen Resaturant }\end{array}$ & 34.06153 & -80.95195 \\
\hline 11684 & Jackson Creek & 14961 & Seed line & Good & $\begin{array}{l}\text { Tulip poplar tree east of O’Neil Court road; } \\
40 \mathrm{ft} \text { off road }\end{array}$ & 34.06334 & -80.9488 \\
\hline 11582 & Gills Creek & 14858 & Seed line & Good & $\begin{array}{l}340 \text { Country Club Dr; Forest Lake Club end of } \\
\text { Country Club Dr. Pool side entrance around } \\
\text { back (facing }\end{array}$ & 34.02699 & -80.95847 \\
\hline 11584 & Gills Creek & 14860 & Seed line & Excellent & $\begin{array}{l}628 \text { Spring Lake Rd, back entrance of basement } \\
\text { around back, Back right side of house }\end{array}$ & 34.03202 & -80.95593 \\
\hline 11585 & Gills Creek & 14861 & Seed line & Excellent & $\begin{array}{l}3850 \text { Northshore Rd, Inside door under deck, } \\
\text { left side of house }\end{array}$ & 34.04136 & -80.95231 \\
\hline 11586 & Gills Creek & 14862 & Seed line & Good & $\begin{array}{l}3654 \text { Northshore Rd, cinderblock column, } \\
\text { backyard, between neighbor's yar boundary. } \\
\text { Edge of Lake. Lef }\end{array}$ & 34.04025 & -80.94698 \\
\hline 11587 & Gills Creek & 14863 & Seed line & Excellent & $\begin{array}{l}3446 \text { Northshore Rd, shed in back yard, left side } \\
\text { of yard, right side of entrance door }\end{array}$ & 34.03957 & -80.94106 \\
\hline 11588 & Jackson Creek & 14864 & Seed line & Good & Residence & 34.06499 & -80.94435 \\
\hline
\end{tabular}


Appendix 1. High-water marks used to generate flood-inundation maps of selected areas affected by the flood of October 2015 in central and coastal South Carolina.-Continued

[Methods for data collection for high-water marks are described in Rydlund and Densmore, 2012. Horizontal coordinate information is referenced to the North American Datum of 1983 (NAD 83). Vertical coordinate information is referenced to the North American Vertical Datum of 1988 (NAVD 88).

Location descriptions and HWM notes may be truncated. Abbreviations: ID, identification; HWM, high-water mark; Un. trib., unnamed tributary. - , no data]

\begin{tabular}{|c|c|c|c|c|c|c|c|}
\hline $\begin{array}{c}\text { Elevation } \\
\text { (feet) }\end{array}$ & Marker type & $\begin{array}{c}\text { Height } \\
\text { above } \\
\text { ground } \\
\text { (feet) }\end{array}$ & High-water mark notes & $\begin{array}{c}\text { HWM } \\
\text { environ- } \\
\text { ment }\end{array}$ & Flag date & Survey date & $\begin{array}{c}\text { Still } \\
\text { water }\end{array}$ \\
\hline 247.8 & Marker & 1.70 & Also colored flagging & Urban & $10 / 10 / 2015$ & $10 / 15 / 2015$ & No \\
\hline 161.0 & Nail & 4.50 & Nail and flagging & Urban & $10 / 9 / 2015$ & $10 / 12 / 2015$ & No \\
\hline 164.7 & $\begin{array}{l}\text { Other (Note in } \\
\text { description box) }\end{array}$ & 1.60 & Marker, nail, and flagging & Urban & $10 / 9 / 2015$ & $10 / 12 / 2015$ & No \\
\hline 170.7 & Nail & 7.80 & Nail and flagging & - & $10 / 9 / 2015$ & $10 / 12 / 2015$ & No \\
\hline 192.5 & Nail & 6.00 & Nail and flagging & Urban & $10 / 9 / 2015$ & $10 / 13 / 2015$ & No \\
\hline 223.6 & Marker & 1.17 & Also colored flagging & Urban & $10 / 10 / 2015$ & $10 / 14 / 2015$ & Yes \\
\hline 227.5 & Nail & 1.85 & Also colored flagging & Urban & $10 / 10 / 2015$ & $10 / 14 / 2015$ & No \\
\hline 232.8 & Marker & 1.69 & Also colored flagging & Urban & $10 / 10 / 2015$ & $10 / 14 / 2015$ & No \\
\hline 225.7 & Nail & 1.22 & Also colored flagging & Urban & $10 / 10 / 2015$ & $10 / 14 / 2015$ & Yes \\
\hline 231.8 & Nail & 2.44 & Also colored flagging and marker & Urban & $10 / 10 / 2015$ & $10 / 14 / 2015$ & No \\
\hline 231.7 & Nail & 1.99 & Also colored flagging and disc & Urban & $10 / 10 / 2015$ & $10 / 14 / 2015$ & Yes \\
\hline 203.1 & Nail & 5.00 & Nail and flagging & Urban & $10 / 9 / 2015$ & $10 / 13 / 2015$ & No \\
\hline 205.5 & Nail & 5.40 & Nail and flagging & Urban & $10 / 9 / 2015$ & $10 / 14 / 2015$ & No \\
\hline 178.6 & Marker & 1.20 & - & Urban & $10 / 9 / 2015$ & $10 / 14 / 2015$ & No \\
\hline 178.7 & Marker & 0 & 3.5' above slab & Urban & $10 / 9 / 2015$ & $10 / 14 / 2015$ & No \\
\hline 192.2 & Marker & 2.00 & - & Urban & $10 / 9 / 2015$ & $10 / 14 / 2015$ & No \\
\hline 191.6 & Marker & 2.20 & - & Urban & $10 / 9 / 2015$ & $10 / 14 / 2015$ & No \\
\hline 191.5 & $\begin{array}{l}\text { Other (Note in } \\
\text { description box) }\end{array}$ & 2.00 & Mark type not specified & Urban & $10 / 9 / 2015$ & $10 / 14 / 2015$ & No \\
\hline 205.5 & Marker & 6.55 & $\begin{array}{l}\text { Seed line located on northeast corner of home on a } \\
\text { gutter downspout, marked with sharpie and flagged }\end{array}$ & Urban & $10 / 10 / 2015$ & $10 / 13 / 2015$ & No \\
\hline
\end{tabular}


Appendix 1. High-water marks used to generate flood-inundation maps of selected areas affected by the flood of 0 ctober 2015 in central and coastal South Carolina.-Continued

[Methods for data collection for high-water marks are described in Rydlund and Densmore, 2012. Horizontal coordinate information is referenced to the North American Datum of 1983 (NAD 83). Vertical coordinate information is referenced to the North American Vertical Datum of 1988 (NAVD 88).

Location descriptions and HWM notes may be truncated. Abbreviations: ID, identification; HWM, high-water mark; Un. trib., unnamed tributary. - , no data]

\begin{tabular}{|c|c|c|c|c|c|c|c|}
\hline HWM ID & Waterbody & Site ID & HWM type & $\begin{array}{l}\text { HWM } \\
\text { quality }\end{array}$ & HWM location description & Latitude & Longitude \\
\hline \multicolumn{8}{|c|}{ Gills Creek and tributaries in Columbia-Continued } \\
\hline 11589 & Jackson Creek & 14865 & Seed line & Fair & Residence & 34.07107 & -80.93881 \\
\hline 11590 & Jackson Creek & 14866 & Seed line & Good & - & 34.07093 & -80.93685 \\
\hline 11592 & $\begin{array}{l}\text { Jackson Creek } \\
\text { Tributary }\end{array}$ & 14868 & Seed line & Good & - & 34.07707 & -80.93606 \\
\hline 11593 & Jackson Creek & 14869 & Seed line & Good & - & 34.07311 & -80.9332 \\
\hline 11594 & Jackson Creek & 14870 & Seed line & Good & - & 34.07486 & -80.92946 \\
\hline 11611 & Eightmile Branch & 14889 & Seed line & Excellent & - & 34.02853 & -80.97939 \\
\hline 11612 & Eightmile Branch & 14890 & Seed line & Poor & $\begin{array}{l}\text { Covenant Rd fenceline on upstream right bank } \\
\text { for Recycling Facility on Robert Spring }\end{array}$ & 34.0313 & -80.982 \\
\hline 11613 & Eightmile Branch & 14891 & Seed line & Excellent & - & 34.03468 & -80.98211 \\
\hline 11614 & Eightmile Branch & 14892 & Seed line & Excellent & - & 34.03648 & -80.98244 \\
\hline 11615 & Eightmile Branch & 14893 & Seed line & Excellent & Split rancher & 34.03744 & -80.9828 \\
\hline 11617 & Gills Creek & 14895 & Seed line & Good & $\begin{array}{l}\text { SC-RIC-1018A; } 4779 \text { Heath Hill Rd, } 2 \text { story } \\
\text { brick home; right brick post of gate entrance } \\
\text { to back yard }\end{array}$ & 34.01052 & -80.95789 \\
\hline 11499 & Gills Creek & 14793 & Seed line & Excellent & $\begin{array}{l}\text { SC-RIC-1006-A; Exc seed line all around } \\
2 \text { story home. Measure at siding on Chimney } \\
\text { at right side of }\end{array}$ & 33.97135 & -80.97601 \\
\hline 11500 & Gills Creek & 14793 & Seed line & Excellent & $\begin{array}{l}\text { SC-RIC-1006-B; Exc seed line at front corner } \\
\text { of house at front door (pic \#1) at extension } \\
\text { of garage }\end{array}$ & 33.97136 & -80.97579 \\
\hline 11501 & Gills Creek & 14794 & Seed line & Excellent & $\begin{array}{l}\text { Exc seed line in back right corner of fence in } \\
\text { back yard }\end{array}$ & 33.97297 & -80.97577 \\
\hline 11502 & Gills Creek & 14795 & Seed line & Fair & $\begin{array}{l}\text { SC-RIC-1008-A; Fair seed line in } 20 " \text { pine } \\
\text { about } 100 \text { 'S of entrance to Hampton Courts } \\
\text { Apts across dra }\end{array}$ & 33.98024 & -80.97582 \\
\hline 11503 & Gills Creek & 14795 & Seed line & Fair & SC-RIC-1008-B; Fair seed line in 12" sweet gum & 33.98006 & -80.97565 \\
\hline 11504 & Gills Creek & 14796 & Seed line & Good & $\begin{array}{l}\text { Good seed line on siding at stairs of apt } 8 \text { inside } \\
\text { stairwell at } \mathrm{N} \text { wall }\end{array}$ & 33.98324 & -80.9752 \\
\hline 11505 & Gills Creek & 14797 & Seed line & Excellent & $\begin{array}{l}\text { SC-RIC-1010-A; } 4465 \text { Jackson Blvd; } 2 \text { story } \\
\text { brick duplex Northwest corner on side door } \\
\text { @ Gills Cr Brid }\end{array}$ & 33.99264 & -80.97126 \\
\hline 11506 & Gills Creek & 14797 & Seed line & Good & $\begin{array}{l}\text { SC-RIC-1010-B; Latter Day Saints Church } \\
\text { @ Jackson Blvd on ds Lf bank @ bridge } \\
\text { over Gills Creek; Good }\end{array}$ & 33.99181 & -80.97163 \\
\hline
\end{tabular}


Appendix 1. High-water marks used to generate flood-inundation maps of selected areas affected by the flood of 0 ctober 2015 in central and coastal South Carolina.-Continued

[Methods for data collection for high-water marks are described in Rydlund and Densmore, 2012. Horizontal coordinate information is referenced to the North American Datum of 1983 (NAD 83). Vertical coordinate information is referenced to the North American Vertical Datum of 1988 (NAVD 88).

Location descriptions and HWM notes may be truncated. Abbreviations: ID, identification; HWM, high-water mark; Un. trib., unnamed tributary. -, no data]

\begin{tabular}{|c|c|c|c|c|c|c|c|}
\hline $\begin{array}{l}\text { Elevation } \\
\text { (feet) }\end{array}$ & Marker type & $\begin{array}{l}\text { Height } \\
\text { above } \\
\text { ground } \\
\text { (feet) }\end{array}$ & High-water mark notes & $\begin{array}{l}\text { HWM } \\
\text { environ- } \\
\text { ment }\end{array}$ & Flag date & Survey date & $\begin{array}{c}\text { Still } \\
\text { water }\end{array}$ \\
\hline 225.8 & Marker & 0.92 & $\begin{array}{l}\text { Seed line located on fence on northeast side of property } \\
\text { next to a gate, marked with sharpie and flag }\end{array}$ & Urban & $10 / 10 / 2015$ & $10 / 13 / 2015$ & Yes \\
\hline 225.6 & Marker & 1.35 & $\begin{array}{l}\text { Seed line located on handicap parking sign post, } \\
\text { marked with sharpie and flagged }\end{array}$ & Urban & $10 / 10 / 2015$ & $10 / 13 / 2015$ & Yes \\
\hline 241.8 & Marker & 0.81 & $\begin{array}{l}\text { Seed line located at windsor shores apartments } \\
\text { building } 2 \text { in the breezeway between } \mathrm{E} \text { and } \mathrm{F}\end{array}$ & Urban & $10 / 10 / 2015$ & $10 / 13 / 2015$ & Yes \\
\hline 225.2 & Nail and HWM tag & 1.50 & $\begin{array}{l}\text { Seed line located on dock southeast of building } 2100 ; \\
\text { HWM measured from dock floor }\end{array}$ & Urban & $10 / 10 / 2015$ & $10 / 13 / 2015$ & Yes \\
\hline 231.8 & $\begin{array}{l}\text { Other (Note in } \\
\text { description box) }\end{array}$ & 6.25 & $\begin{array}{l}\text { HWM marked with concrete anchor and flagging; } \\
\text { Seed line located on Bridge Pier on north end of } \\
\text { bridge }\end{array}$ & Rural & $10 / 10 / 2015$ & $10 / 13 / 2015$ & No \\
\hline 189.3 & Marker & 2.50 & $\begin{array}{l}\text { Second shed on far side of school, net to field on right } \\
\text { side of door frame; HWM marked with marker }\end{array}$ & Urban & $10 / 10 / 2015$ & $10 / 15 / 2015$ & No \\
\hline 202.4 & Marker & 2.20 & $\begin{array}{l}\text { Corner post } 15^{\prime} \text { from guard rail, } 30^{\prime} \text { from stream; } \\
\text { HWM marked with marker and colored flagging }\end{array}$ & Urban & $10 / 10 / 2015$ & $10 / 15 / 2015$ & No \\
\hline 205.4 & Tape & 1.40 & $\begin{array}{l}\text { On right hand side of garage door on frame; HWM } \\
\text { marked with colored flagging and pencil }\end{array}$ & Urban & $10 / 10 / 2015$ & $10 / 15 / 2015$ & No \\
\hline 213.3 & Marker & 4.10 & $\begin{array}{l}\text { Upstream/stream side corner on galvanized hot water } \\
\text { heater encloser; HWM marked with marker and colo }\end{array}$ & Urban & $10 / 10 / 2015$ & $10 / 16 / 2015$ & No \\
\hline 216.1 & Marker & 0.60 & $\begin{array}{l}\text { Brick 3rd course up, behind holly bush; HWM marked } \\
\text { with marker and colored flagging }\end{array}$ & Urban & $10 / 10 / 2015$ & $10 / 16 / 2015$ & No \\
\hline 161.9 & Marker & 4.12 & - & Urban & $10 / 9 / 2015$ & $10 / 12 / 2015$ & No \\
\hline 162.0 & Marker & 3.31 & HWM marked with square & Urban & $10 / 9 / 2015$ & $10 / 12 / 2015$ & Yes \\
\hline 191.5 & Nail & 1.59 & Nail \& flagging & - & $10 / 9 / 2015$ & $10 / 13 / 2015$ & No \\
\hline 148.7 & Marker & 1.30 & SC-RIC-1006-A; black sharpie & Urban & $10 / 8 / 2015$ & $10 / 11 / 2015$ & Yes \\
\hline 148.7 & Marker & 1.49 & SC-RIC-1006-B; sharpie & Urban & $10 / 8 / 2015$ & $10 / 11 / 2015$ & Yes \\
\hline 148.8 & Marker & 3.03 & Sharpie & Urban & $10 / 8 / 2015$ & $10 / 11 / 2015$ & Yes \\
\hline 149.5 & - & 4.10 & - & Urban & $10 / 8 / 2015$ & $10 / 11 / 2015$ & No \\
\hline 149.4 & Nail & 4.15 & SC-RIC-1008-B; also colored flagging & Urban & $10 / 8 / 2015$ & $10 / 11 / 2015$ & No \\
\hline 150.2 & Marker & 1.53 & Sharpie & Urban & $10 / 8 / 2015$ & $10 / 11 / 2015$ & Yes \\
\hline 158.0 & $\begin{array}{l}\text { Other (Note in } \\
\text { description box) }\end{array}$ & 6.28 & $\begin{array}{l}\text { SC-RIC-1010-A; sharpie 'square' on doorstep tape up } \\
\text { to mark }=0.58 \text { ' tape down from doorstep to groun }\end{array}$ & Urban & $10 / 8 / 2015$ & $10 / 11 / 2015$ & No \\
\hline 157.2 & Marker & 1.41 & SC-RIC-1010-B; other - black sharpie & Urban & $10 / 8 / 2015$ & $10 / 11 / 2015$ & No \\
\hline
\end{tabular}


Appendix 1. High-water marks used to generate flood-inundation maps of selected areas affected by the flood of October 2015 in central and coastal South Carolina.-Continued

[Methods for data collection for high-water marks are described in Rydlund and Densmore, 2012. Horizontal coordinate information is referenced to the North American Datum of 1983 (NAD 83). Vertical coordinate information is referenced to the North American Vertical Datum of 1988 (NAVD 88).

Location descriptions and HWM notes may be truncated. Abbreviations: ID, identification; HWM, high-water mark; Un. trib., unnamed tributary. -, no data]

\begin{tabular}{|c|c|c|c|c|c|c|c|}
\hline HWM ID & Waterbody & Site ID & HWM type & $\begin{array}{l}\text { HWM } \\
\text { quality }\end{array}$ & HWM location description & Latitude & Longitude \\
\hline 11507 & Gills Creek & 14797 & $\begin{array}{l}\text { Other (Note in } \\
\text { description box) }\end{array}$ & Fair & $\begin{array}{l}\text { SC-RIC-1010-C; Latter Day Saints Church } \\
\text { @ Jackson Blvd - embankment in front of } \\
\text { churchnear church si }\end{array}$ & 33.99223 & -80.97121 \\
\hline 11509 & Gills Creek & 14797 & Seed line & Excellent & $\begin{array}{l}\text { SC-RIC-1010-E; Business - Chocolate Nirvana } \\
\text { Bakery \& Café @ Jackson Blvd located on } \\
\text { upstream right b }\end{array}$ & 33.99213 & -80.97309 \\
\hline 11510 & Gills Creek & 14798 & Seed line & Excellent & $\begin{array}{l}\text { SC-RIC-1011-A; } 15 \text { Downing Street; Access to } \\
\text { shed from back yard. Shed is in neighbor's } \\
\text { yard (11 Down }\end{array}$ & 33.99392 & -80.96957 \\
\hline 11512 & Gills Creek & 14799 & Seed line & Excellent & $\begin{array}{l}\text { Exc seed line on front door -> survey 'square" on } \\
\text { door sill } 0.42 \text { ' above sharpie 'square' at door ste }\end{array}$ & 33.99508 & -80.96621 \\
\hline 11513 & Gills Creek & 14800 & Seed line & Excellent & $\begin{array}{l}\text { Survey from concrete at garage entrance - bricks } \\
\text { have sharpie mark 'square' on garage floor } \\
\text { (a) mark }\end{array}$ & 33.99896 & -80.96282 \\
\hline 11514 & Gills Creek & 14801 & Seed line & Excellent & $\begin{array}{l}\text { Exc seed line on N side of house next to fence } \\
\& \text { gate. Sharpie mark on fence, } 2 \text { nd board } \\
\text { from house }\end{array}$ & 34.00076 & -80.96178 \\
\hline 11515 & Gills Creek & 14802 & Seed line & Good & $\begin{array}{l}\text { Good seed line on bricks - survey 'square with } \\
\text { x in middle' on curb }\end{array}$ & 34.00261 & -80.96051 \\
\hline 11516 & Gills Creek & 14803 & Seed line & Excellent & $\begin{array}{l}\text { Exc seed line on concrete wall on South side of } \\
\text { property approx 10' from end of driveway }\end{array}$ & 34.0048 & -80.95761 \\
\hline 11517 & Gills Creek & 14804 & Seed line & Excellent & $\begin{array}{l}\text { Exc seed line at shed in backyard. Sharpie mark } \\
\text { on corner closest to house }\end{array}$ & 34.00797 & -80.95554 \\
\hline 11531 & $\begin{array}{l}\text { Little Jackson } \\
\text { Creek }\end{array}$ & 14817 & Seed line & Excellent & Stairwel1/door 228-B/business closet to O'Neil Court & 34.06997 & -80.95406 \\
\hline 11532 & $\begin{array}{l}\text { Little Jackson } \\
\text { Creek }\end{array}$ & 14818 & Debris & Poor & Poor trash line on shrubs/Dumpster housing Rt wall & 34.07052 & -80.95426 \\
\hline 11533 & $\begin{array}{l}\text { Little Jackson } \\
\quad \text { Creek }\end{array}$ & 14819 & Seed line & Good & $\begin{array}{l}\text { Deer Park Apartments/top 4th brick, Apt D3 } \\
\text { corner next to gutter facing creek }\end{array}$ & 34.07306 & -80.95409 \\
\hline 12010 & Pen Branch & 15055 & Seed line & Fair & $\begin{array}{l}\text { SC-RIC-737-B; On opposite side of Falcon Rd } \\
\text { than AC Flora baseball field }\end{array}$ & 34.01434 & -80.98371 \\
\hline 12030 & $\begin{array}{l}\text { Little Jackson } \\
\quad \text { Creek }\end{array}$ & 14815 & Seed line & Good & SC-RIC-947-B; Right D/S side of bridge & 34.06455 & -80.95324 \\
\hline 12050 & Wildcat Creek & 15328 & Seed line & Good & Near building 2609 Ft Jackson & 33.99506 & -80.94064 \\
\hline 11730 & Jackson Creek & 15008 & Seed line & Fair & $\begin{array}{l}\text { Intersection of Spring Lake Rd \& Shorebrook } \\
\text { Rd, on bank of Spring Lake. Large pine, } \\
\text { inline with powe }\end{array}$ & 34.03721 & -80.95733 \\
\hline 11731 & Jackson Creek & 15009 & Seed line & Excellent & $\begin{array}{l}\text { Sharpie mark on right frame of crawl space door } \\
\text { on right side of house at } 4125 \text { Shorebrook Dr }\end{array}$ & 34.03803 & -80.95741 \\
\hline 11733 & Jackson Creek & 15011 & Seed line & Good & $\begin{array}{l}\text { Rockbridge Club @ pool house. Front left of } \\
\text { wooden storage building. Left of pool house } \\
\text { down in grav }\end{array}$ & 34.04683 & -80.9583 \\
\hline
\end{tabular}


Appendix 1. High-water marks used to generate flood-inundation maps of selected areas affected by the flood of October 2015 in central and coastal South Carolina.-Continued

[Methods for data collection for high-water marks are described in Rydlund and Densmore, 2012. Horizontal coordinate information is referenced to the North American Datum of 1983 (NAD 83). Vertical coordinate information is referenced to the North American Vertical Datum of 1988 (NAVD 88).

Location descriptions and HWM notes may be truncated. Abbreviations: ID, identification; HWM, high-water mark; Un. trib., unnamed tributary. - , no data]

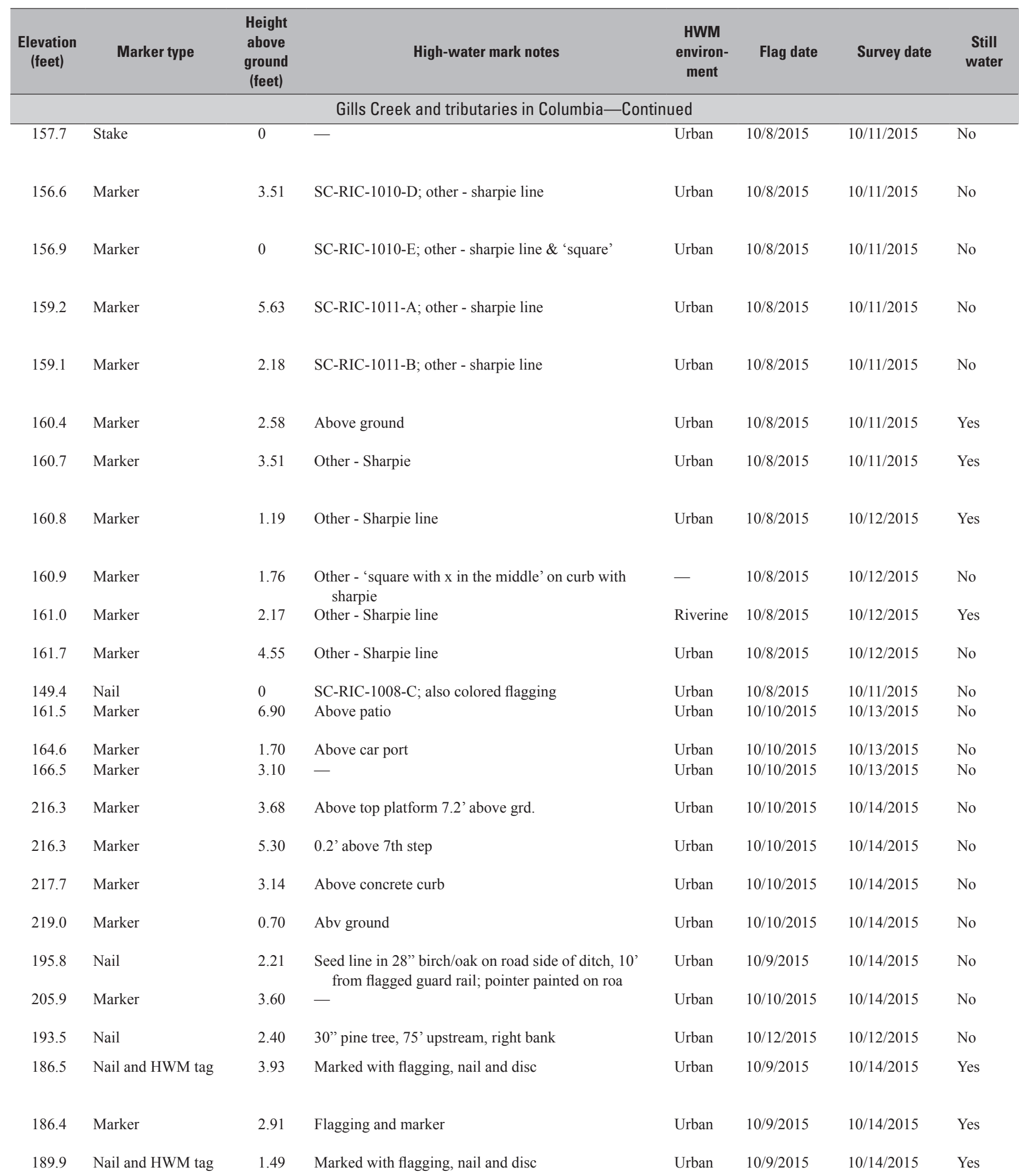


Appendix 1. High-water marks used to generate flood-inundation maps of selected areas affected by the flood of October 2015 in central and coastal South Carolina.-Continued

[Methods for data collection for high-water marks are described in Rydlund and Densmore, 2012. Horizontal coordinate information is referenced to the North American Datum of 1983 (NAD 83). Vertical coordinate information is referenced to the North American Vertical Datum of 1988 (NAVD 88).

Location descriptions and HWM notes may be truncated. Abbreviations: ID, identification; HWM, high-water mark; Un. trib., unnamed tributary. -, no data]

\begin{tabular}{|c|c|c|c|c|c|c|c|}
\hline HWM ID & Waterbody & Site ID & HWM type & $\begin{array}{l}\text { HWM } \\
\text { quality }\end{array}$ & HWM location description & Latitude & Longitude \\
\hline 11734 & Jackson Creek & 15012 & Seed line & Fair & $\begin{array}{l}208 \text { Arcadia Lakes Dr E at bridge crossing. In } \\
\text { pine on upstream right bank of Carys Lake } \\
\text { in line with }\end{array}$ & 34.04877 & -80.95844 \\
\hline 11736 & Jackson Creek & 15014 & Seed line & Good & $\begin{array}{l}6748 \text { Cary Lane, Sharpie mark on entry door } \\
\text { left of garage on side of house }\end{array}$ & 34.05536 & -80.95708 \\
\hline 11737 & Jackson Creek & 15015 & Seed line & $\begin{array}{l}\text { Unknown/ } \\
\text { historical }\end{array}$ & 6808 Pine Tree Cir; on mailbox brick structure. & 34.05707 & -80.95541 \\
\hline 11738 & Jackson Creek & 15016 & Seed line & Fair & $\begin{array}{l}6800 \text { Pine Tree Cir; on privacy fence between } \\
\text { House and N Trenholm Rd }\end{array}$ & 34.05641 & -80.95683 \\
\hline 11741 & $\begin{array}{l}\text { Jackson Creek } \\
\text { tributary }\end{array}$ & 15019 & Seed line & Good & $\begin{array}{l}35 \text { Lakecrest Dr. USGS monitoring well on } \\
\text { left edge of driveway (green cover flush to } \\
\text { ground). Sharpi }\end{array}$ & 34.05178 & -80.96136 \\
\hline 11742 & $\begin{array}{c}\text { Jackson Creek } \\
\text { tributary }\end{array}$ & 15020 & Seed line & Good & $\begin{array}{l}2 \text { Lakecrest Dr. House on corner of Lakecrest } \\
\text { \& Trenholm Rd. In Pine near waters edge } \\
\text { behind house ne }\end{array}$ & 34.05083 & -80.95992 \\
\hline 11743 & Jackson Creek & 15021 & Seed line & Good & $\begin{array}{l}6185 \text { Eastshore Rd at intersection with } \\
\text { Shorebrook. On Right side of right garage } \\
\text { at front of house }\end{array}$ & 34.03698 & -80.9547 \\
\hline 11744 & Jackson Creek & 15022 & Seed line & Good & 6205 Eastshore Rd, on brick mailbox & 34.03921 & -80.95489 \\
\hline 11770 & Pen Branch & 15048 & Seed line & Good & $\begin{array}{l}\text { Facing house, taked fence in on right to back of } \\
\text { lot, exit backyard thru gate }\end{array}$ & 34.01263 & -80.98022 \\
\hline 11775 & Pen Branch & 15053 & Seed line & Good & Off of Beltline Blvd & 34.01246 & -80.98359 \\
\hline 11776 & Pen Branch & 15054 & Seed line & Good & Sato Sushi Restaurant & 34.01322 & -80.9844 \\
\hline 11778 & Pen Branch & 15056 & Seed line & Excellent & Behind residence & 34.01233 & -80.98606 \\
\hline 11779 & Pen Branch & 15057 & Seed line & Good & $\begin{array}{l}\text { In very back of property; need to get permission } \\
\text { from landowner }\end{array}$ & 34.01247 & -80.98656 \\
\hline 11780 & Pen Branch & 15058 & Seed line & Good & In front yard & 34.01450 & -80.98892 \\
\hline 11781 & Pen Branch & 15059 & Seed line & Good & $\begin{array}{l}\text { Backside underneath in parking area near } \\
\text { Verizon Wireless employee parking }\end{array}$ & 34.01540 & -80.98965 \\
\hline 11782 & Pen Branch & 15060 & Seed line & Good & Facing house HWM is to the left on front corner & 34.01867 & -80.99522 \\
\hline 11783 & Pen Branch & 15061 & Seed line & Good & Golden Chick & 34.01484 & -80.98745 \\
\hline 11784 & Pen Branch & 15062 & Seed line & Good & $\begin{array}{l}\text { Firestone tire behind building on left back } \\
\text { corner area }\end{array}$ & 34.01413 & -80.98604 \\
\hline 11785 & Pen Branch & 15063 & Seed line & Good & - & 34.01144 & -80.97730 \\
\hline
\end{tabular}


Appendix 1. High-water marks used to generate flood-inundation maps of selected areas affected by the flood of 0 ctober 2015 in central and coastal South Carolina.-Continued

[Methods for data collection for high-water marks are described in Rydlund and Densmore, 2012. Horizontal coordinate information is referenced to the North American Datum of 1983 (NAD 83). Vertical coordinate information is referenced to the North American Vertical Datum of 1988 (NAVD 88).

Location descriptions and HWM notes may be truncated. Abbreviations: ID, identification; HWM, high-water mark; Un. trib., unnamed tributary. -, no data]

\begin{tabular}{|c|c|c|c|c|c|c|c|}
\hline $\begin{array}{c}\text { Elevation } \\
\text { (feet) }\end{array}$ & Marker type & $\begin{array}{l}\text { Height } \\
\text { above } \\
\text { ground } \\
\text { (feet) }\end{array}$ & High-water mark notes & $\begin{array}{c}\text { HWM } \\
\text { environ- } \\
\text { ment }\end{array}$ & Flag date & Survey date & $\begin{array}{c}\text { Still } \\
\text { water }\end{array}$ \\
\hline 199.4 & Nail and HWM tag & 4.02 & Marked with flagging, nail and disc & Urban & $10 / 9 / 2015$ & $10 / 13 / 2015$ & Yes \\
\hline 199.8 & Marker & 2.12 & Flagging and marker & Urban & $10 / 9 / 2015$ & $10 / 13 / 2015$ & Yes \\
\hline 199.8 & Marker & 2.30 & Flagging and marker & Urban & $10 / 9 / 2015$ & $10 / 13 / 2015$ & Yes \\
\hline 199.6 & Nail and HWM tag & 3.87 & Marked with flagging, nail and disc & Urban & $10 / 9 / 2015$ & $10 / 13 / 2015$ & No \\
\hline 199.8 & Marker & 3.28 & Flagging and marker & Urban & $10 / 9 / 2015$ & $10 / 13 / 2015$ & Yes \\
\hline 198.2 & Nail and HWM tag & 2.20 & Marked with flagging, nail and disc & Urban & $10 / 9 / 2015$ & $10 / 13 / 2015$ & No \\
\hline 186.1 & Marker & 1.35 & Flagging and marker & Urban & $10 / 9 / 2015$ & $10 / 14 / 2015$ & No \\
\hline 186.1 & Marker & 2.54 & Flagging and marker & Urban & $10 / 9 / 2015$ & $10 / 14 / 2015$ & No \\
\hline 186.7 & Nail & 3.26 & $\begin{array}{l}\text { Seed line on } 28^{\prime \prime} \text { hardwood, just below and outside } \\
\text { of fenceabout } 25 \text { '; tree is located in the center o }\end{array}$ & Urban & 10/9/2015 & $10 / 14 / 2015$ & No \\
\hline 187.5 & Nail & 1.98 & Seed line on inside of door to crawl space of house & Urban & $10 / 9 / 2015$ & $10 / 14 / 2015$ & Yes \\
\hline 187.6 & Nail & 2.55 & Seed line on inside of fence approx 5 , from gate & Urban & $10 / 9 / 2015$ & $10 / 14 / 2015$ & No \\
\hline 187.7 & Nail & 3.82 & $\begin{array}{l}\text { Seed line on double tree in front yard of residence, } \\
200^{\prime} \text { from Pen Branch, 20' from road }\end{array}$ & Urban & $10 / 9 / 2015$ & $10 / 14 / 2015$ & No \\
\hline 196.4 & Tape & 3.09 & $\begin{array}{l}\text { Seed line on shoreward side of Cond near fireplace } \\
\text { foundation }\end{array}$ & Urban & $10 / 9 / 2015$ & $10 / 14 / 2015$ & Yes \\
\hline 196.5 & Marker & 2.53 & $\begin{array}{l}\text { Seed line on outside streamward wall, mark is on } \\
\text { AC unit which is } 25^{\prime} \text { from back of building }\end{array}$ & Urban & $10 / 9 / 2015$ & $10 / 14 / 2015$ & No \\
\hline 196.6 & Nail & 4.45 & $\begin{array}{l}\text { Seed line inside of shed, nail set in back molding of } \\
\text { entry door. Shed located behind residence }\end{array}$ & Urban & $10 / 9 / 2015$ & $10 / 14 / 2015$ & Yes \\
\hline 196.8 & Nail & 1.83 & Seed line on dog house in pen at very bak of residence & Urban & $10 / 9 / 2015$ & $10 / 14 / 2015$ & Yes \\
\hline 198.1 & Nail & 2.23 & $\begin{array}{l}\text { Seed line on } 24 " \text { dia Pine on left side of driveway } \\
\text { going into residence }\end{array}$ & Urban & $10 / 9 / 2015$ & $10 / 14 / 2015$ & No \\
\hline 198.4 & Marker & 1.19 & Seed line/dirtline underneath mall on support pier & Urban & $10 / 9 / 2015$ & $10 / 14 / 2015$ & Yes \\
\hline 213.6 & Nail & 3.15 & $\begin{array}{l}\text { Seed line on side of house, behind hedges close to } \\
\text { font of house }\end{array}$ & Urban & $10 / 9 / 2015$ & $10 / 14 / 2015$ & No \\
\hline 197.1 & Marker & 1.72 & $\begin{array}{l}\text { Seed line on retaining wall on the right side of building; } \\
\sim 60 \text { ' from Pen Branch which is in back of } \mathrm{p}\end{array}$ & Urban & $10 / 9 / 2015$ & $10 / 14 / 2015$ & Yes \\
\hline 196.7 & Marker & 1.24 & $\begin{array}{l}\text { Seed line on back of building, mark is } \sim 9 \text { ' from back } \\
\text { left corner } \sim 6^{\prime} \text { from gutter }\end{array}$ & Urban & $10 / 9 / 2015$ & $10 / 14 / 2015$ & Yes \\
\hline 179.9 & Nail & 1.25 & $\begin{array}{l}\text { Seed line inside of garden shed at left back near } \\
\text { corner of lot }\end{array}$ & Urban & $10 / 9 / 2015$ & $10 / 15 / 2015$ & Yes \\
\hline
\end{tabular}


Appendix 1. High-water marks used to generate flood-inundation maps of selected areas affected by the flood of October 2015 in central and coastal South Carolina.-Continued

[Methods for data collection for high-water marks are described in Rydlund and Densmore, 2012. Horizontal coordinate information is referenced to the North American Datum of 1983 (NAD 83). Vertical coordinate information is referenced to the North American Vertical Datum of 1988 (NAVD 88).

Location descriptions and HWM notes may be truncated. Abbreviations: ID, identification; HWM, high-water mark; Un. trib., unnamed tributary. -, no data]

\begin{tabular}{|c|c|c|c|c|c|c|c|}
\hline HWM ID & Waterbody & Site ID & HWM type & $\begin{array}{l}\text { HWM } \\
\text { quality }\end{array}$ & HWM location description & Latitude & Longitude \\
\hline 11786 & Pen Branch & 15064 & Seed line & Good & - & 34.00920 & -80.97424 \\
\hline 11787 & Pen Branch & 15065 & Seed line & Good & - & 34.00878 & -80.97256 \\
\hline 11950 & Gills $\mathrm{Cr}$ & 15288 & Seed line & Excellent & Location of dam failure & 34.03575 & -80.95172 \\
\hline 11959 & Carys Lake & 15297 & Seed line & Good & - & 34.05371 & -80.95323 \\
\hline 11960 & Carys Lake & 15298 & Seed line & Good & - & 34.04271 & -80.95549 \\
\hline \multicolumn{8}{|c|}{ Kinley Creek near Columbia } \\
\hline 11273 & Kinley Creek & 14450 & Seed line & Good & $\begin{array}{l}\text { SC-LEX-616-B; Downstream side left bank } \\
\text { abutment }\end{array}$ & 34.04658 & -81.14925 \\
\hline 11274 & Kinley Creek & 14451 & Seed line & Good & Front porch of brick home, right banister upright & 34.05465 & -81.15297 \\
\hline 11275 & Kinley Creek & 14452 & Seed line & Good & Left side of right garage door face & 34.05754 & -81.15308 \\
\hline 11276 & Kinley Creek & 14453 & Seed line & Good & $\begin{array}{l}\text { Located on power transformer box behind } \\
\text { residence }\end{array}$ & 34.0663 & -81.1591 \\
\hline 11277 & Kinley Creek & 14454 & Seed line & Good & Located besides gutter at garage on front of house & 34.06112 & -81.15565 \\
\hline 11278 & Kinley Creek & 14455 & Seed line & Good & $\begin{array}{l}\text { SC-LEX-621A; Found on SW corner (of } \\
\text { residence) on gutter }\end{array}$ & 34.0719 & -81.16311 \\
\hline 11279 & Kinley Creek & 14455 & Seed line & Good & $\begin{array}{l}\text { SC-LEX-621B; Located at back of residence } \\
\text { on garage personal door }\end{array}$ & 34.07159 & -81.16277 \\
\hline 11280 & Kinley Creek & 14455 & Seed line & Good & $\begin{array}{l}\text { SC-LEX-621C; Located at side of residence } \\
\text { between } 2 \mathrm{~A} / \mathrm{C} \text { units }\end{array}$ & 34.072 & -81.16277 \\
\hline \multicolumn{8}{|c|}{ Mill Creek and tributaries near Columbia } \\
\hline 11890 & Mill Creek & 15228 & Seed line & Fair & SC-RIC-1701A; 9" hardwood tree in woods behind & 33.96275 & -80.91052 \\
\hline 11891 & Mill Creek & 15228 & Seed line & Poor & $\begin{array}{l}\text { SC-RIC-1701B; } 18 \text { " hardwood next to SC-RIC- } \\
\quad 1701 \mathrm{~F}\end{array}$ & 33.96275 & -80.91052 \\
\hline 11892 & Mill Creek & 15228 & Seed line & Poor & $\begin{array}{l}\text { SC-RIC-1701C; } 6 " \text { tree } \sim 35 \text { ' ds of } 1701 \mathrm{~A} \text { and } \\
\text { 1701B. }\end{array}$ & 33.96275 & -80.91052 \\
\hline 11893 & Mill Creek & 15229 & Seed line & Poor & $\begin{array}{l}\text { SC-RIC-1702B; 6' pine tree } \sim 75 \text { from Caugh- } \\
\text { man Rd on DS right bank, DS from dam }\end{array}$ & 33.96427 & -80.91073 \\
\hline 11894 & Mill Creek & 15229 & Seed line & Poor & $\begin{array}{l}\text { SC-RIC-1702A; DS rt side of stream just ds of } \\
\text { dam on Caughman Rd. Coughman Road was } \\
\text { overtopped. 6" h }\end{array}$ & 33.96416 & -80.91070 \\
\hline 11895 & Mill Creek & 15229 & Seed line & Poor & $\begin{array}{l}\text { SC-RIC-1702C; DS rt of Coughman Rd. 18" pine } \\
\text { tree } 65 \text { feet from rd about } 10 \mathrm{ft} \text { ds of } 1702 \mathrm{~B}\end{array}$ & 33.96414 & -80.91086 \\
\hline 11896 & Mill Creek & 15230 & Seed line & Good & $\begin{array}{l}\text { SC-RIC-1703A; Caughman Rd Dam from } \\
\text { Mill Creek below Sun View Lake. }\end{array}$ & 33.96485 & -80.91101 \\
\hline 11897 & Mill Creek & 15230 & Seed line & Good & $\begin{array}{l}\text { SC-RIC-1703B; Caughman Rd Dam from } \\
\text { Mill Creek. Pine tree (12") } \sim 35 \mathrm{ft} \text { from } \\
\text { Caughman Rd on US right }\end{array}$ & 33.96485 & -80.91101 \\
\hline
\end{tabular}


Appendix 1. High-water marks used to generate flood-inundation maps of selected areas affected by the flood of 0 ctober 2015 in central and coastal South Carolina._- Continued

[Methods for data collection for high-water marks are described in Rydlund and Densmore, 2012. Horizontal coordinate information is referenced to the North American Datum of 1983 (NAD 83). Vertical coordinate information is referenced to the North American Vertical Datum of 1988 (NAVD 88).

Location descriptions and HWM notes may be truncated. Abbreviations: ID, identification; HWM, high-water mark; Un. trib., unnamed tributary. 一, no data]

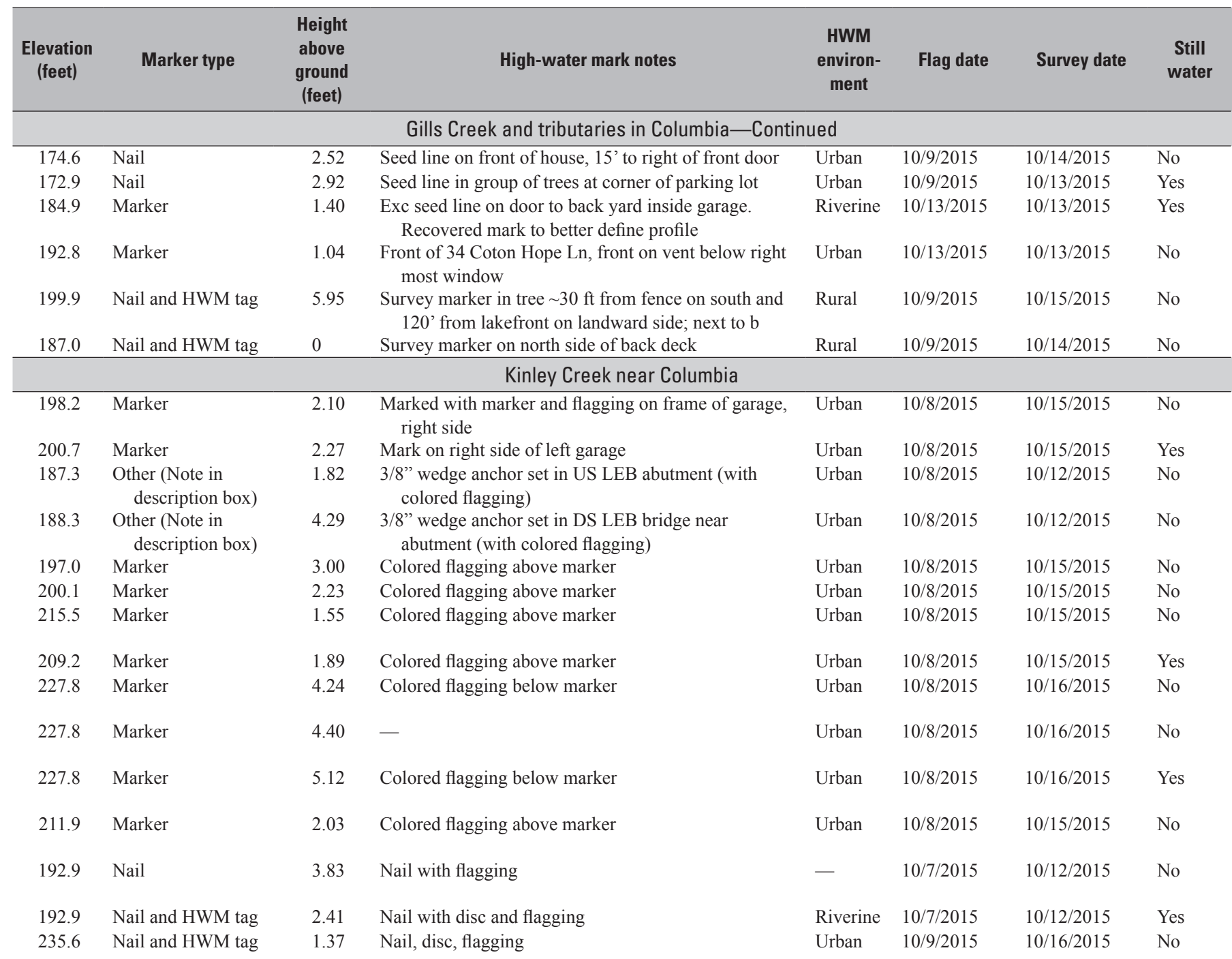

\begin{tabular}{|c|c|c|c|c|c|c|c|}
\hline \multicolumn{8}{|c|}{ Mill Creek and tributaries near Columbia } \\
\hline 203.5 & Nail & 2.30 & Flagging and nail & Rural & $10 / 9 / 2015$ & $10 / 14 / 2015$ & No \\
\hline 203.7 & Nail & 1.83 & Flagging and nail & Rural & $10 / 9 / 2015$ & $10 / 14 / 2015$ & No \\
\hline 203.5 & Nail & 2.67 & Flagging and nail & Rural & $10 / 9 / 2015$ & $10 / 14 / 2015$ & No \\
\hline 210.6 & Nail & 2.25 & Flagging and nail & Rural & $10 / 9 / 2015$ & $10 / 14 / 2015$ & No \\
\hline 210.1 & Nail & 1.42 & $\begin{array}{l}\text { Flagging and nail; poor seed line with some } \\
\text { splash a little higher }\end{array}$ & Rural & $10 / 9 / 2015$ & $10 / 14 / 2015$ & No \\
\hline 210.4 & Nail & 1.42 & Flagging and nail & Riverine & $10 / 9 / 2015$ & $10 / 14 / 2015$ & No \\
\hline 213.2 & Nail & 2.17 & Flagging and nail & Rural & $10 / 9 / 2015$ & $10 / 14 / 2015$ & No \\
\hline 213.2 & Nail & 2.33 & Flagging and nail & Rural & $10 / 9 / 2015$ & $10 / 14 / 2015$ & No \\
\hline
\end{tabular}


Appendix 1. High-water marks used to generate flood-inundation maps of selected areas affected by the flood of 0 ctober 2015 in central and coastal South Carolina.-Continued

[Methods for data collection for high-water marks are described in Rydlund and Densmore, 2012. Horizontal coordinate information is referenced to the North American Datum of 1983 (NAD 83). Vertical coordinate information is referenced to the North American Vertical Datum of 1988 (NAVD 88).

Location descriptions and HWM notes may be truncated. Abbreviations: ID, identification; HWM, high-water mark; Un. trib., unnamed tributary. -, no data]

\begin{tabular}{|c|c|c|c|c|c|c|c|}
\hline HWM ID & Waterbody & Site ID & HWM type & $\begin{array}{l}\text { HWM } \\
\text { quality }\end{array}$ & HWM location description & Latitude & Longitude \\
\hline 11898 & Mill Creek & 15231 & Mud & Poor & $\begin{array}{l}\text { SC-RIC-1704A; Caughman Rd Dam to Mill } \\
\text { Creek DS of Sun View Lake. 3" hardwood } \\
\sim 100 \mathrm{ft} \text { from Caughman R }\end{array}$ & 33.96344 & -80.91006 \\
\hline 11900 & Mill Creek & 15232 & Seed line & Excellent & $\begin{array}{l}\text { House at } 7921 \text { Teague Rd; call before } \\
\text { surveying, dangerous dogs. On carport } \\
\text { behind house, near lake o }\end{array}$ & 33.96532 & -80.91014 \\
\hline 11901 & Mill Creek Trib & 15233 & Seed line & Excellent & $\begin{array}{l}\text { Cardington Rd, behind house. On an above- } \\
\text { ground pool in backyard. On front of pool } \\
\text { on a ribpost (4th }\end{array}$ & 33.97491 & -80.90742 \\
\hline 11903 & Mill Creek Trib & 15235 & Seed line & Excellent & $\begin{array}{l}\text { Dam between Ulmers Pond and Griffin at } \\
1 \text { Trotwood Rd. Mark on gutter spout on } \\
\text { front of house, on Ra }\end{array}$ & 33.96926 & -80.89269 \\
\hline \multicolumn{8}{|c|}{ Rawls Creek near Columbia } \\
\hline${ }^{2} 11233$ & Rawls Creek & 14411 & Seed line & Good & $\begin{array}{l}\text { Cross foot bridge and Green info sign under } \\
\text { power lines on end of foot bridge }\end{array}$ & 34.05177 & -81.1861 \\
\hline 11234 & Rawls Creek & 14412 & Seed line & Good & - & 34.05653 & -81.18764 \\
\hline 11235 & Koon Branch & 14413 & Seed line & Good & Along privacy fence on left side yard & 34.05783 & -81.18619 \\
\hline 11236 & Rawls Creek & 14414 & Seed line & Good & - & 34.05845 & -81.20003 \\
\hline 11284 & Rawls Creek & 14459 & Seed line & Good & Located on left garage door molding & 34.05798 & -81.19464 \\
\hline 11285 & Rawls Creek & 14460 & Seed line & Good & Located on gutter on southwest corner of home & 34.05751 & -81.1959 \\
\hline 11286 & Rawls Creek & 14461 & Seed line & Good & Located on northwest corner of home & 34.06027 & -81.19793 \\
\hline 11287 & Rawls Creek & 14462 & Seed line & Good & Located on left garage door & 34.06132 & -81.19857 \\
\hline 11288 & Rawls Creek & 14463 & Seed line & Good & $\begin{array}{l}\text { Located at back of residence at crawl space } \\
\text { entrance beside } \mathrm{A} / \mathrm{C} \text { unit }\end{array}$ & 34.06424 & -81.20083 \\
\hline 11459 & Rawls Creek & 14757 & Seed line & Good & $\begin{array}{l}121 \text { Old Arms Ct, Seed line located on inside of shed } \\
\text { door transferred to outside with sharpie and fla }\end{array}$ & 34.06801 & -81.20437 \\
\hline 11460 & Rawls Creek & 14758 & Seed line & Fair & $\begin{array}{l}\text { Beverly Brandes Community Park on } \\
\text { Coldstream Dr; seedling located on a tree } \\
\text { east of slides marked wi }\end{array}$ & 34.06826 & -81.20803 \\
\hline 11461 & Rawls Creek & 14759 & Seed line & Good & $\begin{array}{l}\text { SC-LEX-632A; Residence located on } \\
112 \text { Baden Ct; Seed line located on } \\
\text { southwest corner of home. }\end{array}$ & 34.06879 & -81.20501 \\
\hline 11462 & Rawls Creek & 14759 & Seed line & Good & $\begin{array}{l}\text { SC-LEX-632B; Residence located at } \\
107 \text { Baden Ct; seed line located on garage } \\
\text { door molding on left. }\end{array}$ & 34.06872 & -81.20511 \\
\hline 11463 & Rawls Creek & 14760 & Seed line & Good & $\begin{array}{l}180 \text { Cannon Dale Rd; seed line located on } \\
\text { garage door molding. }\end{array}$ & 34.06755 & -81.20507 \\
\hline
\end{tabular}


Appendix 1. High-water marks used to generate flood-inundation maps of selected areas affected by the flood of 0 ctober 2015 in central and coastal South Carolina.-Continued

[Methods for data collection for high-water marks are described in Rydlund and Densmore, 2012. Horizontal coordinate information is referenced to the North American Datum of 1983 (NAD 83). Vertical coordinate information is referenced to the North American Vertical Datum of 1988 (NAVD 88).

Location descriptions and HWM notes may be truncated. Abbreviations: ID, identification; HWM, high-water mark; Un. trib., unnamed tributary. - , no data]

\begin{tabular}{|c|c|c|c|c|c|c|c|}
\hline $\begin{array}{c}\text { Elevation } \\
\text { (feet) }\end{array}$ & Marker type & $\begin{array}{l}\text { Height } \\
\text { above } \\
\text { ground } \\
\text { (feet) }\end{array}$ & High-water mark notes & $\begin{array}{c}\text { HWM } \\
\text { environ- } \\
\text { ment }\end{array}$ & Flag date & Survey date & $\begin{array}{c}\text { Still } \\
\text { water }\end{array}$ \\
\hline 205.4 & Nail & 4.50 & Flagging and nail & Rural & $10 / 9 / 2015$ & $10 / 14 / 2015$ & No \\
\hline 213.4 & Marker & 2.75 & - & Rural & $10 / 9 / 2015$ & $10 / 13 / 2015$ & No \\
\hline 239.1 & Marker & 1.33 & - & Urban & $10 / 9 / 2015$ & $10 / 14 / 2015$ & No \\
\hline 243.1 & Marker & 1.50 & - & Urban & $10 / 9 / 2015$ & $10 / 14 / 2015$ & No \\
\hline
\end{tabular}

\section{Rawls Creek near Columbia}

\begin{tabular}{|c|c|c|c|c|c|c|c|}
\hline 193.0 & Marker & 6.14 & $\begin{array}{l}\text { Sharpie line on right post of green info board near end } \\
\text { of foot bridge downstream of Rawls Crk Bridg }\end{array}$ & Urban & $10 / 8 / 2015$ & $10 / 15 / 2015$ & No \\
\hline 201.4 & Marker & 6.88 & $\begin{array}{l}\text { Sharpie mark on bath house near entrance left of } \\
\text { Awning left side of entrance }\end{array}$ & Urban & $10 / 8 / 2015$ & $10 / 15 / 2015$ & Yes \\
\hline 196.9 & Nail and HWM tag & 1.10 & $\begin{array}{l}\text { Nail and disc in privacy fence along the left side yard } \\
\text { at } 2033 \text { Cedarbrook dr }\end{array}$ & Urban & $10 / 8 / 2015$ & $10 / 15 / 2015$ & Yes \\
\hline 206.7 & Nail and HWM tag & 1.35 & $\begin{array}{l}\text { Nail and disc on shed in rear of house just left of } \\
\text { black door }\end{array}$ & - & $10 / 8 / 2015$ & $10 / 15 / 2015$ & No \\
\hline 206.6 & Nail and HWM tag & 2.32 & Nail with disc on wooden shed in backyard left of house & Urban & $10 / 8 / 2015$ & $10 / 15 / 2015$ & No \\
\hline 206.5 & Marker & 4.26 & Marker and flagging & Urban & $10 / 8 / 2015$ & $10 / 15 / 2015$ & No \\
\hline 206.2 & Marker & 2.93 & Sharpie mark on right corner of house near palm tree & Urban & $10 / 8 / 2015$ & $10 / 15 / 2015$ & Yes \\
\hline 206.1 & Marker & 2.79 & $\begin{array}{l}\text { Sharpie line of left side of } 104 \text { Wilton Hill Rd left of } \\
\text { garage; HWM type not noted on field form }\end{array}$ & Urban & $10 / 8 / 2015$ & $10 / 15 / 2015$ & Yes \\
\hline 205.7 & Marker & 3.63 & Colored flagging below marker & Urban & $10 / 8 / 2015$ & $10 / 15 / 2015$ & No \\
\hline 206.0 & Marker & 1.46 & Colored flagging above marker & Urban & $10 / 8 / 2015$ & $10 / 15 / 2015$ & Yes \\
\hline 206.1 & Marker & 0.62 & Colored flagging above marker & Urban & $10 / 8 / 2015$ & $10 / 15 / 2015$ & Yes \\
\hline 206.1 & Marker & 5.29 & Colored flagging below marker & Urban & $10 / 8 / 2015$ & $10 / 15 / 2015$ & No \\
\hline 206.9 & Marker & 5.08 & Colored flagging above marker & Urban & $10 / 8 / 2015$ & $10 / 15 / 2015$ & No \\
\hline 207.6 & Marker & 3.37 & Colored flagging above marker & Urban & $10 / 8 / 2015$ & $10 / 15 / 2015$ & No \\
\hline 214.3 & Marker & 2.12 & $\begin{array}{l}\text { Inside mark transferred outside, colored flagging } \\
\text { below marker }\end{array}$ & Urban & $10 / 8 / 2015$ & $10 / 15 / 2015$ & No \\
\hline 227.2 & Marker & 2.67 & Flagging \& marker & Urban & $10 / 9 / 2015$ & $10 / 14 / 2015$ & Yes \\
\hline 236.2 & Nail and HWM tag & 3.20 & Nail, disc, flagging & Urban & $10 / 9 / 2015$ & $10 / 14 / 2015$ & No \\
\hline 229.0 & Marker & 2.26 & Marked with Sharpie and flagged & Urban & $10 / 9 / 2015$ & $10 / 14 / 2015$ & No \\
\hline 229.0 & Marker & 1.56 & Flagging \& marker & Urban & $10 / 9 / 2015$ & $10 / 14 / 2015$ & No \\
\hline 227.2 & Marker & 3.20 & Flagging \& marker & Urban & $10 / 9 / 2015$ & $10 / 14 / 2015$ & No \\
\hline
\end{tabular}


Appendix 1. High-water marks used to generate flood-inundation maps of selected areas affected by the flood of October 2015 in central and coastal South Carolina.-Continued

[Methods for data collection for high-water marks are described in Rydlund and Densmore, 2012. Horizontal coordinate information is referenced to the North American Datum of 1983 (NAD 83). Vertical coordinate information is referenced to the North American Vertical Datum of 1988 (NAVD 88).

Location descriptions and HWM notes may be truncated. Abbreviations: ID, identification; HWM, high-water mark; Un. trib., unnamed tributary. -, no data]

\begin{tabular}{|c|c|c|c|c|c|c|c|}
\hline HWM ID & Waterbody & Site ID & HWM type & $\begin{array}{l}\text { HWM } \\
\text { quality }\end{array}$ & HWM location description & Latitude & Longitude \\
\hline 11464 & Rawls Creek & 14761 & Seed line & Good & $\begin{array}{l}138 \text { Cannon Dale Rd; seed line located on } \\
\text { a/c unit behind residence. }\end{array}$ & 34.06527 & -81.20317 \\
\hline 11465 & Rawls Creek & 14762 & Seed line & Good & $\begin{array}{l}104 \text { Ashridge Ct; seed line located on utility } \\
\text { room }\end{array}$ & 34.06257 & -81.19983 \\
\hline 11953 & Rawls Creek & 15291 & Seed line & Good & $\begin{array}{l}118 \text { Cannon Dale Rd. Survey marker nailed in } \\
\text { house on back, north side corner }\end{array}$ & 34.06435 & -81.2026 \\
\hline 11954 & Rawls Creek & 15292 & Seed line & Good & $\begin{array}{l}259 \text { Danby Ct, back of house between chimney } \\
\text { and window }\end{array}$ & 34.06069 & -81.19921 \\
\hline 11955 & Rawls Creek & 15293 & Seed line & Good & $\begin{array}{l}273 \text { Danby Ct, survey marker on north side of } \\
\text { black shed }\end{array}$ & 34.05979 & -81.19879 \\
\hline 11145 & Rocky Branch & 14360 & Seed line & Fair & $\begin{array}{l}\text { SC-RIC-712; Just above culvert crossing } \\
\text { Sumter St on above Mech Engineering Bldg }\end{array}$ & 33.99096 & -81.02686 \\
\hline${ }^{1} 11146$ & Rocky Branch & 14361 & Seed line & Good & SC-RIC-713; Near Heyward St; & 33.98365 & -81.03147 \\
\hline 11147 & Rocky Branch & 14362 & Seed line & Fair & $\begin{array}{l}\text { SC-RIC-750; Underneath train trestle crossing } \\
\text { on support I-beam }\end{array}$ & 33.99104 & -81.02715 \\
\hline 11148 & Rocky Branch & 14363 & Debris & Poor & SC-RIC-751; Catawba Street at bridge crossing & 33.98964 & -81.02731 \\
\hline 11149 & Rocky Branch & 14364 & Debris & Excellent & $\begin{array}{l}\text { SC-RIC-752; Located underneat train trestle } \\
\text { that crosses Whaley St nrs Assembly St, } \\
\text { Located on west }\end{array}$ & 33.98755 & -81.02889 \\
\hline 11150 & Rocky Branch & 14365 & Debris & Excellent & $\begin{array}{l}\text { SC-RIC-753; Located at the back of house at } \\
109 \text { S Parker St }\end{array}$ & 33.9836 & -81.03423 \\
\hline 11131 & Rocky Branch & 14348 & Seed line & Good & $\begin{array}{l}\text { SC-RIC-701B; Perm. Marker on brick memorial } \\
\text { wall below Second Calvary Baptist Church. } \\
\text { Plaque wall is }\end{array}$ & 34.0009 & -81.01454 \\
\hline 11132 & Rocky Branch & 14348 & Seed line & Good & $\begin{array}{l}\text { SC-RIC-701C; on streamside or southside of } \\
\text { fountain wall in RD floodplain }\end{array}$ & 34.00084 & -81.01468 \\
\hline 11133 & Rocky Branch & 14348 & Seed line & Good & $\begin{array}{l}\text { SC-RIC-701D; large 4' diameter oak just next } \\
\text { on greench bench by walkway }\end{array}$ & 34.00068 & -81.01493 \\
\hline 11134 & Rocky Branch & 14349 & Seed line & Good & SC-RIC-702A; USPS in 5 Pts loading dock & 34.00001 & -81.01576 \\
\hline 11135 & Rocky Branch & 14350 & Seed line & Fair & $\begin{array}{l}\text { SC-RIC-703A; Telephone pole btwn Harpers \& } \\
\text { BofA; Pole \# SCE\&G } 23783\end{array}$ & 33.99921 & -81.01533 \\
\hline 11136 & Rocky Branch & 14351 & Seed line & Good & $\begin{array}{l}\text { SC-RIC-704; seed line inside of the building/ } \\
\text { garage behind the house @ 621/623 Saluda Ave }\end{array}$ & 33.99771 & -81.01842 \\
\hline 11137 & Rocky Branch & 14352 & Seed line & Fair & $\begin{array}{l}\text { SC-RIC-704X; used } 704 \text { twice; railroad bridge } \\
\text { just above Maxcy Greg Park }\end{array}$ & 33.99678 & -81.01916 \\
\hline 11138 & Rocky Branch & 14353 & Seed line & Fair & $\begin{array}{l}\text { SC-RIC-705; In Maxcy Gregg Park on right } \\
\text { bank of Rocky Br across from Finley Tower }\end{array}$ & 33.99653 & -81.02034 \\
\hline 11139 & Rocky Branch & 14354 & Seed line & Good & $\begin{array}{l}\text { SC-RIC-706; in Maxcy Gregg Park next to } \\
\text { Blossom St }\end{array}$ & 33.99621 & -81.02186 \\
\hline 11140 & Rocky Branch & 14355 & Seed line & Good & $\begin{array}{l}\text { SC-RIC-707; Maxcy Gregg Park bridge . Pool } \\
\text { side, left bank }\end{array}$ & 33.99579 & -81.02187 \\
\hline
\end{tabular}


Appendix 1. High-water marks used to generate flood-inundation maps of selected areas affected by the flood of 0 ctober 2015 in central and coastal South Carolina.-Continued

[Methods for data collection for high-water marks are described in Rydlund and Densmore, 2012. Horizontal coordinate information is referenced to the North American Datum of 1983 (NAD 83). Vertical coordinate information is referenced to the North American Vertical Datum of 1988 (NAVD 88).

Location descriptions and HWM notes may be truncated. Abbreviations: ID, identification; HWM, high-water mark; Un. trib., unnamed tributary. -, no data]

\begin{tabular}{|c|c|c|c|c|c|c|c|}
\hline $\begin{array}{l}\text { Elevation } \\
\text { (feet) }\end{array}$ & Marker type & $\begin{array}{c}\text { Height } \\
\text { above } \\
\text { ground } \\
\text { (feet) }\end{array}$ & High-water mark notes & $\begin{array}{c}\text { HWM } \\
\text { environ- } \\
\text { ment }\end{array}$ & Flag date & Survey date & $\begin{array}{c}\text { Still } \\
\text { water }\end{array}$ \\
\hline 220.0 & Marker & 2.72 & Flagging \& marker & Urban & $10 / 9 / 2015$ & $10 / 15 / 2015$ & No \\
\hline 208.8 & Marker & 3.49 & Flagging \& marker & Urban & $10 / 9 / 2015$ & $10 / 15 / 2015$ & No \\
\hline 218.9 & Nail and HWM tag & 0 & Height not recorded & - & $10 / 9 / 2015$ & $10 / 15 / 2015$ & No \\
\hline 207.5 & Nail and HWM tag & 2.4 & Marker, nail and flagging & - & $10 / 9 / 2015$ & $10 / 15 / 2015$ & No \\
\hline 206.9 & Nail and HWM tag & 2.00 & Marker, nail and flagging & - & $10 / 9 / 2015$ & $10 / 15 / 2015$ & No \\
\hline
\end{tabular}

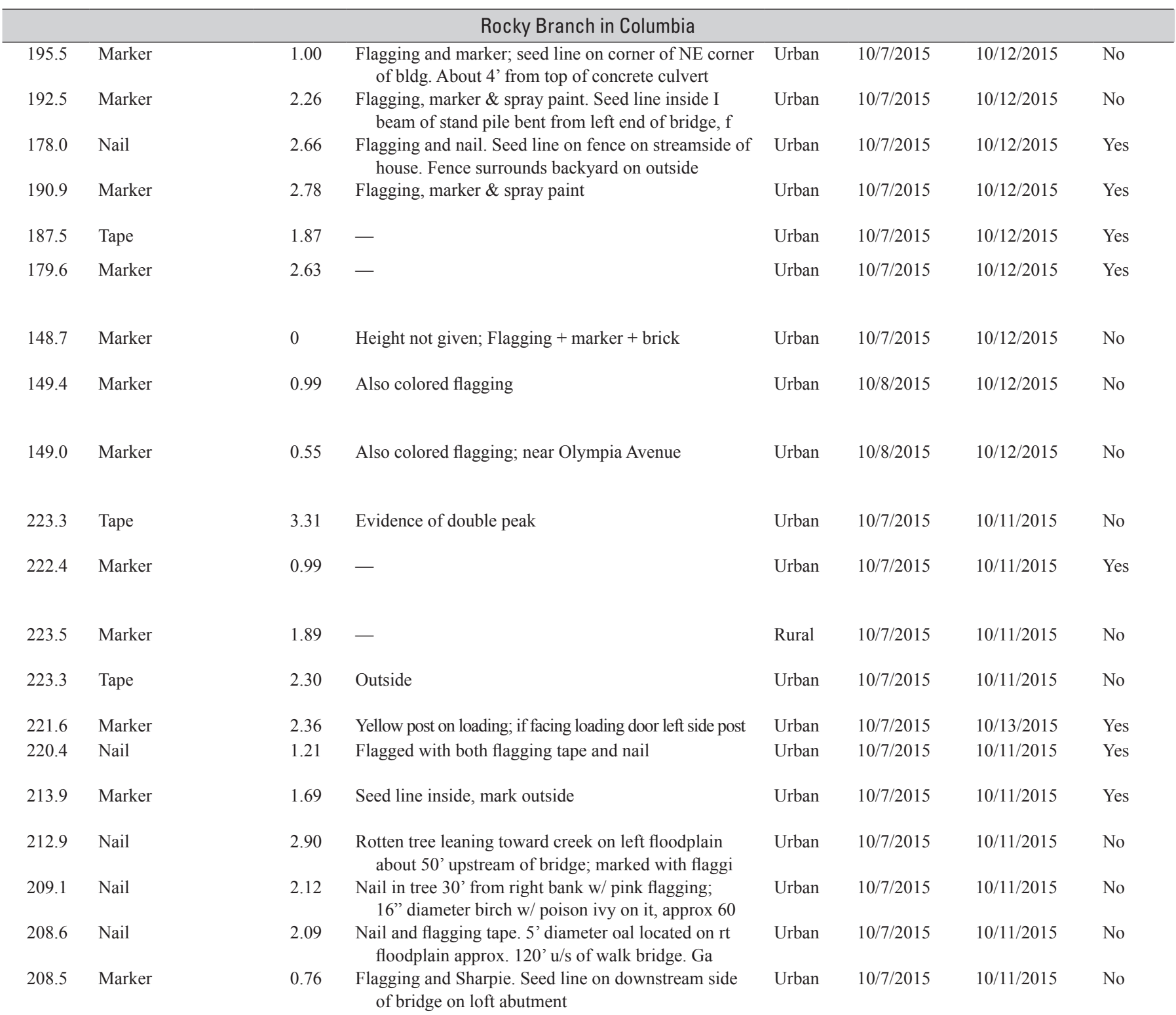


Appendix 1. High-water marks used to generate flood-inundation maps of selected areas affected by the flood of 0 ctober 2015 in central and coastal South Carolina.-Continued

[Methods for data collection for high-water marks are described in Rydlund and Densmore, 2012. Horizontal coordinate information is referenced to the North American Datum of 1983 (NAD 83). Vertical coordinate information is referenced to the North American Vertical Datum of 1988 (NAVD 88).

Location descriptions and HWM notes may be truncated. Abbreviations: ID, identification; HWM, high-water mark; Un. trib., unnamed tributary. -, no data]

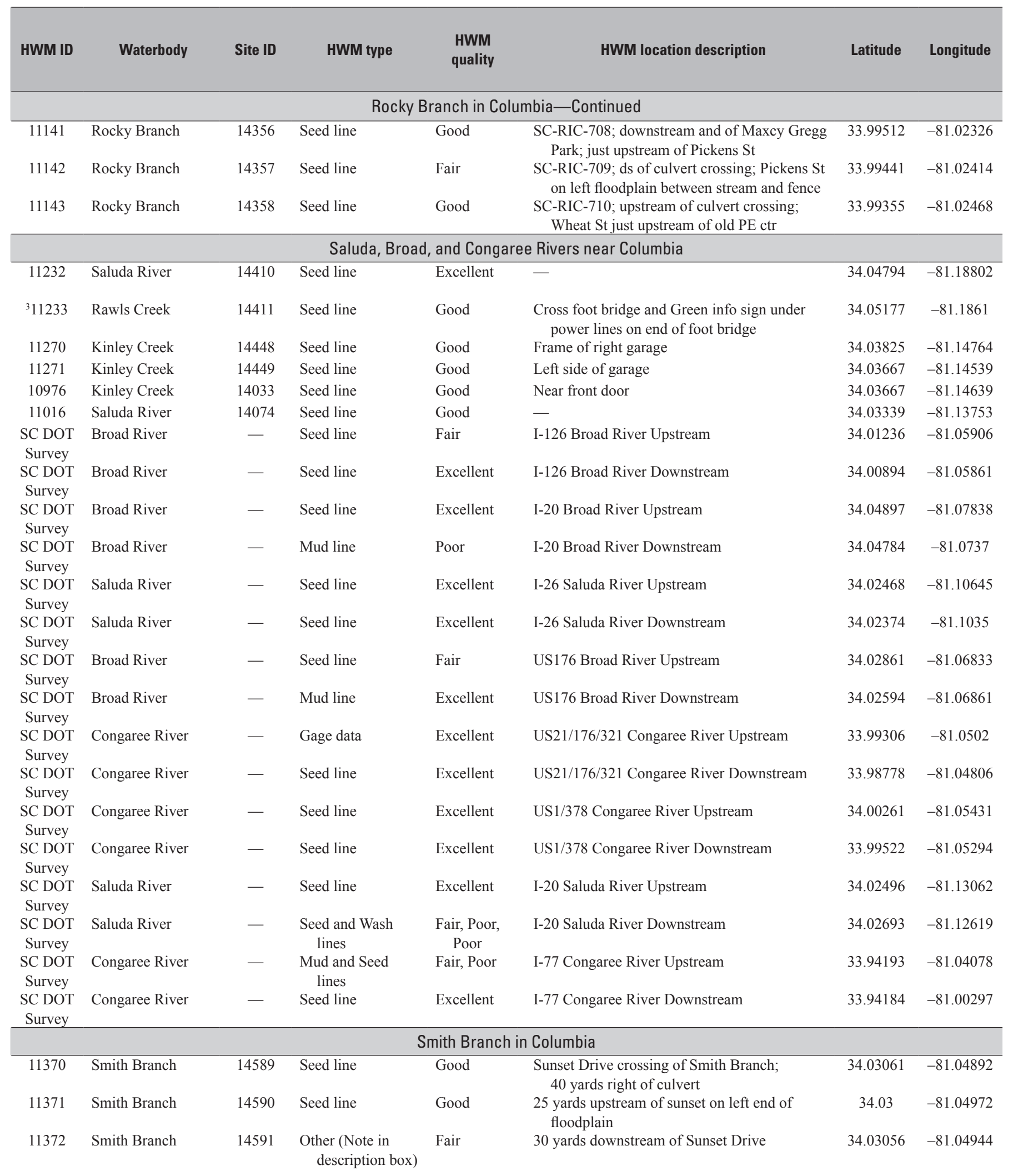


Appendix 1. High-water marks used to generate flood-inundation maps of selected areas affected by the flood of 0 ctober 2015 in central and coastal South Carolina.-Continued

[Methods for data collection for high-water marks are described in Rydlund and Densmore, 2012. Horizontal coordinate information is referenced to the North American Datum of 1983 (NAD 83). Vertical coordinate information is referenced to the North American Vertical Datum of 1988 (NAVD 88).

Location descriptions and HWM notes may be truncated. Abbreviations: ID, identification; HWM, high-water mark; Un. trib., unnamed tributary. -, no data]

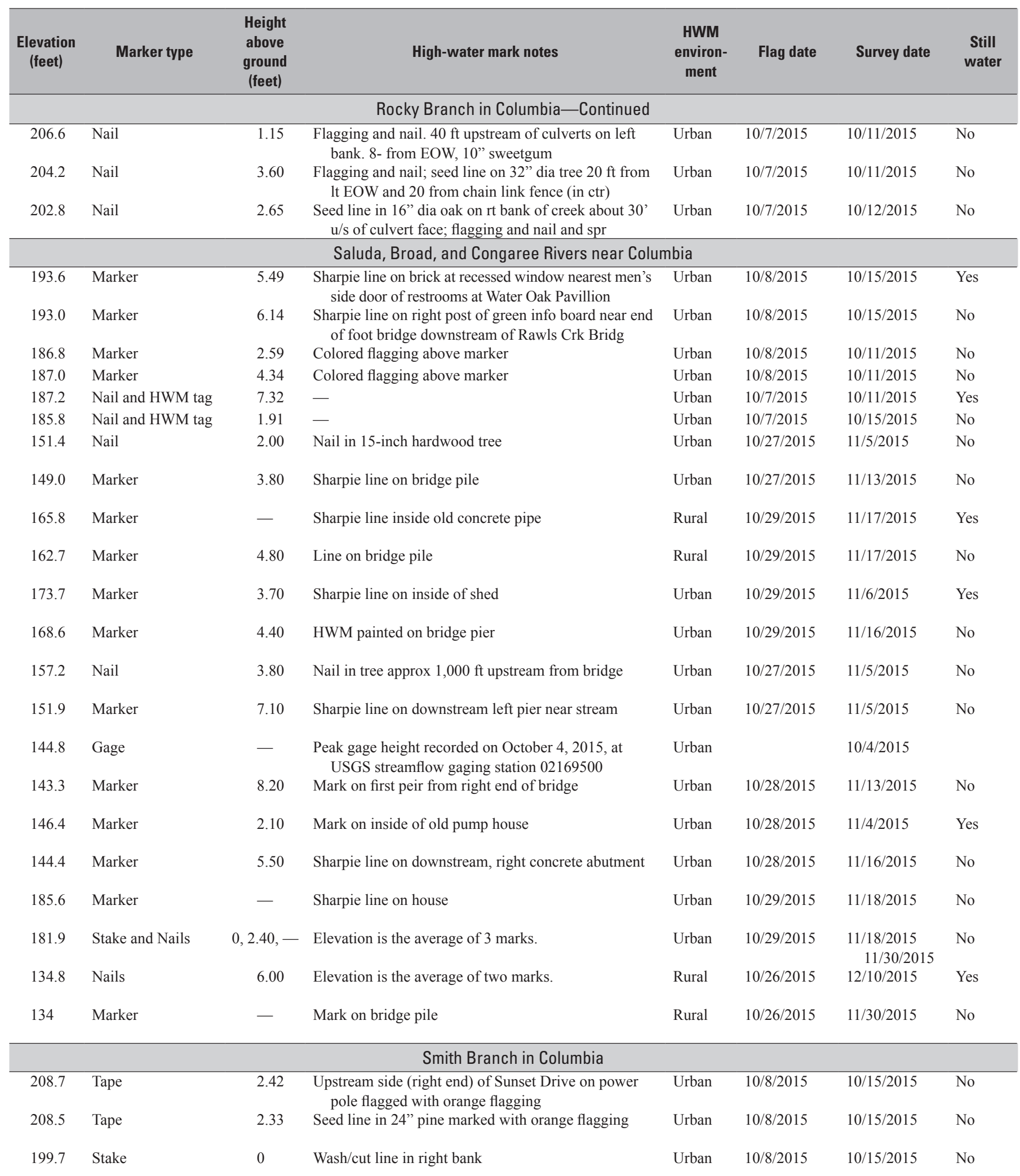


Appendix 1. High-water marks used to generate flood-inundation maps of selected areas affected by the flood of October 2015 in central and coastal South Carolina.-Continued

[Methods for data collection for high-water marks are described in Rydlund and Densmore, 2012. Horizontal coordinate information is referenced to the North American Datum of 1983 (NAD 83). Vertical coordinate information is referenced to the North American Vertical Datum of 1988 (NAVD 88).

Location descriptions and HWM notes may be truncated. Abbreviations: ID, identification; HWM, high-water mark; Un. trib., unnamed tributary. -, no data]

\begin{tabular}{|c|c|c|c|c|c|c|c|}
\hline HWM ID & Waterbody & Site ID & HWM type & $\begin{array}{l}\text { HWM } \\
\text { quality }\end{array}$ & HWM location description & Latitude & Longitude \\
\hline 11373 & Smith Branch & 14592 & Seed line & Good & SC-RIC-815-A; approx 200 yards from road & 34.03139 & -81.05333 \\
\hline 11374 & Smith Branch & 14593 & Seed line & Excellent & $35-40$ yards behind house & 34.03556 & -81.05583 \\
\hline 11376 & Smith Branch & 14595 & Seed line & Excellent & $\begin{array}{l}40 \text { yards downstream of Clement } \mathrm{Rd} \text { near } \\
\text { Mountain Dr }\end{array}$ & 34.03861 & -81.06056 \\
\hline 11377 & Smith Branch & 14596 & Seed line & Good & Behind house & 34.03722 & -81.06611 \\
\hline 11079 & Smith Branch & 14131 & Seed line & Fair & $\begin{array}{l}\text { SC-RIC-804-A; 20' away from Harden St Ext } \\
3440 \text { SC Department of Disabilities and } \\
\text { Speacial Needs Sign }\end{array}$ & 34.02586 & -81.03319 \\
\hline 11081 & Smith Branch & 14132 & Seed line & VP & $\begin{array}{l}\text { SC-RIC-805-A; } 400 \text { yards away from } \\
\text { Harden St Ext }\end{array}$ & 34.02506 & -81.03186 \\
\hline 11082 & Smith Branch & 14132 & Seed line & VP & $\begin{array}{l}\text { SC-RIC-805-B; } 400 \text { yards away from } \\
\text { Harden St Ext }\end{array}$ & 34.02489 & -81.03189 \\
\hline 11084 & Smith Branch & 14134 & Seed line & Good & SC-RIC-807A: Rt flood plain, culvert exit & 34.02569 & -81.03467 \\
\hline 11085 & Smith Branch & 14134 & Seed line & Good & SC-RIC-807B: Left flood plain, culvert exit & 34.02569 & -81.03467 \\
\hline 11086 & Smith Branch & 14135 & $\begin{array}{l}\text { Other (Note in } \\
\text { description box) }\end{array}$ & Excellent & - & 34.02733 & -81.04189 \\
\hline 12070 & Smith Branch & 15348 & Debris & Fair & Earlewood Park about 200-300 ft DS of gage & 34.02833 & -81.0425 \\
\hline \multicolumn{8}{|c|}{ Stoop Creek near Columbia } \\
\hline 10950 & Stoop Creek & 14008 & Seed line & Good & $\begin{array}{l}\text { Inside waste water treatment plant at tan metal } \\
\text { building behind holding tank "B". }\end{array}$ & 34.029 & -81.11461 \\
\hline 10951 & Stoop Creek & 14009 & Seed line & Fair & Between residences 1905 and 1915 in vacant lot & 34.03214 & -81.11400 \\
\hline 10952 & Stoop Creek & 14010 & Seed line & Good & $\begin{array}{l}\text { SC-LEX-603-A; Back of property inside } \\
6 \text { foot chain link fence on } 20 \text { ton A/C unit; } \\
\text { streamward side of }\end{array}$ & 34.03319 & -81.11797 \\
\hline 10970 & Stoop Creek & 14028 & Seed line & Good & SC-LEX-604A; On back of Jones \& Frank building. & 34.03361 & -81.11556 \\
\hline 10971 & Stoop Creek & 14028 & Seed line & $\begin{array}{l}\text { Unknown/ } \\
\text { historical }\end{array}$ & $\begin{array}{l}\text { SC-LEX-604B; At warehouse entrance at Jones } \\
\text { \& Frank at DSS of loading dock }\end{array}$ & 34.03333 & -81.11556 \\
\hline 10972 & Stoop Creek & 14029 & Debris & Poor & At base of tree & 34.03944 & -81.11472 \\
\hline 10973 & Stoop Creek & 14030 & Seed line & Good & On large green power box labeled 156-2-39 & 34.03564 & -81.11628 \\
\hline 10974 & Stoop Creek & 14031 & Debris & Fair & $\begin{array}{l}\text { Power pole number 156-02-007 located behind } \\
\text { first building left of leasing office and pool }\end{array}$ & 34.03722 & -81.11528 \\
\hline 10975 & Stoop Creek & 14032 & Seed line & Good & On house corner, right of right garage door & 34.03972 & -81.11667 \\
\hline 11467 & Stoop Creek & 14764 & Seed line & Good & $\begin{array}{l}\text { Willow Creek Apts; seed line located on } \\
\text { building across from apt } 106\end{array}$ & 34.04816 & -81.11783 \\
\hline 11468 & Stoop Creek & 14765 & Seed line & Good & $\begin{array}{l}\text { Residence on } 433 \text { Brookgreen Dr; seed line } \\
\text { located on back of home }\end{array}$ & 34.06182 & -81.12166 \\
\hline 11469 & Stoop Creek & 14766 & Seed line & Good & $\begin{array}{l}\text { Residence at } 4512 \text { Bonnie Forest Blvd; Seed } \\
\text { line located of southwest front corner of } \\
\text { home on gutter d }\end{array}$ & 34.06377 & -81.1236 \\
\hline 11470 & Stoop Creek & 14767 & Seed line & Good & $\begin{array}{l}\text { Residence located at } 4716 \text { Bonnie Forest Blvd. } \\
\text { Seed line located on garage door molding. }\end{array}$ & 34.06657 & -81.12586 \\
\hline
\end{tabular}


Appendix 1. High-water marks used to generate flood-inundation maps of selected areas affected by the flood of 0 ctober 2015 in central and coastal South Carolina.-Continued

[Methods for data collection for high-water marks are described in Rydlund and Densmore, 2012. Horizontal coordinate information is referenced to the North American Datum of 1983 (NAD 83). Vertical coordinate information is referenced to the North American Vertical Datum of 1988 (NAVD 88).

Location descriptions and HWM notes may be truncated. Abbreviations: ID, identification; HWM, high-water mark; Un. trib., unnamed tributary. -, no data]

\begin{tabular}{|c|c|c|c|c|c|c|c|}
\hline $\begin{array}{l}\text { Elevation } \\
\text { (feet) }\end{array}$ & Marker type & $\begin{array}{c}\text { Height } \\
\text { above } \\
\text { ground } \\
\text { (feet) }\end{array}$ & High-water mark notes & $\begin{array}{l}\text { HWM } \\
\text { environ- } \\
\text { ment }\end{array}$ & Flag date & Survey date & $\begin{array}{c}\text { Still } \\
\text { water }\end{array}$ \\
\hline 187.6 & Tape & 2.67 & $\begin{array}{l}\text { Seed line on 7" sweetgum approx } 30 \text { yards from right } \\
\text { bank about } 15 \text { yards from manhole on utility line }\end{array}$ & Riverine & $10 / 8 / 2015$ & $10 / 16 / 2015$ & No \\
\hline 180.1 & Marker & 1.58 & $\begin{array}{l}\text { Good seed line on privacy fencse about } 35 \text { yards from } \\
\text { back of house }\end{array}$ & Urban & $10 / 8 / 2015$ & $10 / 15 / 2015$ & No \\
\hline 174.3 & Marker & 2.80 & $\begin{array}{l}\text { Seed line on storage building (streamward side) about } \\
25 \text { yards right of Mountain Dr }\end{array}$ & Urban & $10 / 8 / 2015$ & $10 / 11 / 2015$ & No \\
\hline 165.6 & Nail & 4.67 & $\begin{array}{l}\text { Seed/mudline on } 14 \text { " sweetgum tree on top left bank } \\
\text { behind house }\end{array}$ & Urban & $10 / 8 / 2015$ & $10 / 11 / 2015$ & No \\
\hline 220.7 & Tape & 1.50 & - & Urban & $10 / 7 / 2015$ & $10 / 11 / 2015$ & No \\
\hline 220.9 & Tape & 2.67 & $\begin{array}{l}\text { Cluster of pines before chain link fence, between } \\
\text { parking and Smith Branch }\end{array}$ & Urban & $10 / 7 / 2015$ & $10 / 12 / 2015$ & No \\
\hline 220.9 & Tape & 2.33 & $\begin{array}{l}\text { Cluster of pines before chain link fence, between } \\
\text { parking and Smith Branch }\end{array}$ & Urban & $10 / 7 / 2015$ & $10 / 12 / 2015$ & No \\
\hline 220.3 & Tape & 2.00 & This HWM associated with field notes for SC-RIC- 807 . & Riverine & $10 / 7 / 2015$ & $10 / 11 / 2015$ & No \\
\hline 219.3 & Tape & 1.83 & $\begin{array}{l}\text { This HWM associated with field notes for SC-RIC-808, } \\
\text { but since at same location as SC-RIC-807A consi }\end{array}$ & Riverine & $10 / 7 / 2015$ & $10 / 11 / 2015$ & No \\
\hline 218.6 & Paint & 2.17 & Trashline marked with paint and colored flagging & Urban & $10 / 7 / 2015$ & $10 / 15 / 2015$ & No \\
\hline 210.1 & Stake & 0 & $\begin{array}{l}\text { Good trash line on DS right bank below gage at } \\
\text { Earlewood Park }\end{array}$ & Urban & $10 / 15 / 2015$ & $10 / 15 / 2015$ & No \\
\hline 186.6 & Marker & 1.52 & - & Urban & $10 / 7 / 2015$ & $10 / 11 / 2015$ & Yes \\
\hline 186.0 & Marker & 2.00 & - & Urban & $10 / 7 / 2015$ & $10 / 11 / 2015$ & Yes \\
\hline 187.5 & Nail and HWM tag & 1.22 & Nail with green disc, pink flagging & Urban & $10 / 7 / 2015$ & $10 / 11 / 2015$ & No \\
\hline 192.3 & Marker & 1.30 & Marker and orange paint & Urban & $10 / 7 / 2015$ & $10 / 11 / 2015$ & Yes \\
\hline 193.4 & Nail and HWM tag & 1.87 & - & Urban & $10 / 7 / 2015$ & $10 / 11 / 2015$ & No \\
\hline 199.0 & Marker & 2.12 & $\begin{array}{l}\text { Marked small with sharpie to minimize disturbance } \\
\text { to home }\end{array}$ & - & $10 / 7 / 2015$ & $10 / 11 / 2015$ & Yes \\
\hline 217.0 & Stake & 4.35 & Stake, flagging, marker & Urban & $10 / 9 / 2015$ & $10 / 14 / 2015$ & No \\
\hline 241.1 & Marker & 2.70 & Flagging \& marker & Urban & $10 / 9 / 2015$ & $10 / 14 / 2015$ & No \\
\hline 241.9 & Marker & 1.39 & Flagging \& marker & Urban & $10 / 9 / 2015$ & $10 / 14 / 2015$ & No \\
\hline 249.0 & Marker & 1.41 & Flagging \& marker & Urban & $10 / 9 / 2015$ & $10 / 14 / 2015$ & No \\
\hline
\end{tabular}


Appendix 1. High-water marks used to generate flood-inundation maps of selected areas affected by the flood of October 2015 in central and coastal South Carolina.-Continued

[Methods for data collection for high-water marks are described in Rydlund and Densmore, 2012. Horizontal coordinate information is referenced to the North American Datum of 1983 (NAD 83). Vertical coordinate information is referenced to the North American Vertical Datum of 1988 (NAVD 88).

Location descriptions and HWM notes may be truncated. Abbreviations: ID, identification; HWM, high-water mark; Un. trib., unnamed tributary. -, no data]

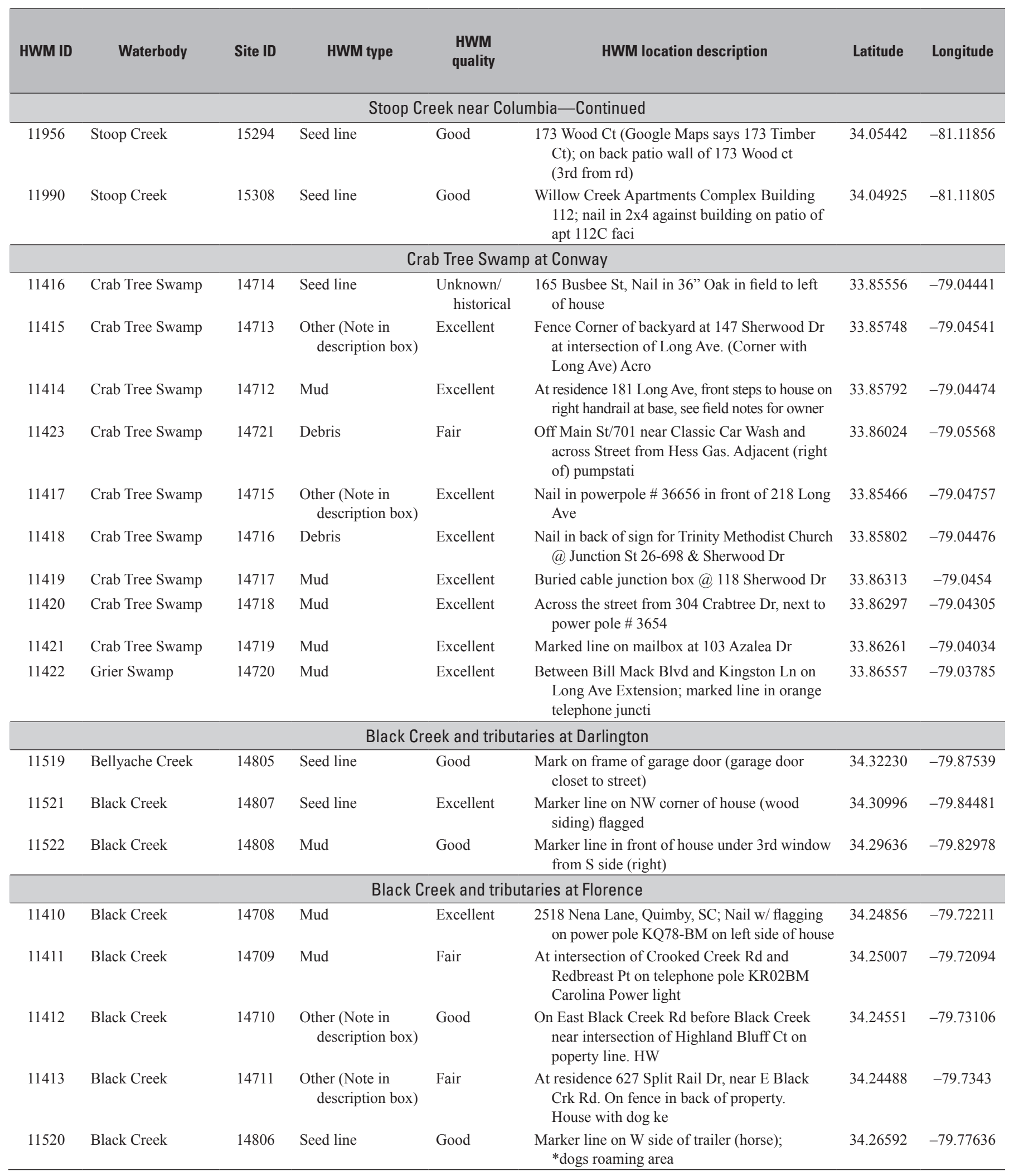


Appendix 1. High-water marks used to generate flood-inundation maps of selected areas affected by the flood of October 2015 in central and coastal South Carolina.-Continued

[Methods for data collection for high-water marks are described in Rydlund and Densmore, 2012. Horizontal coordinate information is referenced to the North American Datum of 1983 (NAD 83). Vertical coordinate information is referenced to the North American Vertical Datum of 1988 (NAVD 88).

Location descriptions and HWM notes may be truncated. Abbreviations: ID, identification; HWM, high-water mark; Un. trib., unnamed tributary. -, no data]

\begin{tabular}{|c|c|c|c|c|c|c|c|}
\hline $\begin{array}{c}\text { Elevation } \\
\text { (feet) }\end{array}$ & Marker type & $\begin{array}{c}\text { Height } \\
\text { above } \\
\text { ground } \\
\text { (feet) }\end{array}$ & High-water mark notes & $\begin{array}{c}\text { HWM } \\
\text { environ- } \\
\text { ment }\end{array}$ & Flag date & Survey date & $\begin{array}{c}\text { Still } \\
\text { wate }\end{array}$ \\
\hline 224.4 & Nail and HWM tag & 2.30 & Marker, nail and flagging & - & $10 / 9 / 2015$ & $10 / 14 / 2015$ & No \\
\hline
\end{tabular}

\begin{tabular}{|c|c|c|c|c|c|c|c|}
\hline \multicolumn{8}{|c|}{ Crab Tree Swamp at Conway } \\
\hline 10.3 & Tape & 2.82 & - & Urban & $10 / 8 / 2015$ & $10 / 15 / 2015$ & Yes \\
\hline 11.0 & Nail & 1.65 & Seed line \& debris line; Flagging and nail & Rural & $10 / 8 / 2015$ & $10 / 16 / 2015$ & Yes \\
\hline 10.9 & Nail & 0.72 & Flagging and nail & Rural & $10 / 8 / 2015$ & $10 / 16 / 2015$ & Yes \\
\hline 10.9 & Nail & 1.74 & Seed line $\&$ debris line; Flagging and nail & Rural & $10 / 8 / 2015$ & $10 / 15 / 2015$ & Yes \\
\hline 10.8 & Nail & 1.54 & Flagging, marker, and nail & Urban & $10 / 8 / 2015$ & $10 / 16 / 2015$ & Yes \\
\hline 11.5 & Marker & 1.24 & Flagging and sharpie & Urban & $10 / 8 / 2015$ & $10 / 15 / 2015$ & Yes \\
\hline \multicolumn{8}{|c|}{ Black Creek and tributaries at Darlington } \\
\hline 116.0 & Marker & 1.53 & Still water - yes in backyard & Urban & $10 / 9 / 2015$ & $10 / 12 / 2015$ & No \\
\hline 96.5 & Marker & 3.08 & Also colored flagging & Urban & $10 / 9 / 2015$ & $10 / 12 / 2015$ & No \\
\hline 92.1 & Marker & 1.04 & - & Urban & $10 / 9 / 2015$ & $10 / 12 / 2015$ & No \\
\hline \multicolumn{8}{|c|}{ Black Creek and tributaries at Florence } \\
\hline 72.1 & Nail & 1.70 & Debris \& Mudline Flagging and nail & Rural & $10 / 8 / 2015$ & $10 / 12 / 2015$ & Yes \\
\hline 80.9 & Marker & 3.10 & Also colored flagging & Rural & $10 / 9 / 2015$ & $10 / 13 / 2015$ & No \\
\hline
\end{tabular}


Appendix 1. High-water marks used to generate flood-inundation maps of selected areas affected by the flood of October 2015 in central and coastal South Carolina._- Continued

[Methods for data collection for high-water marks are described in Rydlund and Densmore, 2012. Horizontal coordinate information is referenced to the North American Datum of 1983 (NAD 83). Vertical coordinate information is referenced to the North American Vertical Datum of 1988 (NAVD 88).

Location descriptions and HWM notes may be truncated. Abbreviations: ID, identification; HWM, high-water mark; Un. trib., unnamed tributary. -, no data]

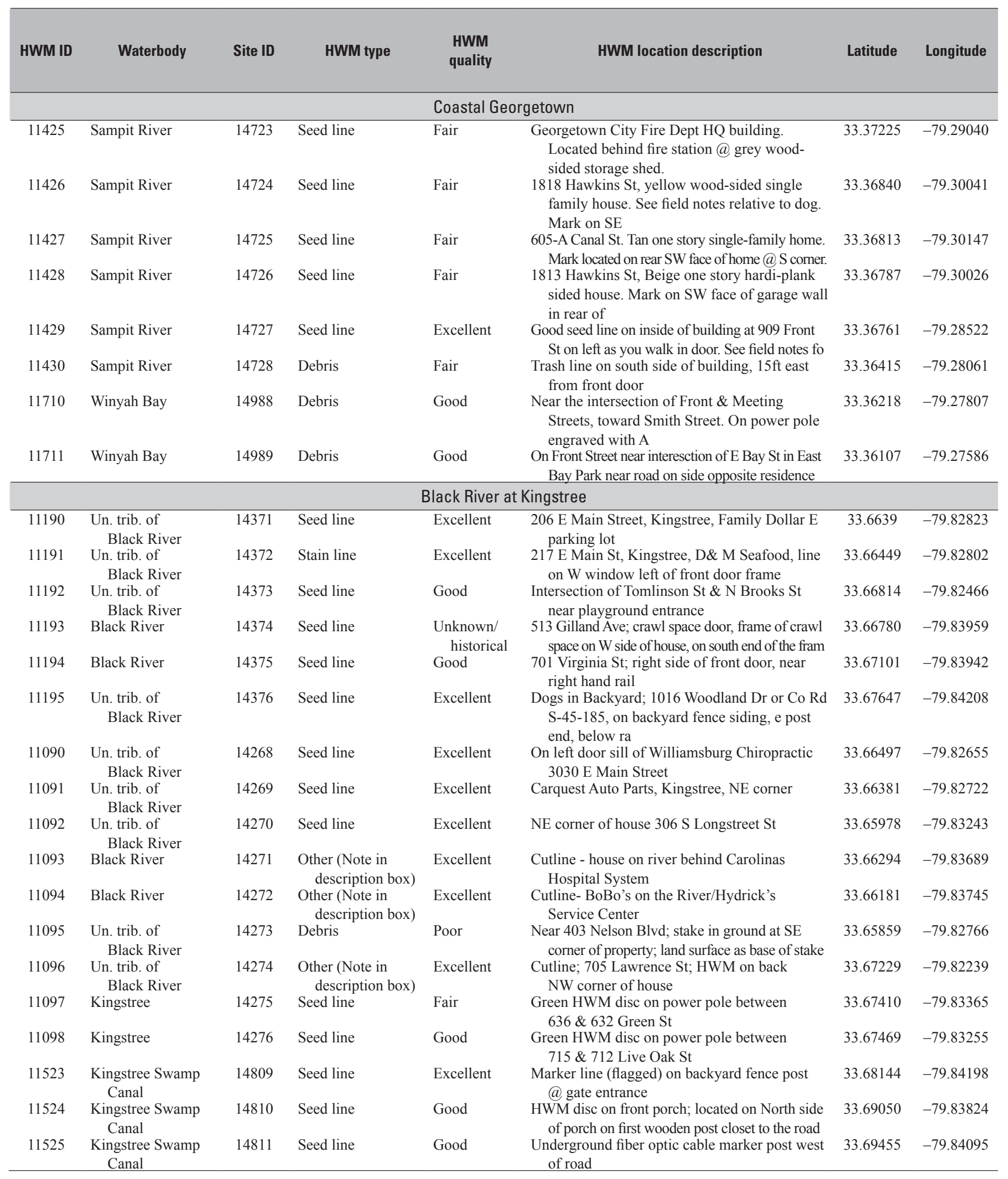


Appendix 1. High-water marks used to generate flood-inundation maps of selected areas affected by the flood of October 2015 in central and coastal South Carolina.-Continued

[Methods for data collection for high-water marks are described in Rydlund and Densmore, 2012. Horizontal coordinate information is referenced to the North American Datum of 1983 (NAD 83). Vertical coordinate information is referenced to the North American Vertical Datum of 1988 (NAVD 88).

Location descriptions and HWM notes may be truncated. Abbreviations: ID, identification; HWM, high-water mark; Un. trib., unnamed tributary. - , no data]

\begin{tabular}{|c|c|c|c|c|c|c|c|}
\hline $\begin{array}{l}\text { Elevation } \\
\text { (feet) }\end{array}$ & Marker type & $\begin{array}{c}\text { Height } \\
\text { above } \\
\text { ground } \\
\text { (feet) }\end{array}$ & High-water mark notes & $\begin{array}{c}\text { HWM } \\
\text { environ- } \\
\text { ment }\end{array}$ & Flag date & Survey date & $\begin{array}{c}\text { Still } \\
\text { water }\end{array}$ \\
\hline 8.6 & Marker & 1.72 & $\begin{array}{l}\text { Flood water was due to heavy rains causing drainage } \\
\text { basins to back up and pool water in city streets }\end{array}$ & Urban & $10 / 9 / 2015$ & $10 / 13 / 2015$ & Yes \\
\hline 14.6 & Marker & 3.63 & $\begin{array}{l}\text { Flagging \& Marker. Heavy rain and poor drainage } \\
\text { attributed to flood water }\end{array}$ & Urban & $10 / 9 / 2015$ & $10 / 13 / 2015$ & Yes \\
\hline 14.5 & Marker & 3.22 & $\begin{array}{l}\text { Flagging \& Marker. Poor drainage and heavy rain } \\
\text { caused storm drains to back up }\end{array}$ & Urban & $10 / 9 / 2015$ & $10 / 13 / 2015$ & Yes \\
\hline 4.8 & Marker & 1.65 & - & Urban & $10 / 9 / 2015$ & $10 / 13 / 2015$ & Yes \\
\hline 4.8 & Nail & 1.87 & Flagging and nail; due to street flooding & - & $10 / 9 / 2015$ & $10 / 16 / 2015$ & No \\
\hline \multicolumn{8}{|c|}{ Black River at Kingstree } \\
\hline 46.6 & Nail and HWM tag & 2.41 & $\begin{array}{l}\text { Seed line marked w/HWM disc + nail on wooden fence } \\
\text { around dumpster on E side of Family Dollar bldg }\end{array}$ & Urban & $10 / 8 / 2015$ & $10 / 8 / 2015$ & Yes \\
\hline 46.7 & Marker & 4.73 & Marker line on W window (left of front door) frame & Urban & $10 / 8 / 2015$ & $10 / 8 / 2015$ & Yes \\
\hline 46.8 & $\begin{array}{l}\text { Other (Note in } \\
\text { description box) }\end{array}$ & 0.53 & $\begin{array}{l}\text { Marker and flagging on white fence, on 1st post } \\
\text { closest to road }\end{array}$ & Urban & $10 / 8 / 2015$ & $10 / 13 / 2015$ & No \\
\hline 48.1 & Marker & 4.04 & - & Urban & $10 / 8 / 2015$ & $10 / 13 / 2015$ & Yes \\
\hline 46.7 & Marker & 3.30 & Sharpie line NE corner of house & - & $10 / 8 / 2015$ & $10 / 14 / 2015$ & No \\
\hline 47.7 & $\begin{array}{l}\text { Other (Note in } \\
\text { description box) }\end{array}$ & 4.00 & Pencil Mark on left door sill in back of the house & Urban & $10 / 8 / 2015$ & $10 / 14 / 2015$ & Yes \\
\hline 47.2 & Marker & 2.08 & Sharpie on SE Corner of buildig & Urban & $10 / 8 / 2015$ & $10 / 14 / 2015$ & No \\
\hline 46.7 & Stake & 0 & Picture card says 114 & - & $10 / 8 / 2015$ & $10 / 14 / 2015$ & Yes \\
\hline 51.3 & Marker & 2.26 & Sharpie on back nw corner of house & Urban & $10 / 8 / 2015$ & $10 / 14 / 2015$ & Yes \\
\hline 63.8 & Nail and HWM tag & 1.60 & Green Disc Spray painted & Urban & $10 / 8 / 2015$ & $10 / 14 / 2015$ & Yes \\
\hline 64.2 & Nail and HWM tag & 1.20 & Green HWM disc & Urban & $10 / 8 / 2015$ & $10 / 14 / 2015$ & Yes \\
\hline 48.6 & Tape & 5.67 & Also marker & Urban & $10 / 9 / 2015$ & $10 / 13 / 2015$ & Yes \\
\hline 49.1 & Nail and HWM tag & 0.96 & - & Urban & $10 / 9 / 2015$ & $10 / 13 / 2015$ & No \\
\hline 49.0 & Marker & 1.30 & Also colored flagging & Urban & $10 / 9 / 2015$ & $10 / 13 / 2015$ & No \\
\hline
\end{tabular}


Appendix 1. High-water marks used to generate flood-inundation maps of selected areas affected by the flood of October 2015 in central and coastal South Carolina.-Continued

[Methods for data collection for high-water marks are described in Rydlund and Densmore, 2012. Horizontal coordinate information is referenced to the North American Datum of 1983 (NAD 83). Vertical coordinate information is referenced to the North American Vertical Datum of 1988 (NAVD 88).

Location descriptions and HWM notes may be truncated. Abbreviations: ID, identification; HWM, high-water mark; Un. trib., unnamed tributary. -, no data]

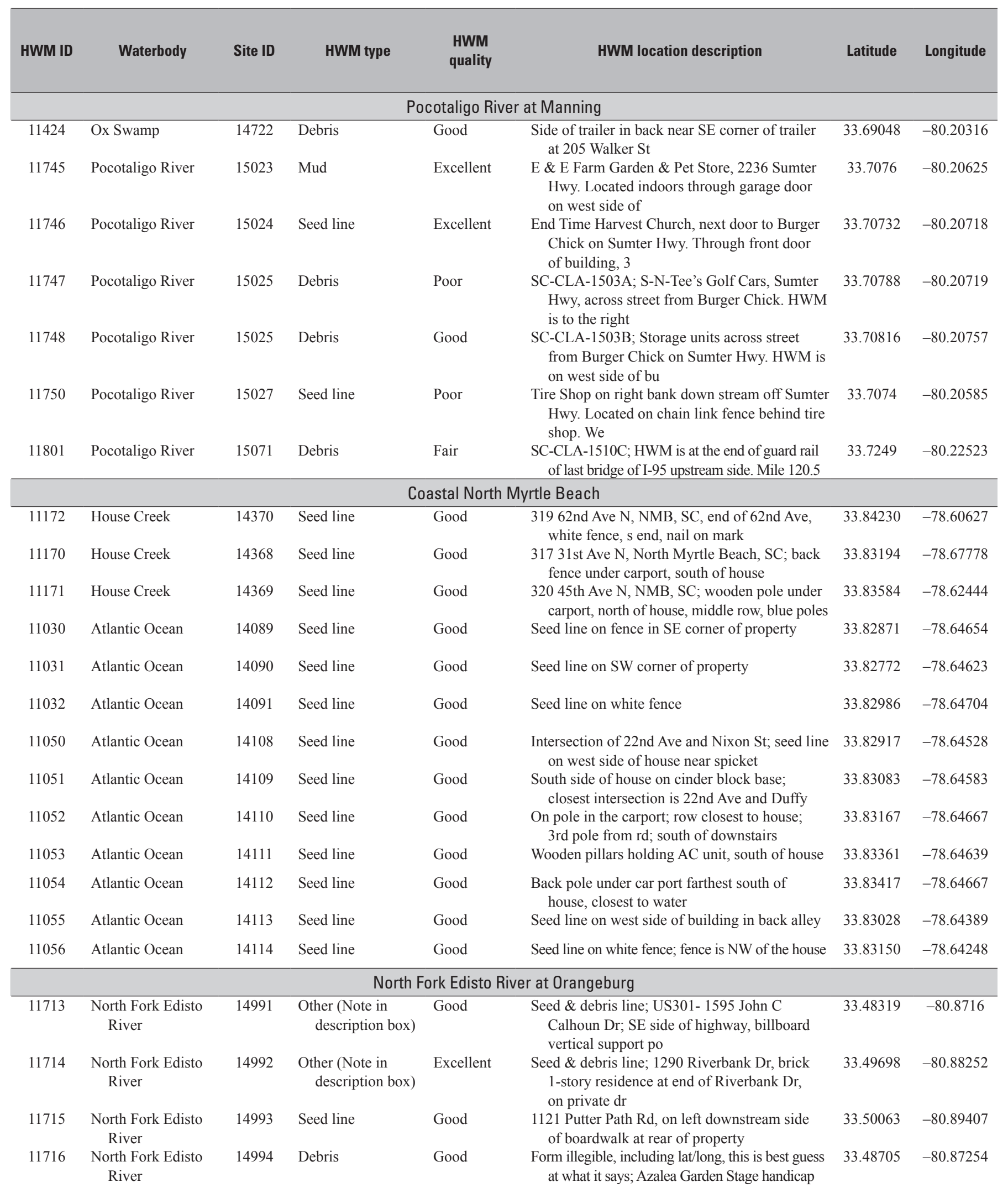


Appendix 1. High-water marks used to generate flood-inundation maps of selected areas affected by the flood of October 2015 in central and coastal South Carolina.-Continued

[Methods for data collection for high-water marks are described in Rydlund and Densmore, 2012. Horizontal coordinate information is referenced to the North American Datum of 1983 (NAD 83). Vertical coordinate information is referenced to the North American Vertical Datum of 1988 (NAVD 88).

Location descriptions and HWM notes may be truncated. Abbreviations: ID, identification; HWM, high-water mark; Un. trib., unnamed tributary. -, no data]

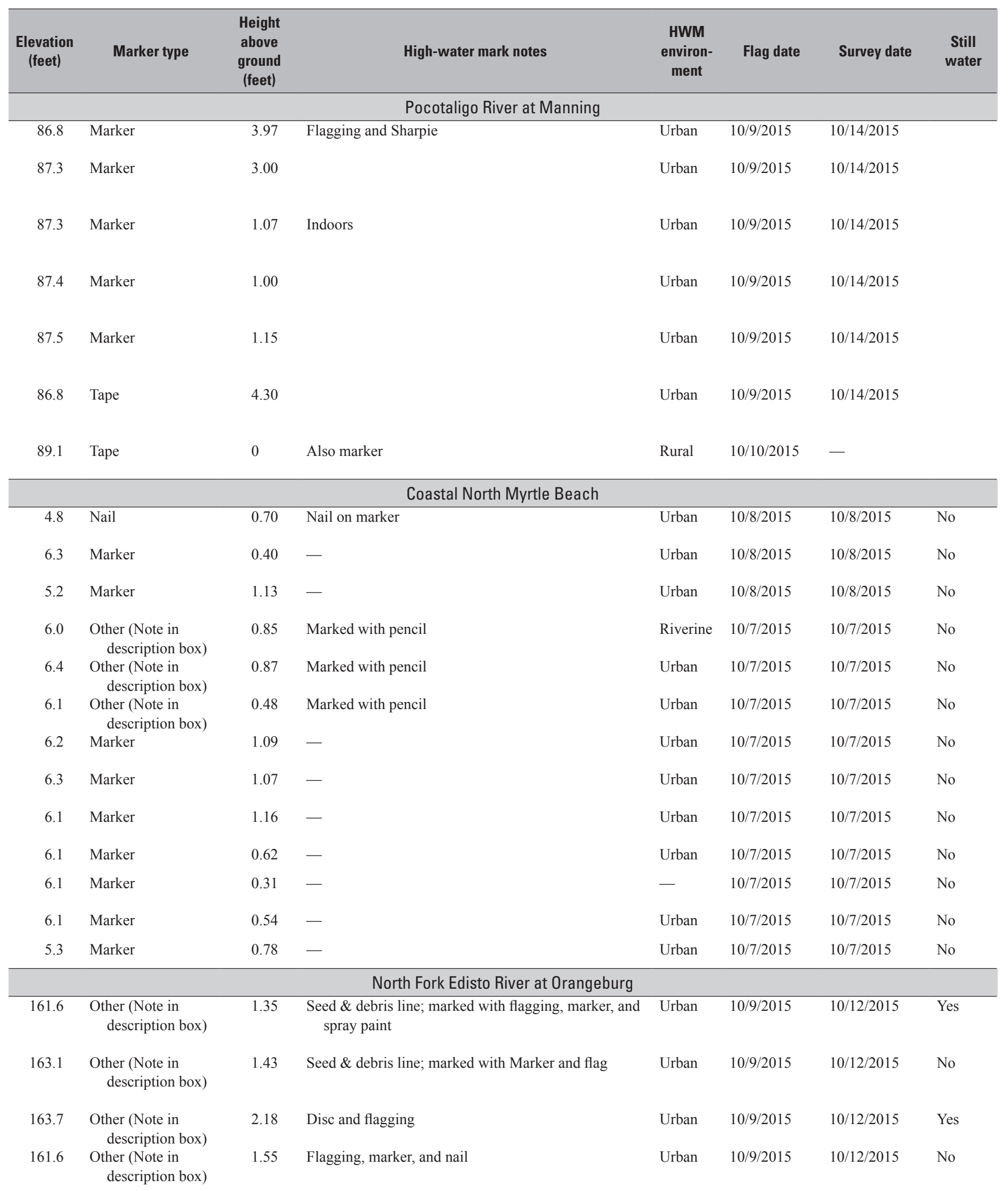


Appendix 1. High-water marks used to generate flood-inundation maps of selected areas affected by the flood of October 2015 in central and coastal South Carolina.-Continued

[Methods for data collection for high-water marks are described in Rydlund and Densmore, 2012. Horizontal coordinate information is referenced to the North American Datum of 1983 (NAD 83). Vertical coordinate information is referenced to the North American Vertical Datum of 1988 (NAVD 88).

Location descriptions and HWM notes may be truncated. Abbreviations: ID, identification; HWM, high-water mark; Un. trib., unnamed tributary. -, no data]

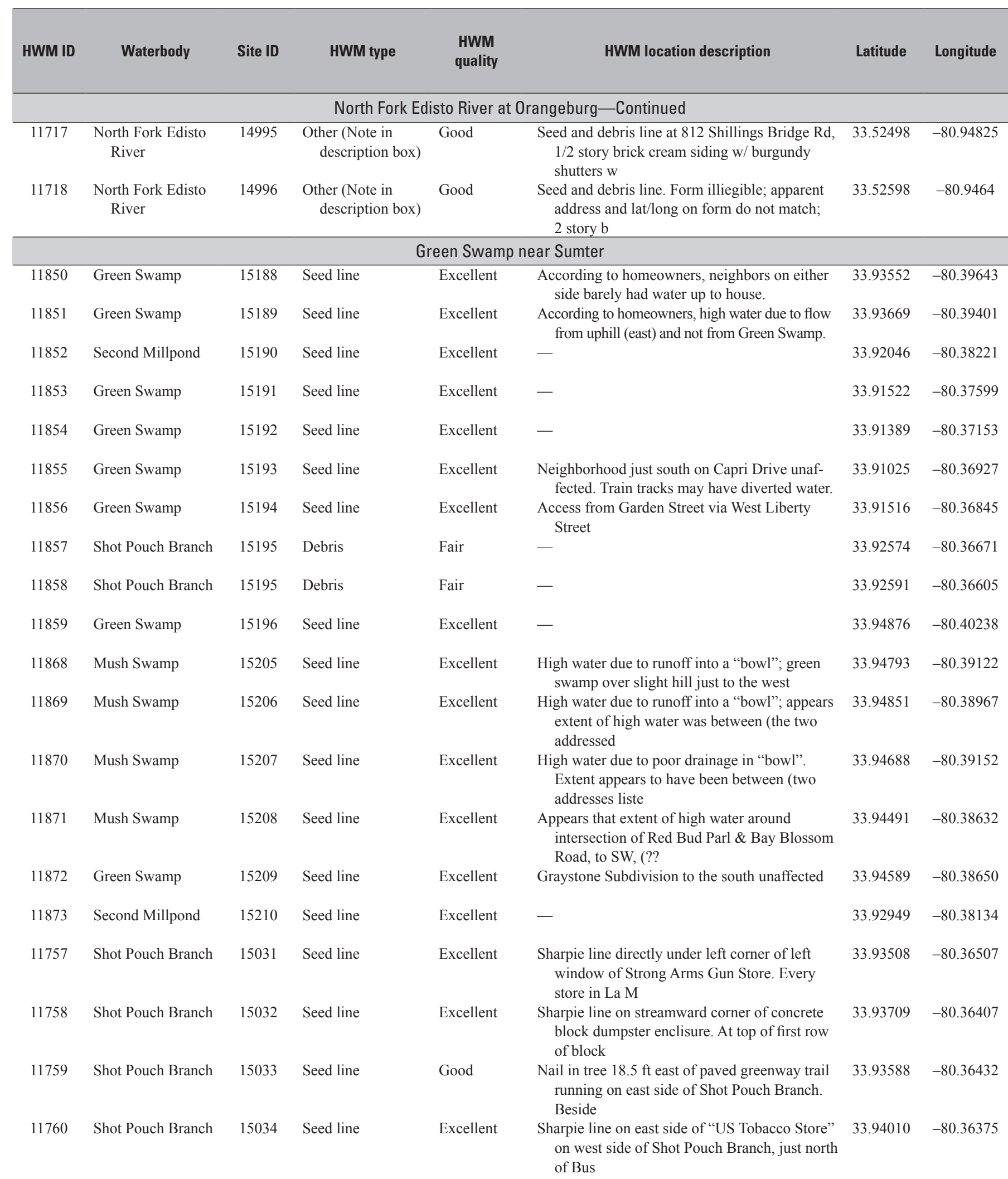


Appendix 1. High-water marks used to generate flood-inundation maps of selected areas affected by the flood of 0 ctober 2015 in central and coastal South Carolina.-Continued

[Methods for data collection for high-water marks are described in Rydlund and Densmore, 2012. Horizontal coordinate information is referenced to the North American Datum of 1983 (NAD 83). Vertical coordinate information is referenced to the North American Vertical Datum of 1988 (NAVD 88).

Location descriptions and HWM notes may be truncated. Abbreviations: ID, identification; HWM, high-water mark; Un. trib., unnamed tributary. -, no data]

\begin{tabular}{|c|c|c|c|c|c|c|c|}
\hline $\begin{array}{l}\text { Elevation } \\
\text { (feet) }\end{array}$ & Marker type & $\begin{array}{c}\text { Height } \\
\text { above } \\
\text { ground } \\
\text { (feet) }\end{array}$ & High-water mark notes & $\begin{array}{c}\text { HWM } \\
\text { environ- } \\
\text { ment }\end{array}$ & Flag date & Survey date & $\begin{array}{c}\text { Still } \\
\text { water }\end{array}$ \\
\hline 176.4 & Marker & 4.00 & Flagging and marker & Rural & $10 / 9 / 2015$ & $10 / 12 / 2015$ & No \\
\hline
\end{tabular}

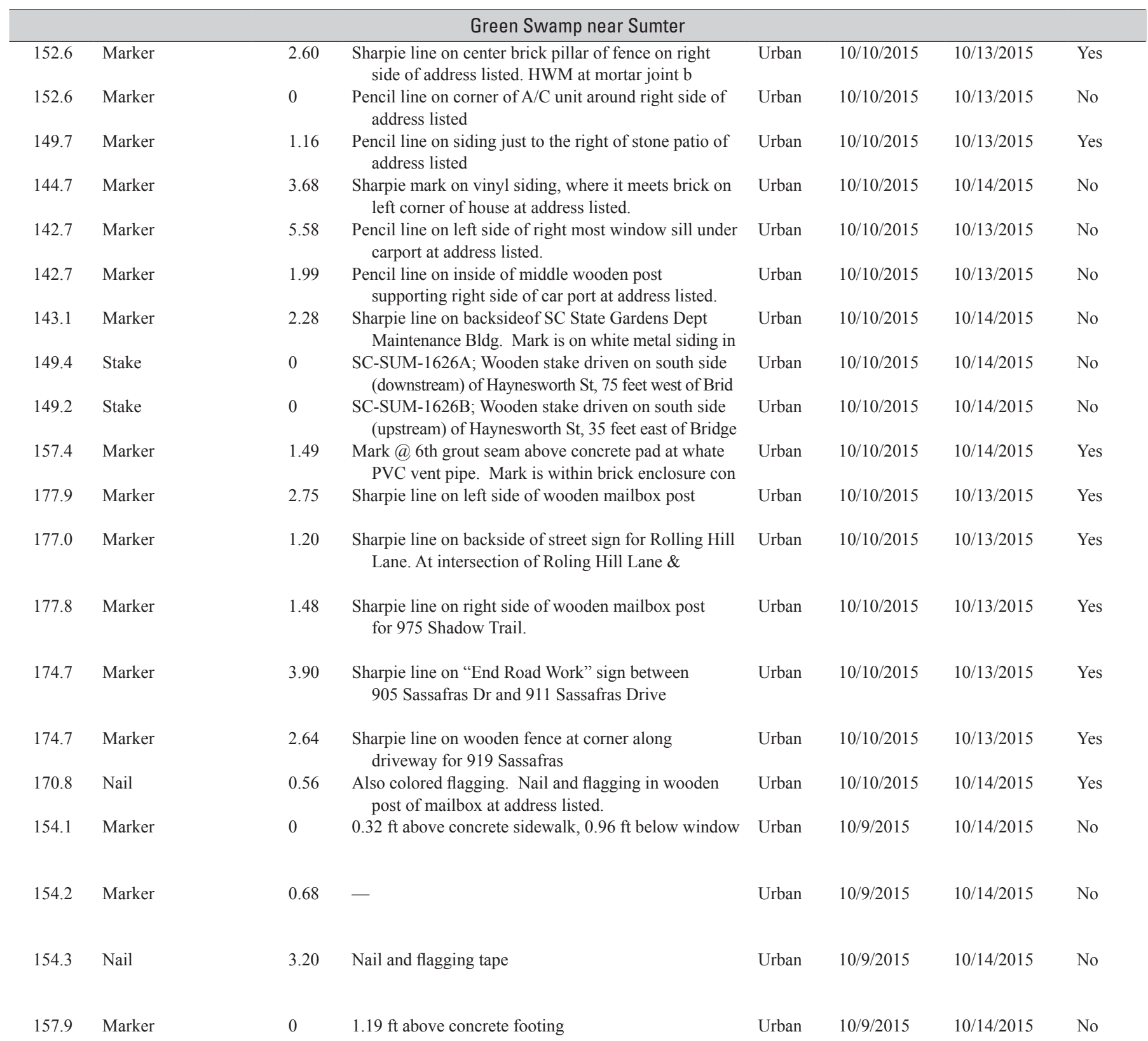


Appendix 1. High-water marks used to generate flood-inundation maps of selected areas affected by the flood of October 2015 in central and coastal South Carolina._- Continued

[Methods for data collection for high-water marks are described in Rydlund and Densmore, 2012. Horizontal coordinate information is referenced to the North American Datum of 1983 (NAD 83). Vertical coordinate information is referenced to the North American Vertical Datum of 1988 (NAVD 88).

Location descriptions and HWM notes may be truncated. Abbreviations: ID, identification; HWM, high-water mark; Un. trib., unnamed tributary. - , no data]

\begin{tabular}{|c|c|c|c|c|c|c|c|}
\hline HWM ID & Waterbody & Site ID & HWM type & $\begin{array}{l}\text { HWM } \\
\text { quality }\end{array}$ & HWM location description & Latitude & Longitude \\
\hline 11761 & Shot Pouch Branch & 15035 & Debris & Excellent & $\begin{array}{l}\text { Sharpie line on corner fence post of gated } \\
\text { opening of greenway. } 10.5 \mathrm{ft} \text { east of } \\
\text { greenway, and } 300 \mathrm{ft}\end{array}$ & 33.93414 & -80.36446 \\
\hline 11763 & Green Swamp & 15037 & Seed line & Excellent & $\begin{array}{l}\text { Sharpie line on metal side door frame on SE } \\
\text { side of Elks Lodge \# 855. There is a concrete } \\
\text { walkway th }\end{array}$ & 33.91626 & -80.38190 \\
\hline 11764 & Green Swamp & 15038 & Seed line & Excellent & $\begin{array}{l}978 \mathrm{~W} \text { Liberty St; Mark on back corner of } \\
\text { green shed behind house. Tenant took photos } \\
\text { during flooding }\end{array}$ & 33.91864 & -80.37939 \\
\hline 11766 & Green Swamp & 15040 & Seed line & Poor & $\begin{array}{l}\text { High water due to runoff into low lying area, } \\
\text { with RR tracks essentially acting as a dam. } \\
\text { Water was }\end{array}$ & 33.90953 & -80.38813 \\
\hline 11767 & Green Swamp & 15041 & Seed line & Good & $\begin{array}{l}\text { Homeowner blames runoff from construction } \\
\text { across the street for high water? Nail in } \\
\text { telephone pole o }\end{array}$ & 33.94329 & -80.38592 \\
\hline 11768 & Green Swamp & 15042 & Seed line & Excellent & $\begin{array}{l}\text { Almost entire street had water damage. Line } \\
\text { on fence marked with Sharpie right where } \\
\text { wooden fence me }\end{array}$ & 33.94217 & -80.38545 \\
\hline
\end{tabular}

${ }^{1}$ The elevation is based on the height above ground plus the elevation of the lidar based digital elevation model.

${ }^{2}$ Also used on Saluda, Broad, and Congaree Rivers near Columbia.

${ }^{3}$ Also used on Rawls Creek near Columbia. 
Appendix 1. High-water marks used to generate flood-inundation maps of selected areas affected by the flood of October 2015 in central and coastal South Carolina.-Continued

[Methods for data collection for high-water marks are described in Rydlund and Densmore, 2012. Horizontal coordinate information is referenced to the North American Datum of 1983 (NAD 83). Vertical coordinate information is referenced to the North American Vertical Datum of 1988 (NAVD 88).

Location descriptions and HWM notes may be truncated. Abbreviations: ID, identification; HWM, high-water mark; Un. trib., unnamed tributary. -, no data]

\begin{tabular}{|c|c|c|c|c|c|c|c|}
\hline $\begin{array}{l}\text { Elevation } \\
\text { (feet) }\end{array}$ & Marker type & $\begin{array}{c}\text { Height } \\
\text { above } \\
\text { ground } \\
\text { (feet) }\end{array}$ & High-water mark notes & $\begin{array}{c}\text { HWM } \\
\text { environ- } \\
\text { ment }\end{array}$ & Flag date & Survey date & $\begin{array}{c}\text { Still } \\
\text { water }\end{array}$ \\
\hline 152.1 & Marker & 1.24 & Marker and flagging tape & Urban & $10 / 9 / 2015$ & $10 / 14 / 2015$ & No \\
\hline 148.8 & Marker & 0.49 & - & Urban & $10 / 9 / 2015$ & $10 / 13 / 2015$ & Yes \\
\hline 146.1 & Marker & 4.45 & - & Urban & $10 / 9 / 2015$ & $10 / 13 / 2015$ & No \\
\hline 174.3 & Marker & 3.46 & $\begin{array}{l}\text { Marker and flagging tape; High water due to overflow } \\
\text { from north side of W Oakland Ave; appears to ha }\end{array}$ & Urban & $10 / 9 / 2015$ & $10 / 13 / 2015$ & Yes \\
\hline 174.8 & Nail & 2.42 & Nail and flagging tape & Urban & $10 / 9 / 2015$ & $10 / 13 / 2015$ & No \\
\hline 174.7 & Marker & 0.49 & - & Urban & $10 / 9 / 2015$ & $10 / 13 / 2015$ & Yes \\
\hline
\end{tabular}





\section{Appendix 2. Flood-Inundation Maps of Selected Areas in Central and Coastal South Carolina, October 1-5, 2015}




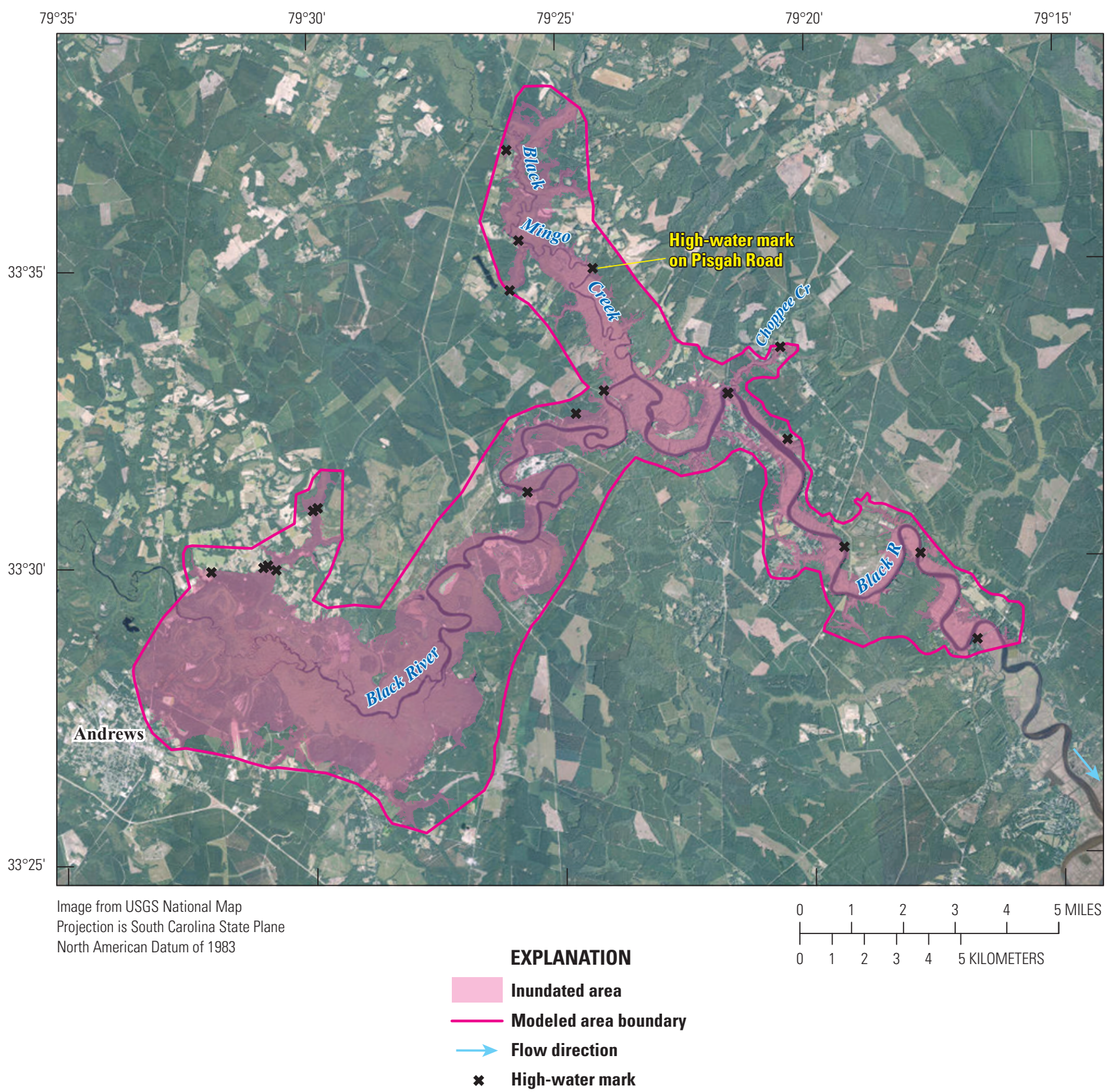

Figure 2-1. Flood-inundation map of the Black River near Andrews, South Carolina, October 1-5, 2015. See figure 3 for location. 


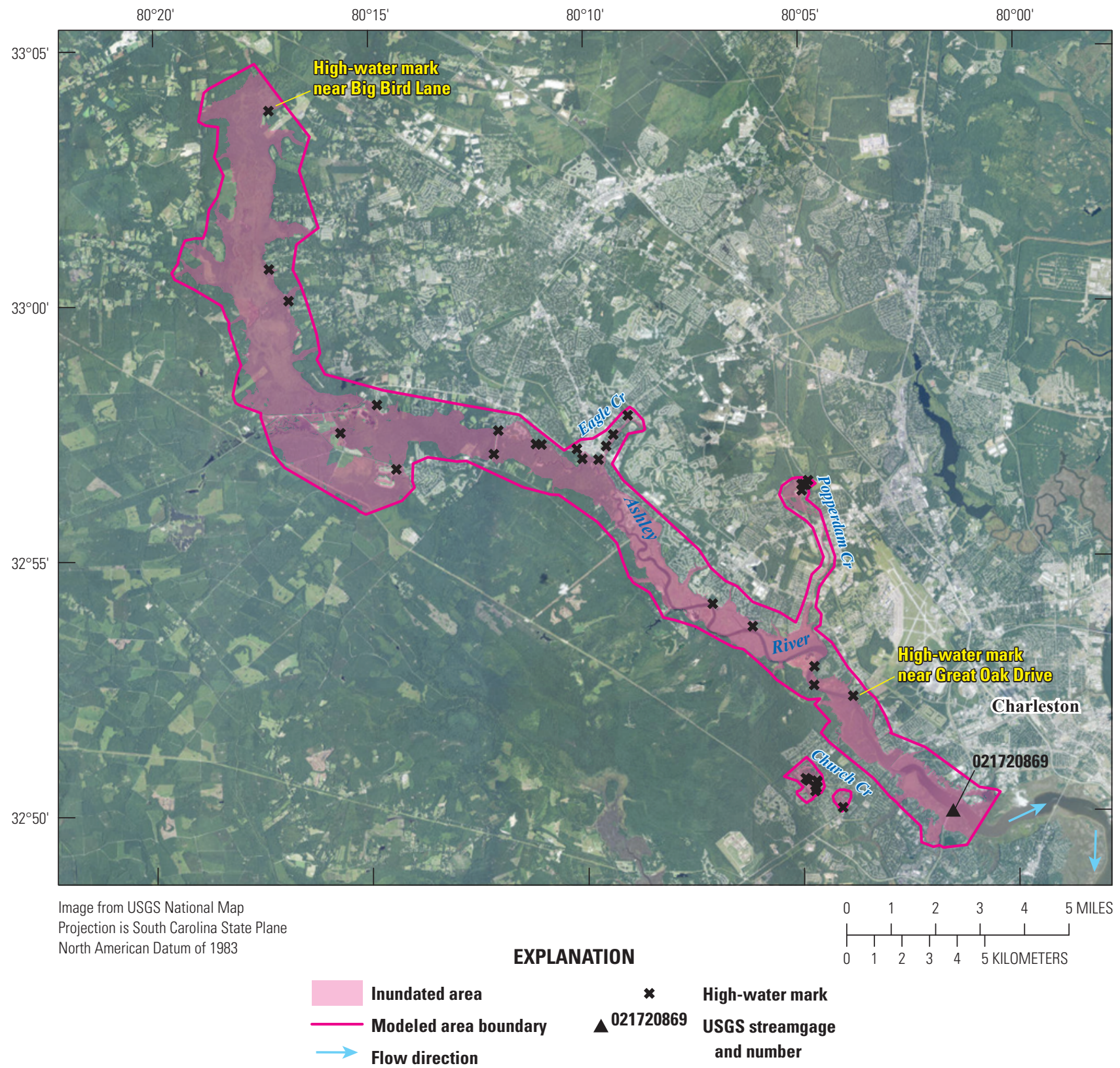

Figure 2-2. Flood-inundation map of the Ashley River near Charleston, South Carolina, October 1-5, 2015. See figure 3 for location. 


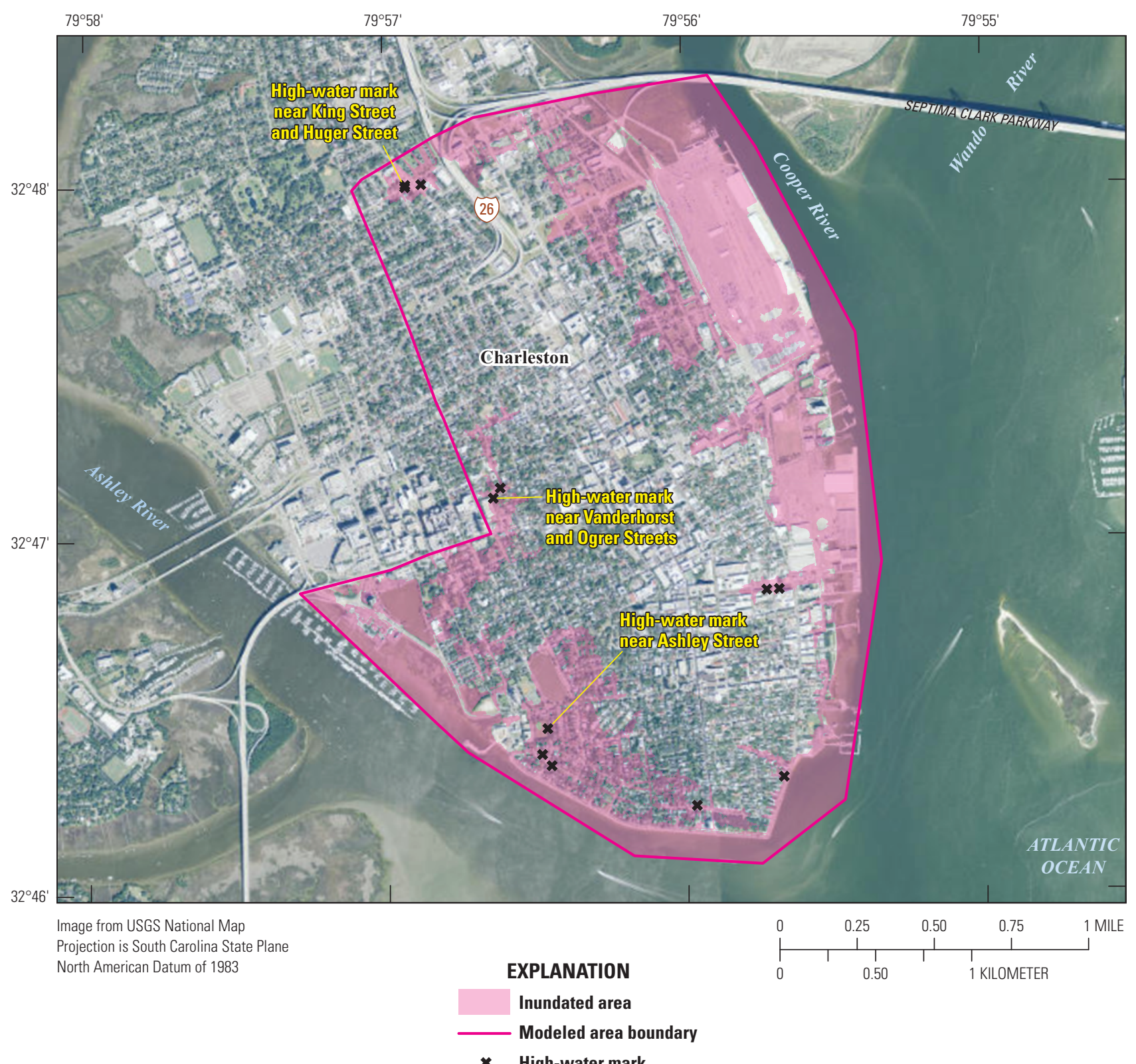

Figure 2-3. Flood-inundation map of coastal Charleston, South Carolina, October 1-5, 2015. See figure 3 for location. 


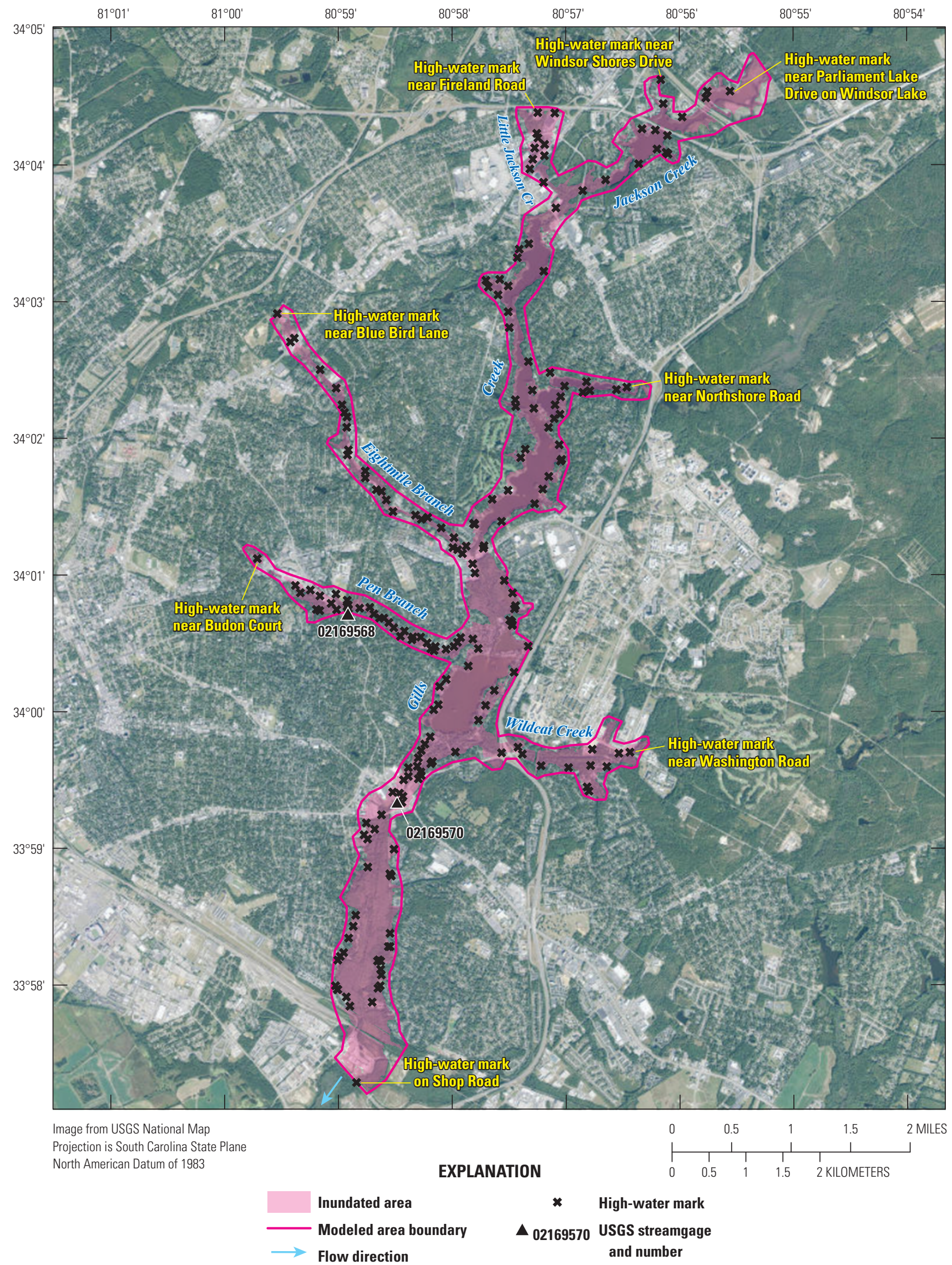

Figure 2-4. Flood-inundation map of Gills Creek in Columbia, South Carolina, October 1-5, 2015. See figure 3 for location. 
$81^{\circ} 10^{\prime}$

$81^{\circ} 09^{\prime}$

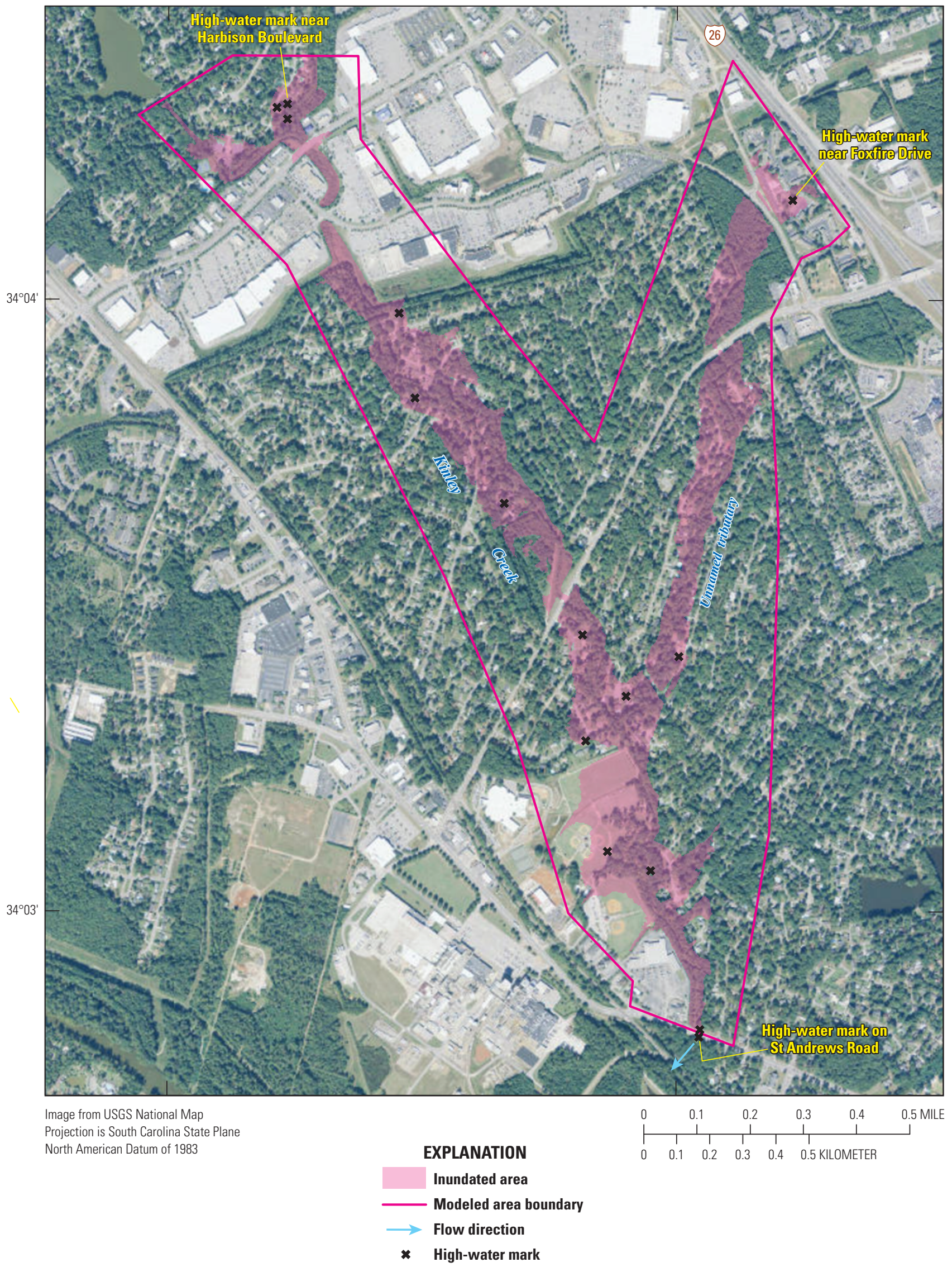

Figure 2-5. Flood-inundation map of Kinley Creek near Columbia, South Carolina, October 1-5, 2015. See figure 3 for location. 


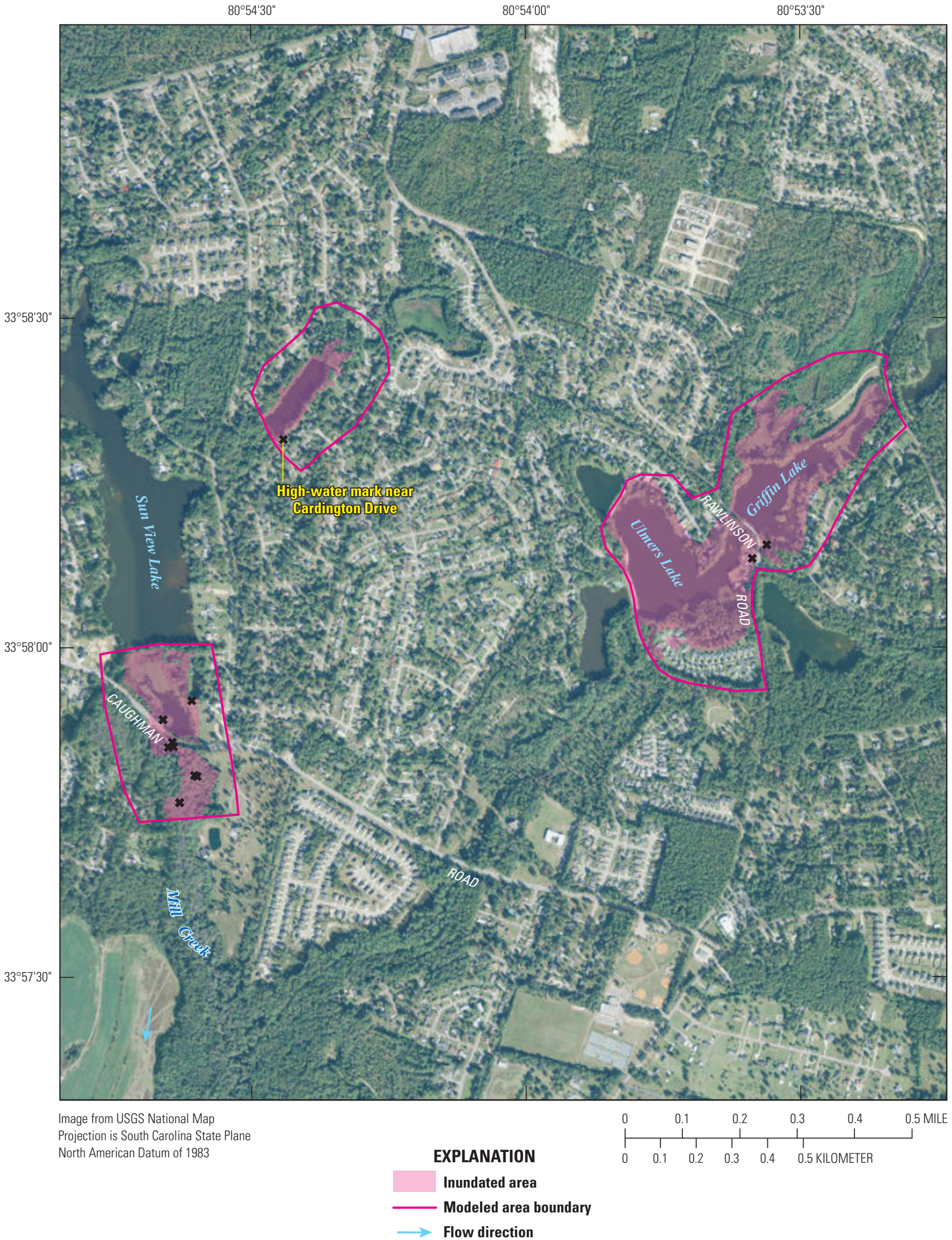

* High-water mark

Figure 2-6. Flood-inundation map of Mill Creek near Columbia, South Carolina, October 1-5, 2015. See figure 3 for location. 


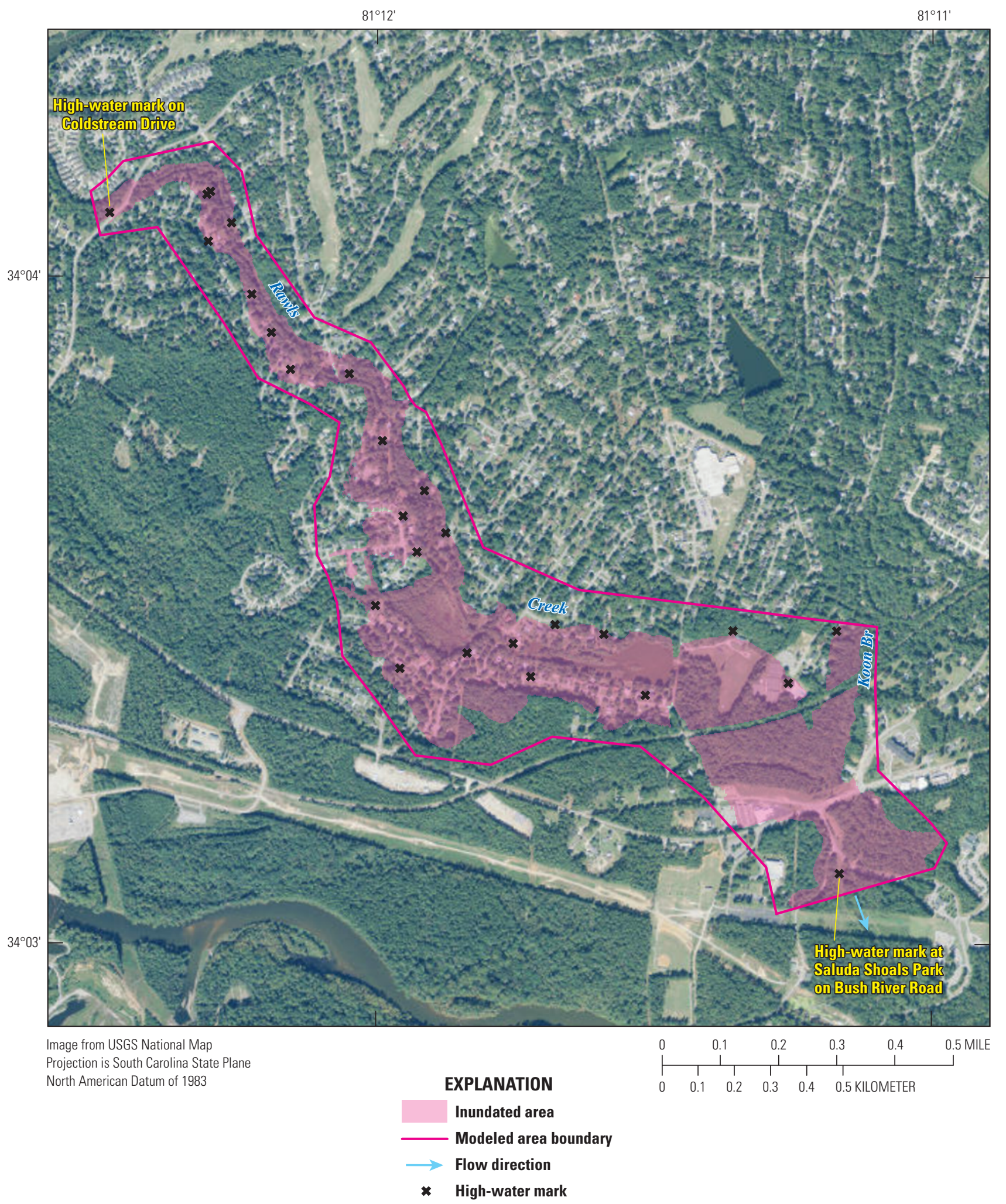

Figure 2-7. Flood-inundation map of Rawls Creek near Columbia, South Carolina, October 1-5, 2015. See figure 3 for location. 


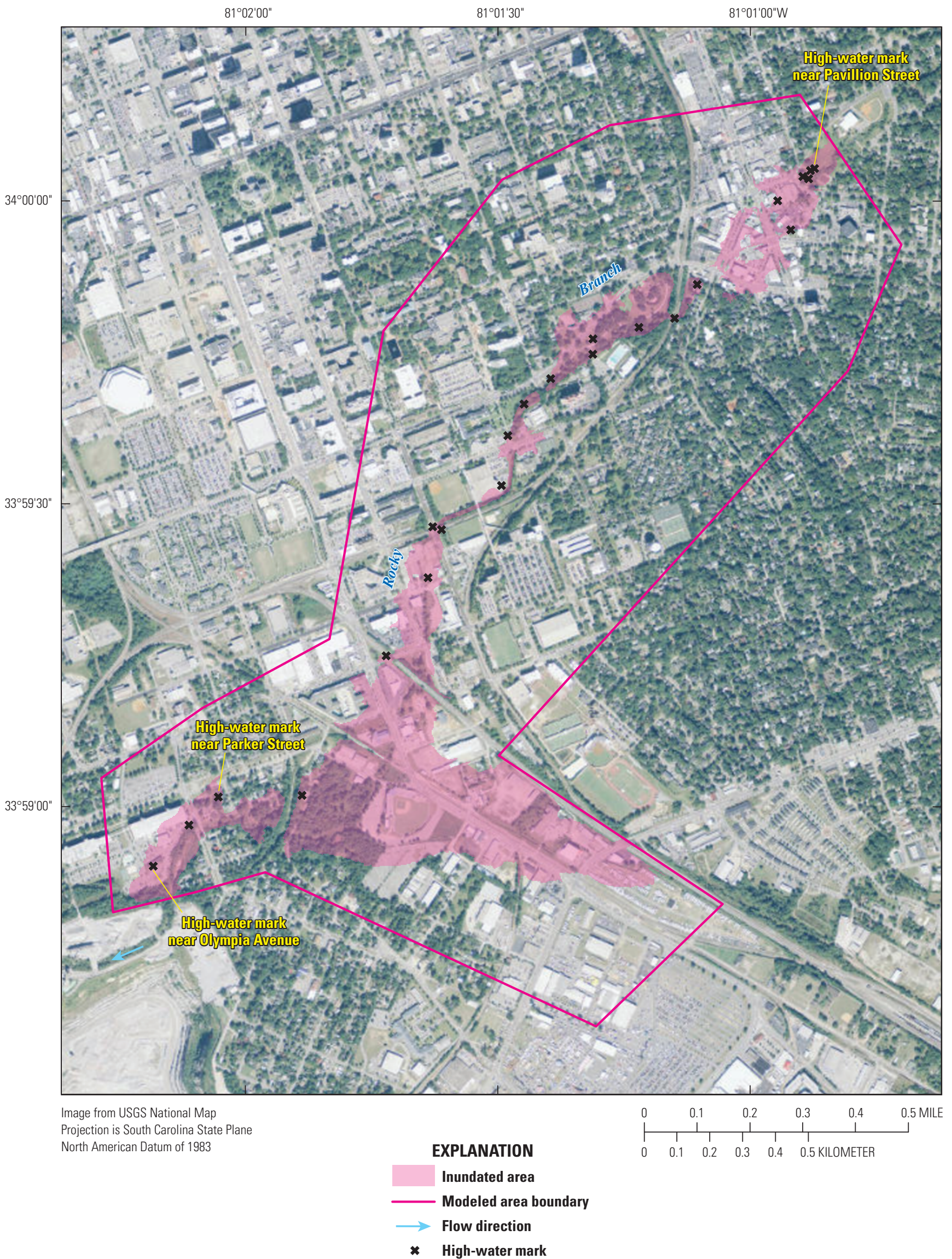

Figure 2-8. Flood-inundation map of Rocky Branch in Columbia, South Carolina, October 1-5, 2015. See figure 3 for location. 


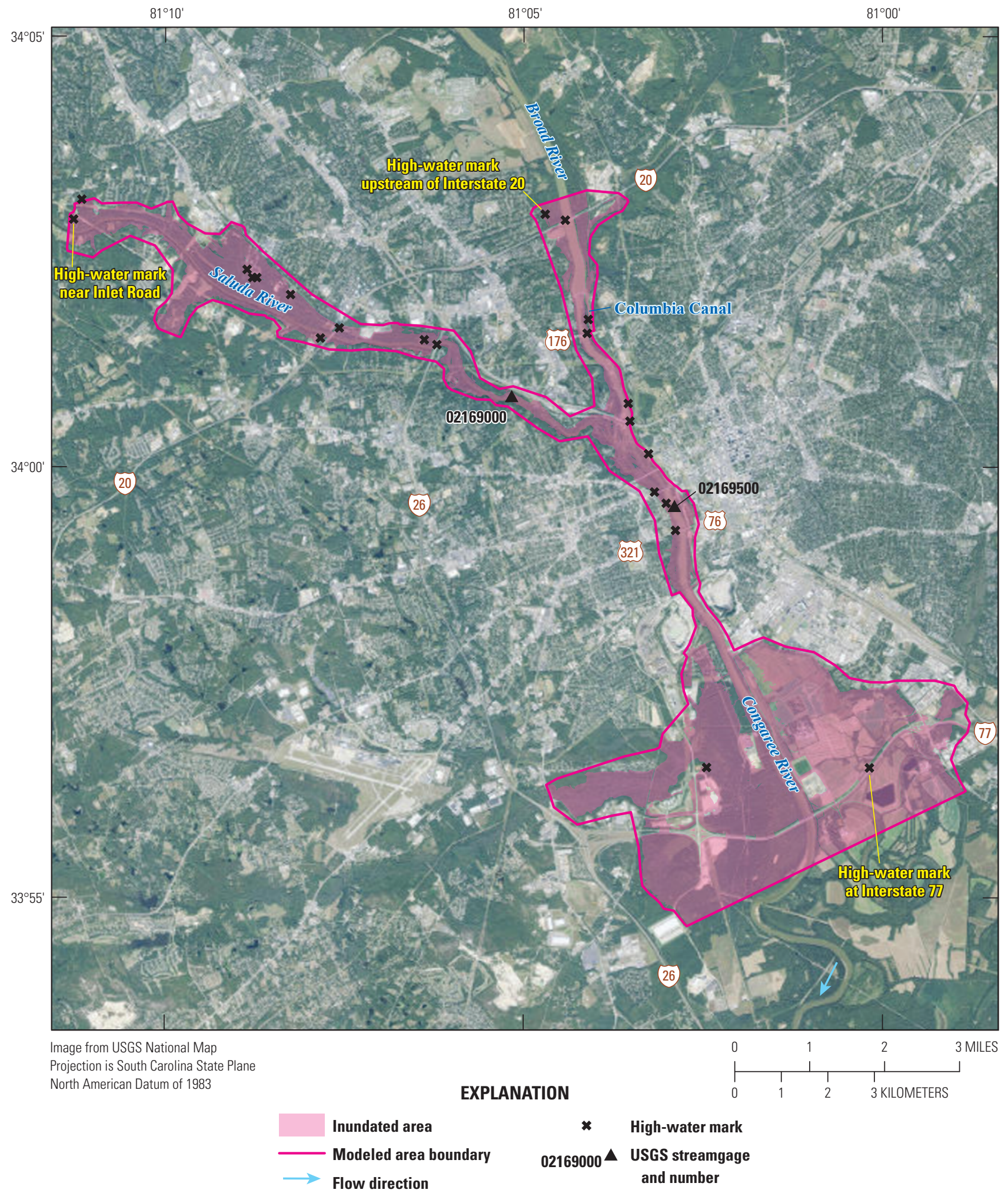

Figure 2-9. Flood-inundation map of Saluda, Broad, and Congaree Rivers near Columbia, South Carolina, October 1-5, 2015. See figure 3 for location. 


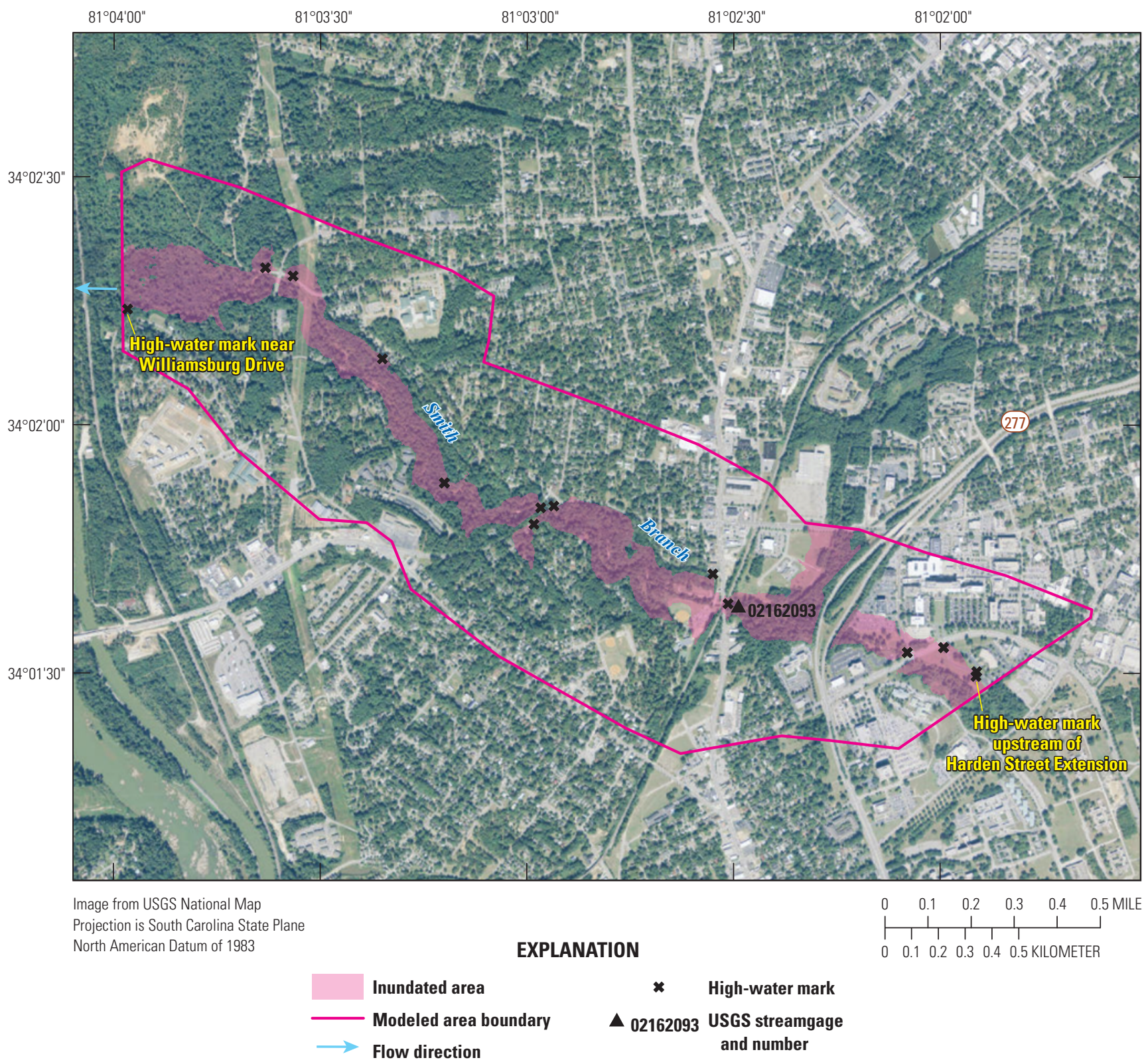

Figure 2-10. Flood-inundation map of Smith Branch in Columbia, South Carolina, October 1-5, 2015. See figure 3 for location. 


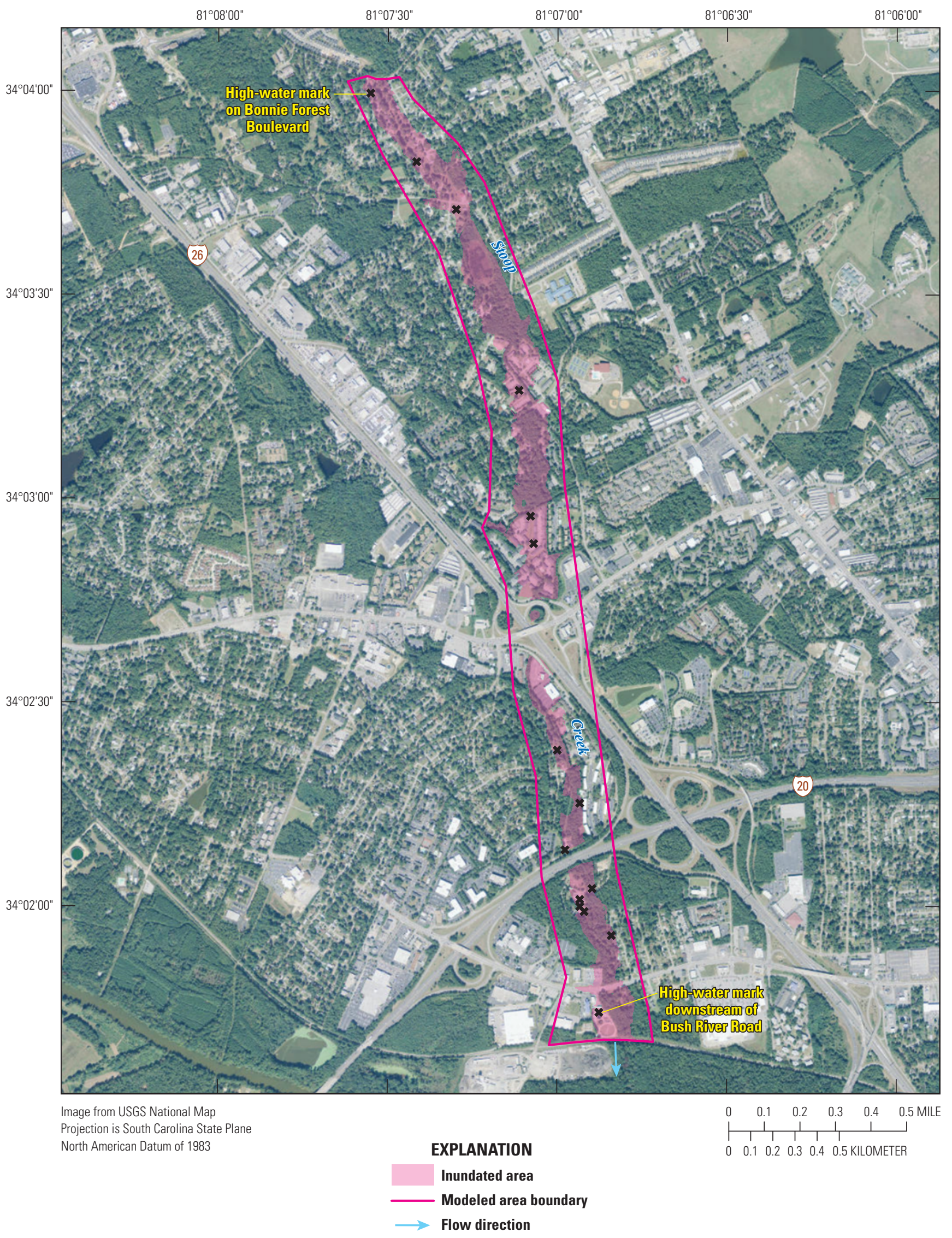

* High-water mark

Figure 2-11. Flood-inundation map of Stoop Creek near Columbia, South Carolina, October 1-5, 2015. See figure 3 for location. 


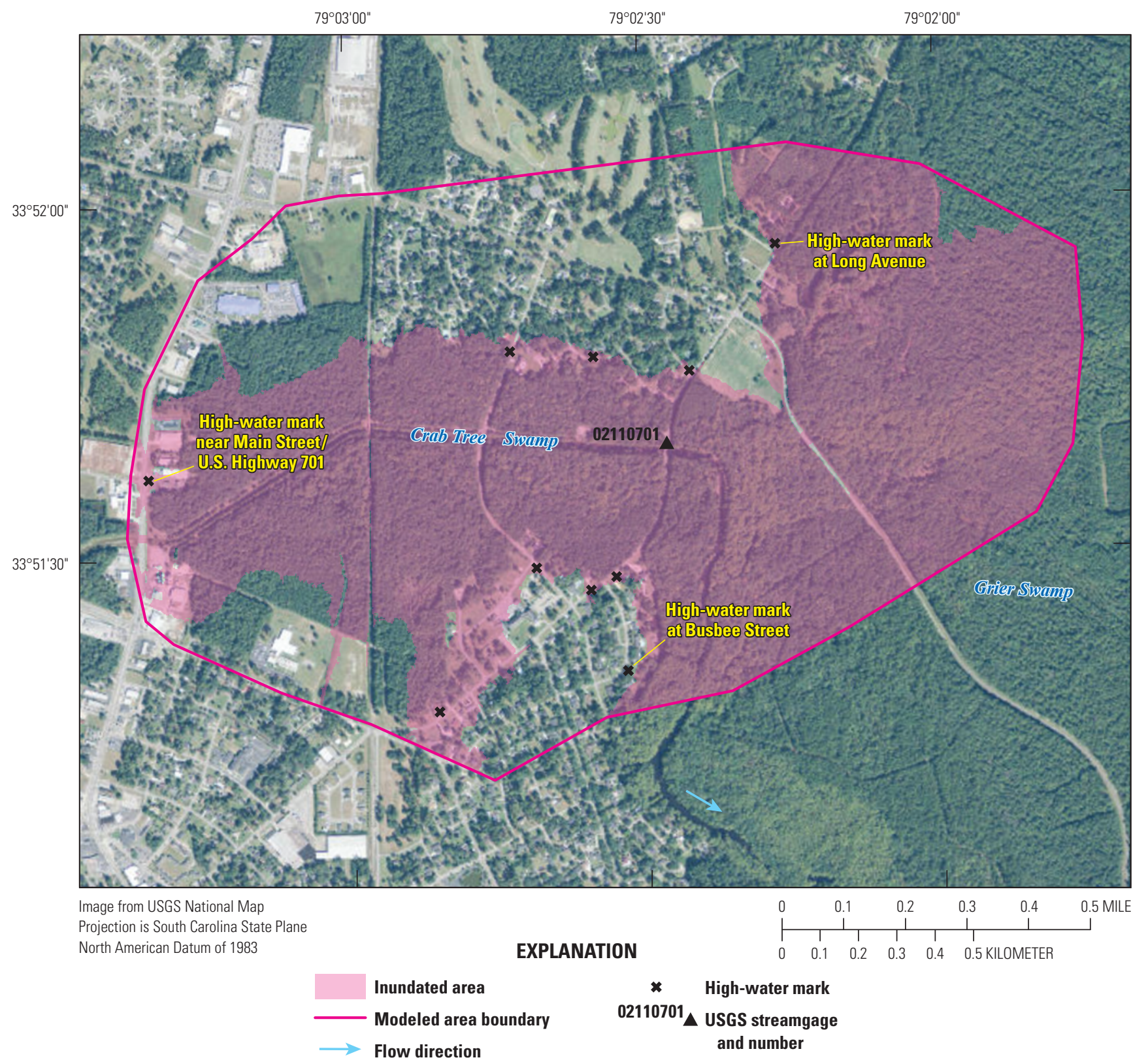

Figure 2-12. Flood-inundation map of Crab Tree Swamp at Conway, South Carolina, October 1-5, 2015. See figure 3 for location. 


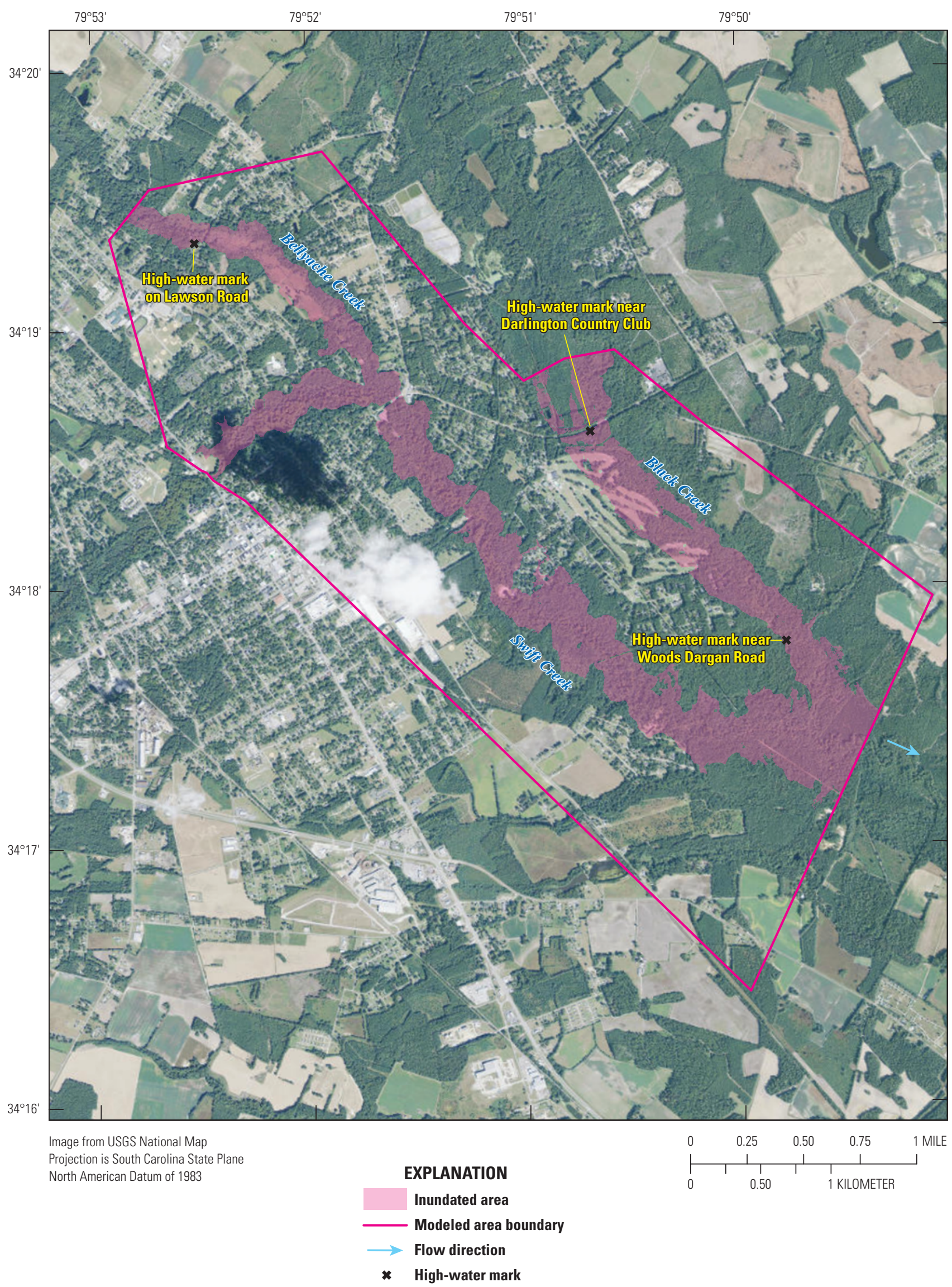

Figure 2-13. Flood-inundation map of Black Creek at Darlington, South Carolina, October 1-5, 2015. See figure 3 for location. 


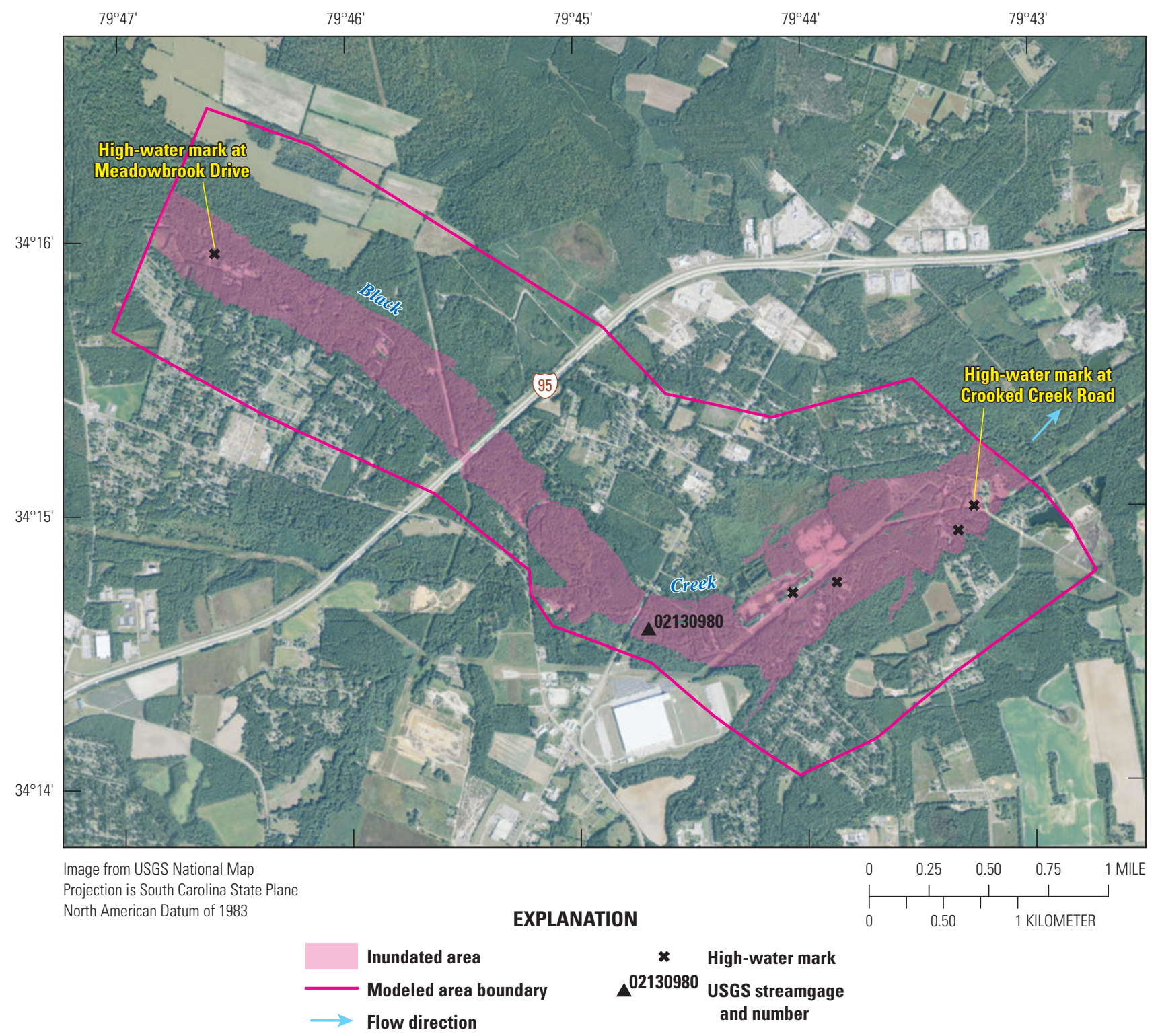

Figure 2-14. Flood-inundation map of Black Creek at Florence, South Carolina, October 1-5, 2015. See figure 3 for location. 


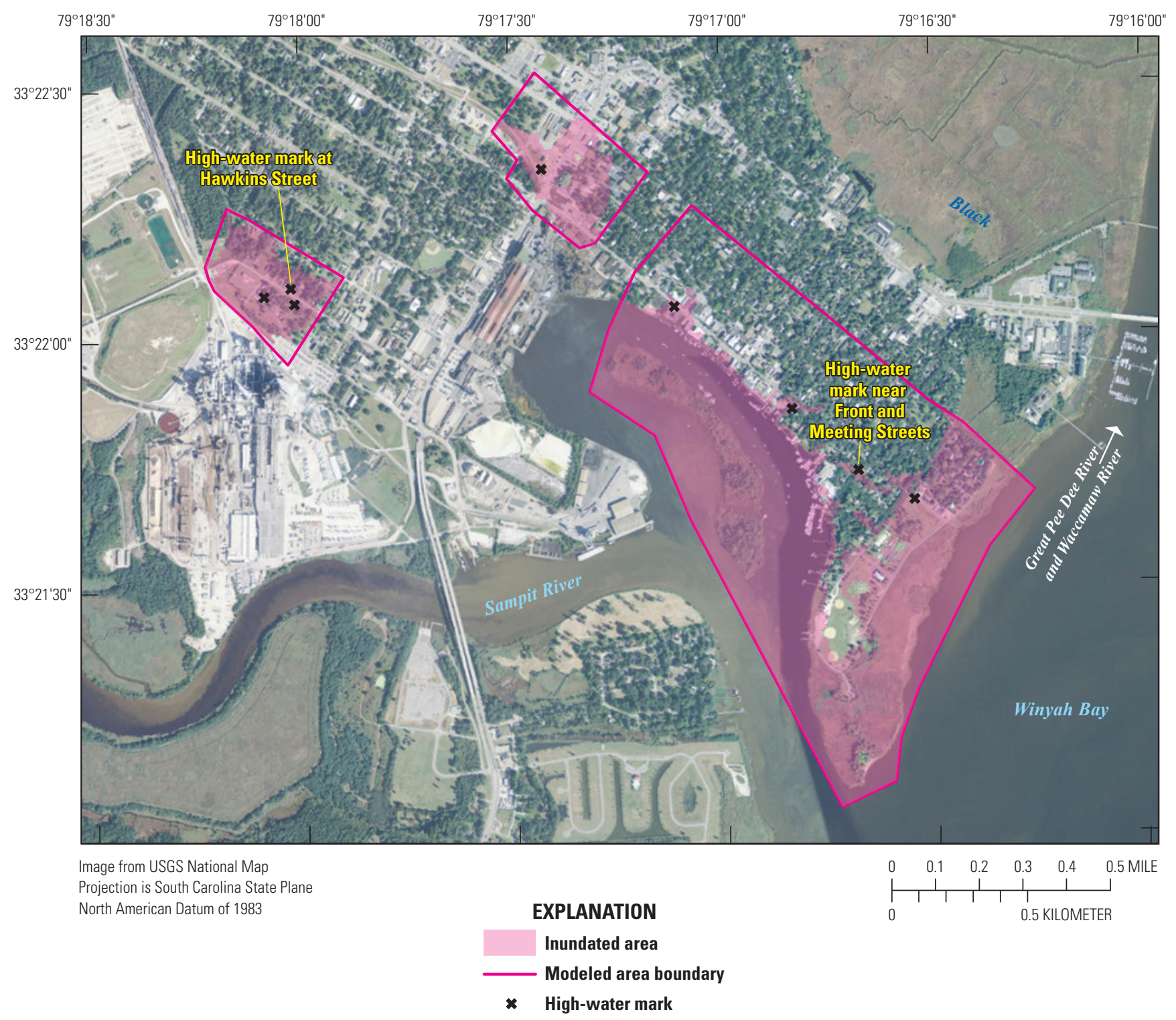

Figure 2-15. Flood-inundation map of coastal Georgetown, South Carolina, October 1-5, 2015. See figure 3 for location. 


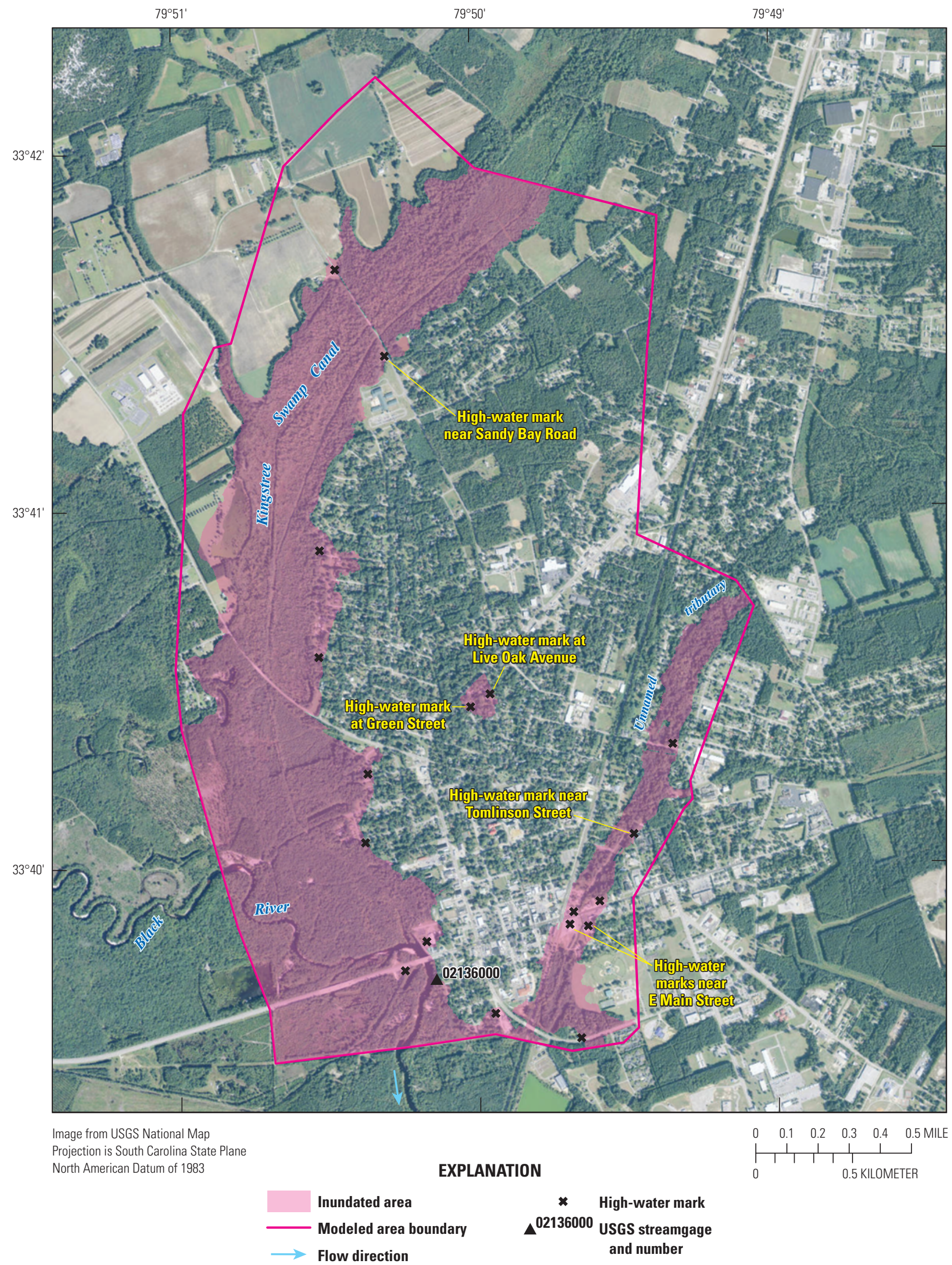

Figure 2-16. Flood-inundation map of Black River at Kingstree, South Carolina, October 1-5, 2015. See figure 3 for location. 
$80^{\circ} 15^{\prime}$

$80^{\circ} 14^{\prime}$

$80^{\circ} 13^{\prime}$

$80^{\circ} 12^{\prime}$

$80^{\circ} 11^{\prime}$

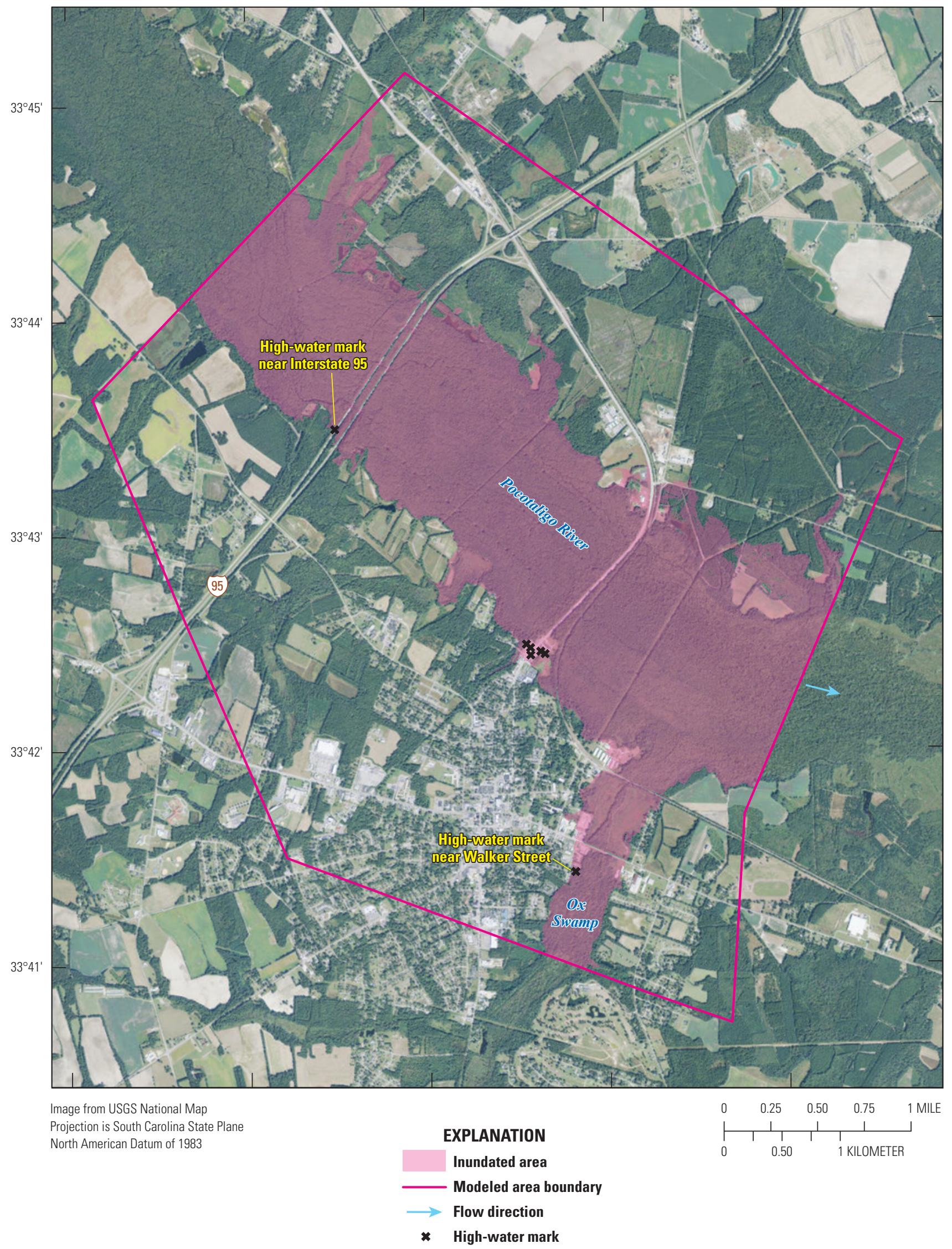

Figure 2-17. Flood-inundation map of the Pocotaligo River at Manning, South Carolina, October 1-5, 2015. See figure 3 for location. 


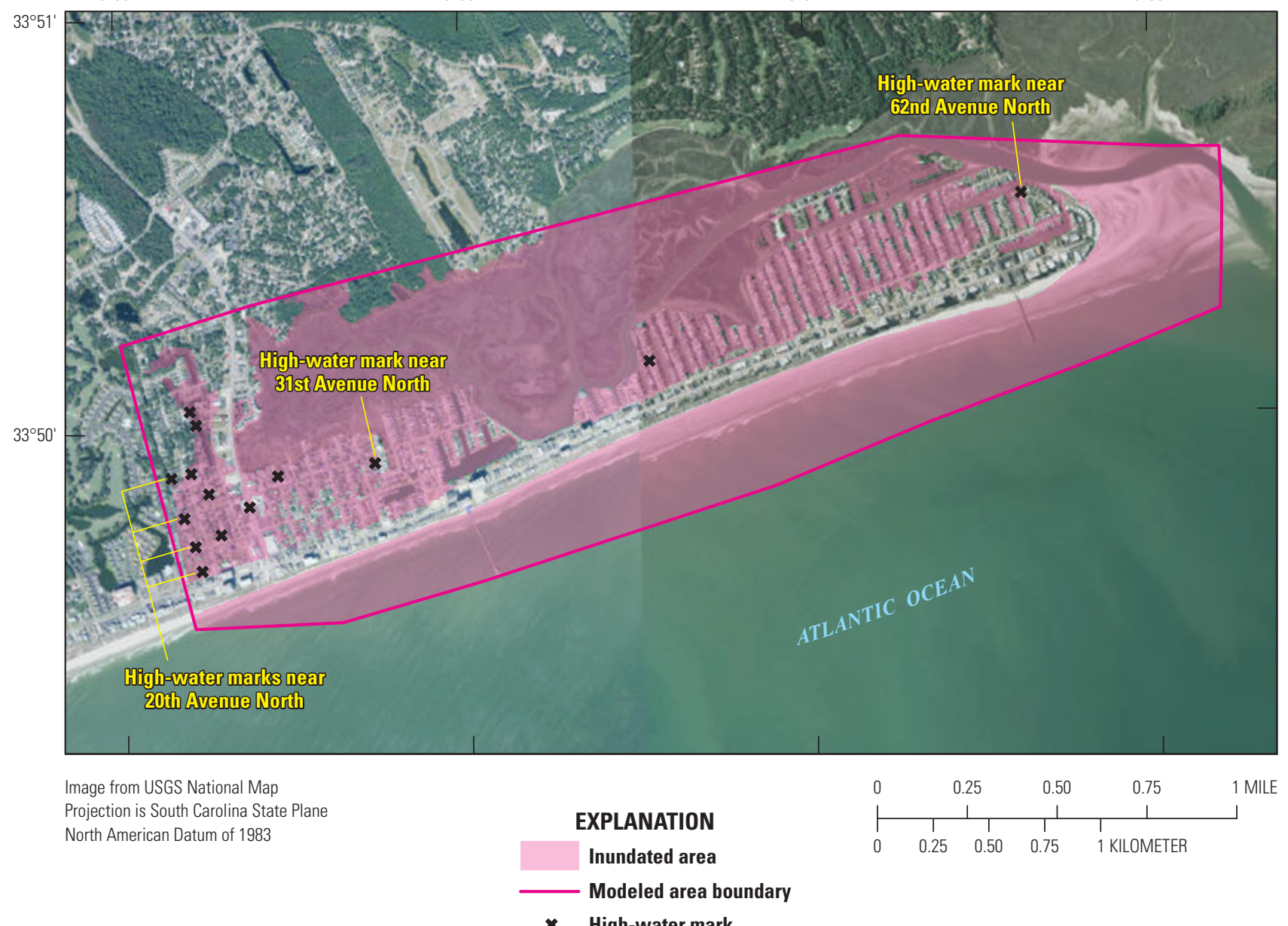

Figure 2-18. Flood-inundation map of coastal North Myrtle Beach, South Carolina, October 1-5, 2015. See figure 3 for location. 


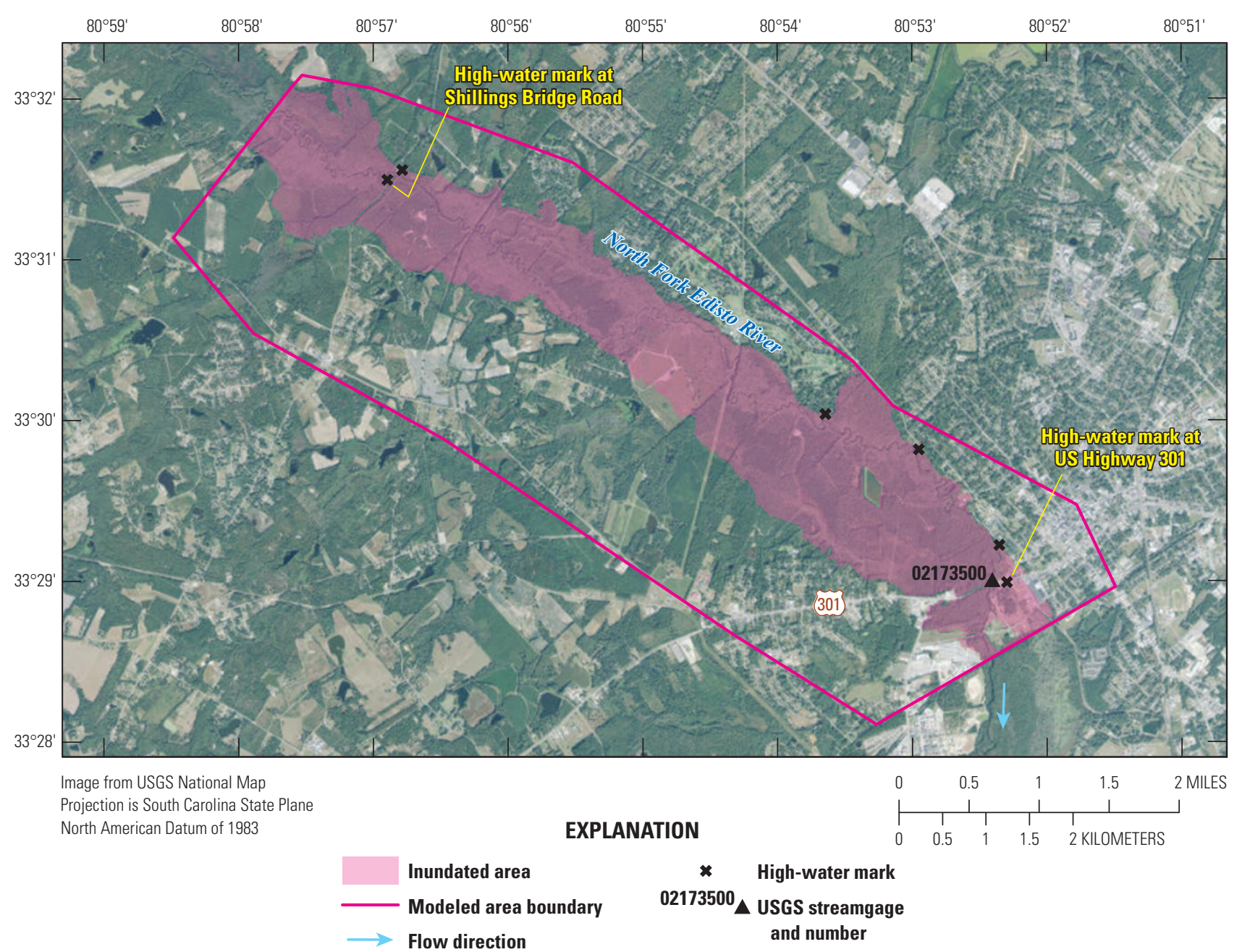

Figure 2-19. Flood-inundation map of the North Fork Edisto River at Orangeburg, South Carolina, October 1-5, 2015. See figure 3 for location. 


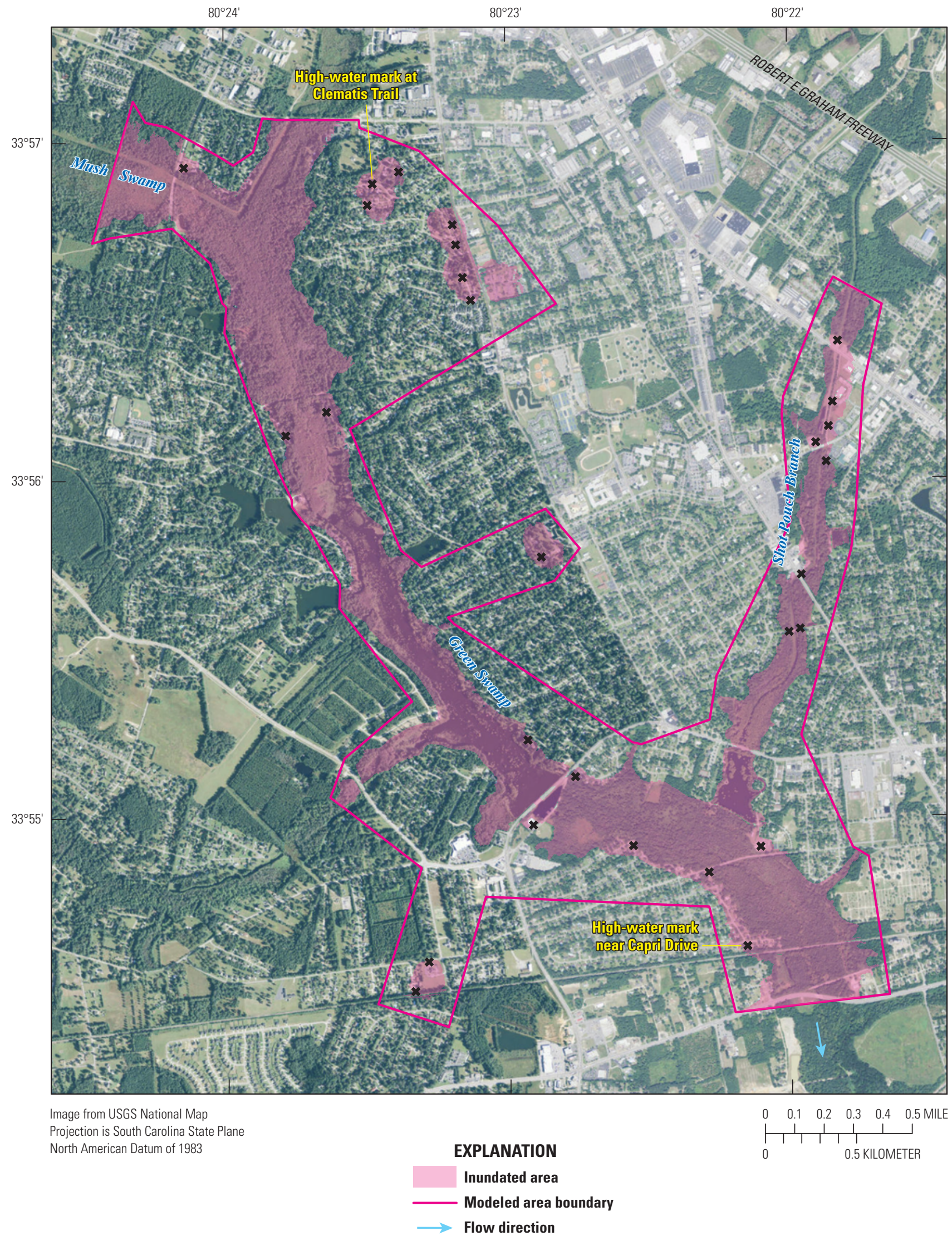

* High-water mark

Figure 2-20. Flood-inundation map of Green Swamp near Sumter, South Carolina, October 1-5, 2015. See figure 3 for location. 

Manuscript approved on February 12, 2016

Prepared by the USGS Science Publishing Network Raleigh Publishing Service Center

Edited by Kay P. Naugle Illustrations and layout by Caryl J. Wipperfurth

For more information about this publication contact: Director, South Atlantic Water Science Center U.S. Geological Survey 720 Gracern Road Columbia, SC 29210 http://www.usgs.gov/water/southatlantic/ 
